\title{
Mobile-assisted and gamification-based language learning: a systematic literature review
}

\author{
Kashif Ishaq $^{1}$, Nor Azan Mat Zin ${ }^{1}$, Fadhilah Rosdi ${ }^{1}$, Muhammad Jehanghir ${ }^{2}$, Samia Ishaq ${ }^{3}$, Adnan Abid ${ }^{\text {Corresp. } 4}$ \\ 1 Faculty of Information Science and Technology, Universiti Kebangsaan Malaysia, Bangi, Malaysia \\ 2 Institute of Education and Research, University of the Punjab, Lahore, Punjab, Pakistan \\ 3 School Education Department, Sheikhupura, Pakistan \\ 4 Department of Computer Science, University of Management \& Technology, Lahore, Lahore, Pakistan \\ Corresponding Author: Adnan Abid \\ Email address: adnanabid7@gmail.com
}

Learning a new language is a challenging task. In many countries, students are encouraged to learn an international language at school level. Particularly English is the most widely used international language and being taught at the school level in many countries. The ubiquity and accessibility of smartphones combined with the recent developments in mobile application and gamification in teaching and training have paved the way for experimenting with language learning using mobile phones. This article presents a systematic literature review of the published research work in mobile-assisted language learning. To this end, more than 60 relevant primary studies which have been published in well-reputed venues have been selected for further analysis. The detailed analysis reveals that researchers developed many different simple and gamified mobile applications for learning languages based on various theories, frameworks, and advanced tools. Furthermore, the study also analyses how different applications have been evaluated and tested at different educational levels using different experimental settings while incorporating a variety of evaluation measures. Lastly, a taxonomy has been proposed for the research work in mobile-assisted language learning, which is followed by promising future research challenges in this domain. 


\title{
1 Mobile-Assisted and Gamification-based Language 2 Learning: A Systematic Literature Review
}

3

4

\author{
Kashif Ishaq ${ }^{1}$, Nor Azan Mat Zin ${ }^{2}$, Fadhilah Rosdi ${ }^{3}$, Muhammad Jehanghir ${ }^{4}$, Samia Ishaq ${ }^{5}$, \\ Adnan Abid 6 \\ ${ }^{1}$ Faculty of Information Science and Technology, Universiti Kebangsaan Malaysia, Bangi, Malaysia \\ ${ }^{2}$ Faculty of Information Science and Technology, Universiti Kebangsaan Malaysia, Bangi, Malaysia \\ ${ }^{3}$ Faculty of Information Science and Technology, Universiti Kebangsaan Malaysia, Bangi, Malaysia \\ ${ }^{4}$ Institute of Education and Research, University of the Punjab, Lahore, Pakistan \\ ${ }^{5}$ School Education Department, Sheikhupura, Pakistan \\ ${ }^{6}$ Department of Computer Science, University of Management and Technology, Lahore, Pakistan \\ Corresponding Author: \\ Adnan Abid \\ Department of Computer Science, University of Management and Technology, Lahore, Pakistan \\ E-mail address: adnanabid7@gmail.com
}

\section{ABSTRACT:}

Learning a new language is a challenging task. In many countries, students are encouraged to learn an international language at school level. Particularly English is the most widely used international language and being taught at the school level in many countries. The ubiquity and accessibility of smartphones combined with the recent developments in mobile application and gamification in teaching and training have paved the way for experimenting with language learning using mobile phones. This article presents a systematic literature review of the published research work in mobile-assisted language learning. To this end, more than 60 relevant primary studies which have been published in well-reputed venues have been selected for further analysis. The detailed analysis reveals that researchers developed many different simple and gamified mobile applications for learning languages based on various theories, frameworks, and advanced tools. Furthermore, the study also analyses how different applications have been evaluated and tested at different educational levels using different experimental settings while incorporating a variety of evaluation measures. Lastly, a taxonomy has been proposed for the research work in mobile-assisted language learning, which is followed by promising future research challenges in this domain.

Keywords: Language Learning, Mobile Assisted Learning, M-Learning, Gamification, Educational Technology

\section{INTRODUCTION}

Mobile technology developments are quickly expanding the field of learning in non-formal education areas by rendering universal and instance-oriented access to privileged digital 
41

42

43

44

45

46

47

48

49

50

51

52

53

54

55

56

57

58

59

60

61

62

63

64

65

66

67

68

69

70

resources [1]. Mobile learning (m-learning) technology requires mobile devices to improve learning and academic performance by having the opportunity to learn remotely at all times in compliance with students' comforts. There have been many advantages to m-learning, including cost reductions, ubiquitous communication, research assistance, and location-based services. The goal of m-learning is to put the educational sector and associations at the center of academic progress to satisfy the users' demand for flexibility and ubiquity [63]. Mobile devices are mostly used in developed countries, particularly for language learning purposes. Specifically, MobileAssisted Language Learning (MALL) implies mobile phones in the learning and teaching of languages. The mobile phone allows pupils to learn quickly to develop their language comprehension skills. Besides, a significant improvement in pedagogical methods was brought about by integrating smartphone apps and games with the curriculum, thus enabling the students to learn freely in time, space and motivation on an individual basis [62].

A significant trend in mobile learning apps development involves gamification concepts that incorporates play and fun elements to inspire and attract the learner, generally referred to as serious games. A serious game's key objective is to accomplish a learning objective in a fun mode, whereby the locus of control is with the learner [5]. Currently, schooling is not limited to a single life stage and not exclusively in traditional education institutions. Children should not only study at school but also informally outside of school. Their casual reactions outside of the classroom provide an almost as valuable learning experience as the classrooms' organized learning environment. The integration of multimedia learning content enables learners to access appropriate information within and outside the school [5].

The previous review studies in the MALL domain mostly concentrated on technology-based learning and handheld devices, while less on the research frameworks, content, learning, and teaching resources, as shown in Table 1. This table compares current measures based on five essential viewpoints: targeted digital repositories, teaching and learning methods, quality assessment evaluation, research framework, and learning material. Only quality articles were reviewed published in quality journals (except workshops and seminars) and performed quality assessments by discussing research frameworks, content, and teaching and learning tools. This article was structured as follows: Section II presented a review of relevant literature. Section III presented the methodology adopted to perform this study, along with questions and objectives. Whereas Section IV identified and summarized answers to specific study questions. Section $\mathrm{V}$ presented a blend of the discussed research by defining its taxonomy, while Section VI concluded this article.

\section{LITERATURE REVIEW:}

Most of the surveys and systematically reviewed on MALL do not cover publication channels (Books or Scientific Journals), quality assessment, frameworks/model used, mobile and gamified applications used for teaching and learning, and comparison of these applications. Also, the focus was more on higher education students than on primary education. A more recent systematic review on the usage of mobile devices for language learning evaluated limited studies and from restricted repositories [68] [69]. The author reviewed 20 studies for mobile devices' effect on students' achievement in which student's vocabulary learning results using handheld devices were compared to those using conventional learning [69].

In another study, the effects of embedded portable devices in learning and teaching were examined by reviewing 110 experimental and quasi-experimental journal papers published in 
87 1993-2013. For the usage of mobile devices in school, a moderate mean efficiency was 0.523.

88 Sung et al. [64] analyzed the impact size of moderators and the benefits and drawbacks of mobile

89 learning, then synthesized based on the descriptive analysis from individual experiments at

90 various levels of moderator variables. Another SLR of researches from 2007 to the present was

91 on mobile education in K-12 in which [66] reviewed a maximum of 63 articles from 15 journals,

92 mostly exploratory and concentrated on the educational facilities associated with smartphone

93 usage in learning. Furthermore, patterns and critical problems are also discussed for future

94 research. Burston [67] summarized 345 MALL research studies from 1994 to 2012, in a short

95 overview of 80 words, to encourage researchers by presenting their historical background. The

96 analysis included the home country, first or second or foreign language, the technologies

97 employed for mobile apps, targeted research areas, type of students, demographic, study time,

98 and the outcome summary.

99 Finally, [65] targeted influential journals from 2001 to 2010 to investigate mobile and ubiquitous

100 learning researches related to enhanced learning technology. The publications included

101 Educational Technology \& Society, Innovations in Education and Teaching

102 International, Journal of Computer Assisted Learning, Computers and Education, Educational

103 Technology Research \& Development, and British Education Technology Journal. The

104 researcher presented information for many journals, a selected search sample (primary school,

105 secondary school, tertiary education, instructors and employees), study fields (language and arts,

106 engineering, science, math, social sciences, and more), and countries involved. However, none

107 focused on quality assessment, framework/models, grade or education level, adopted content,

108 approaches, statistical analyses, and comparisons between MALL and gamified apps. In our

109 review, both areas were thoroughly discussed and differentiated from the above studies then

110 systematically chose methods and coded them with standard naming, according to strict

111 guidelines.

112 This Systematic Literature Review (SLR) discusses MALL - learners in-depth, mobile, and

113 game-based languages, and involves the five perspectives as in Table 1. Based on the structural

114 analysis criteria, 67 research articles have been finalized and assessed in quantitative and

115 qualitative terms for further analysis. The SLR's significance presents the new classification

116 criteria, MALL research trends, developed/adopted research models, learning and

117 teaching methods, learning content, comparisons of mobile and game-based apps, research

118 methodologies, and approaches used to evaluate the studies. This SLR may allow instructors

119 to build a standardized MALL environment with learning and teaching apps, learning materials,

120 frameworks, and relevant methodologies.

121 The study of [64] chose experimental and quasi-experimental journal articles from the period

122 1993-2013 from ERIC and SSCI repositories (only eight journals were selected) to know the use

123 of mobile experimental studies of teaching and learning achievement of students through these

124 devices. The study [65] published in 2011, in which journal articles were selected from SSCI

125 repository of the 2001-2010 period to know the status of mobile and ubiquitous learning, as well

126 as research sample group along with learning domains related to technology, were adopted in

127 selected articles. In the study of [66], the selected articles were taken from 2007 to 2012 for

128 teaching and learning of K-12 education. The study aimed to know the effectiveness and trends

129 of mobile devices in K-12 education, and the participants were younger than 18 years.

130 The study of [67] selected the studies from the period of 1994 to 2012 in the area of MALL and

131 annotation in which only 80 words summary was provided consisted of country, native language,

132 mobile technology used, learning area, type of learners, and numbers, and an overview of results. 
133 The study [68] examined the effect of vocabulary learning using mobile devices by selecting 16

134 studies from ERIC, IEEE Xplore, IGI, Sage, ScienceDirect, and Springer. The study [69]

135 finalized 20 studies to see the effect of mobile devices in language learning on students'

136 achievement, and ERIC, EBSCOhost, JSTOR, and ProQuest repositories were filtered for the

137 literature search. This systematic literature review aims to explore the Web of Science core

138 collection for high-quality literature search to know the research trends of Mobile and

139 Gamification based language learning. Moreover, a quality assessment of the selected articles

140 was conducted along with the discussion of research frameworks/models and teaching and

141 learning tools at all education levels.

142

143 III. RESEARCH METHODOLOGY:

144 This survey implemented recommendations for systematic reviews given in information

145 engineering analysis by [70]. Based on these criteria, a search method was defined to eliminate

146 possible study biases after finalizing research queries. Within this procedure, three critical phases

147 of our analysis approach were to prepare, conduct, and review the study, as shown in Figure 1

148 and discussed in the following sections.

149

150

151

152

153

154

155

156

157

158

159

160

161

162

163

164

165

166

167

\section{A. REVIEW PLAN}

An appropriate search strategy was created for all related studies. As shown in Figure 1 and Figure 2, the analysis methods indicate search procedures for the associated articles, describing the classification system and mapping of items. This study follows an organized approach:

- Research objectives

- Specifying research questions (RQs)

- Organizing searches of databases

- Studies selection

- Screening relevant studies

- Data extraction

- Results synthesizing

- Finalizing the review report

i) RQ1 attempted to report our objective to develop an articles' library related to the MALL pupils and make the dataset accessible to other scholars. Furthermore, significant work was identified that provided direction to investigate students' issues in learning English. The answer to RQ1 discovered trends, geographical areas, and publication channels in the articles.

ii) To identify the theories and frameworks/conceptual models used for MALL research and relate them with one another and to different application areas for MALL. The solution of RQ2 provided the answer to this objective.

iii) RQ3 attempted to identify different target application areas of MALL from teaching and learning perspectives. Furthermore, other modes of exposition were identified for these MALL applications.

iv) How the researchers accommodated different MALL applications content focusing on

175 reading, writing, speaking, and listening perspectives. For this purpose, RQ4 attempted to

176 achieve this objective. 
177 v) RQ5 attempted to outline the standard process, tools, and instruments used to evaluate MALL 178 applications. Furthermore, MALL applications' evaluation measures were identified concerning

179 different perspectives, including teaching and learning, and technical perspectives.

180 vi) RQ6 attempted to perform a comparative analysis to evaluate the effectiveness of simple 181 mobile application-based language learning with gamified mobile applications for language 182 learning.

The research objectives and motivations of this research are transformed into relevant research questions (RQ), as shown in Table 2.

\section{B. REVIEW CONDUCT}

There were four steps in the review process formulated. In the first step, examination was made from web of science [71] with SCI-Expended, SCIE, ESCI, and A\&HCI indices consisting of high-impact research papers, for relevant primary studies. In the second step, the collection of studies was filtered based on predefined inclusion/exclusion criteria. We also established quality assessment standards to boost further the consistency in the third step of our analysis. Backward snowballing was then carried out in the final fourth step, to retrieve relevant candidate articles.

\section{i. AUTOMATED SEARCH IN WEB OF SCIENCE (WoS Core Collection)}

A systematic investigation was made to filter irrelevant research and obtain adequate information. Our source was a curated database, Web of Science Core library that included over 21,100 peer-reviewed journals, top-class academic journals distributed worldwide (including Open Access journals), covering more than 250 disciplines [71]. WoS is a tool that helps users collect, interpret, and share information from databases promptly [72]. To conduct an SLR in an organized and timely manner, the researcher used this platform to retrieve the research articles by incorporating 'AND' and 'OR' Boolean operators with keywords to develop a search string.

205 Figure 3 presented an overview of the search result obtained from the Web of Science.

Table 3 lists the final search string incorporated 'AND' and 'OR' Boolean operators with keywords, used to explore WoS Core Collection. Only titles were searched from the database, and a filter of indices and period were applied to restrict the search query for the study.

209

210

211

212

213

214

215

216

217

\section{ii. SELECTION BASED ON INCLUSION/EXCLUSION CRITERIA}

\section{Inclusion criteria:}

The paper comprised in the review must be in MALL, mobile learning, and m-learning that must target the research questions. Paper published in the journals or conferences also from 2010 to 2020 was included in the review. Papers discussing MALL at school, college, and university level, focusing on learning, teaching, learning, and teaching (both), games (Example: Serious Game, Mobile games, learning application) were also included in the review.

\section{Exclusion criteria}


219 The articles were excluded not written in English and did not discuss or focused MALL, mobile

220 learning or m-learning in schools, colleges, and universities to teach and learn English. A

221 selection process of relevant articles for inclusion/exclusion criteria in detail was shown in

222 Figure 4.

223

224

225

226

227

228

229

230

231

232

233

234

235

236

237

238

239

240

241

242

243

244

245

246

247

248

249

250

251

252

253

254

255

256

257

258

259

260

261

262

263

264

\section{iii. SELECTION BASED ON QUALITY ASSESSMENT}

The collection of appropriate studies based on quality assessment (QA) was considered the critical step for carrying out any review. As the fundamental studies differed in nature, the essential assessment tool [73] and [74] used to conduct QA were also supplemented in our analysis by quantitative, qualitative, and mixed approaches. The accuracy of the selected records was determined using a QA questionnaire. The first author conducted the QA, using the following parameters for each study:

a) If the analysis led to MALL, mobile language learning, m-learning, the result was indeed (1), otherwise (0).

b) When there were simple answers for the MALL, mobile learning, m-learning of English, the analysis provided the following scores: 'Yes (2), 'Limited (1)' and 'No (0).'

c) If the studies provided an empirical result, then award (1) else score (0).

d) Studies analyzed concerning graded rankings of countries and journals [75] and conferences in computer science [76]. Table 4 indicated potential findings for publications from known and reliable sources.

After combining the scores to the above questions, a final score (between 0 and 8 ) was determined for each study. Only papers included with four or more ratings in the final results.

\section{iv. SELECTION BASED ON SNOWBALLING}

Following the standard assessment, backward snowballing was performed, employing a reference list from any completed analysis to retrieve papers [77] and chose only those significant articles that met inclusion/exclusion requirements. After reading the introduction and then other portions of the document, the article's inclusion/exclusion was determined.

\section{REVIEW REPORT}

This section provided an overview of the selected studies.

\section{i. OVERVIEW OF INTERMEDIATE SELECTION PROCESS OUTCOME}

MALL was a very active topic, and our analysis approach had to extract relevant research empirically and systematically from the Web of Science core collection. The next step of our systematic analysis was compiling records that form the foundation for this analysis. Approximately 57,000 papers were examined from the archive by providing the keywords for 2010- 2020. After creating a knowledge base from the digital library (Web of Science), the author reviewed the title, abstract, and accompanying complete document for each search result, as needed. During this process, irrelevant papers or papers of less than four pages were 
265 eliminated. During the inspection process, selected documents in the fields of MALL, mobile

266 learning, and m-learning were read extensively to assess their significance \& contribution and

267 then created a comprehensive knowledge foundation of papers based on their findings to

268 accomplish this research's core objective.

269

270

271

272

273

274

275

276 IV. ASSESSMENT AND DISCUSSION OF RESEARCH QUESTIONS

277

278

279

280

281

282

283

ii. OVERVIEW OF SELECTED STUDIES

Table 5 presented significant results of the primary search, filtering, and reviewed processes that included Web of Science indices. At the filtering/inspection stage, this amount decreased to 63 articles by the automatic search.

In this section, finalized 67 primary research studies based on our research questions were scrutinized.

\section{RQ1: What are the high-quality publication channels for MALL research, and which geographical areas have been targeting MALL research over the years?}

284 The analysis of MALL with the integration of game elements in learning tools, methods, content,

285

286

287

288

289

290

291

292

293

294

295

296

297

298

299

300

301

302

303

304

305

306

307 and the theoretical perspective choice was a crucial challenge for scholars to use in education. Identifying fine publication sites and scientometric analysis based on meta-information in MALL domain was required for the purpose. This section consisted of perceptive knowledge of research publication sources, types, years, grade level distribution, geographical distribution, publication channel-wise distribution of selected studies to analyze MALL research.

The studies finalized from the Web of Science (core collection) were presented yearly, as shown in Table 6 and Figure 5. Twelve was the maximum number of publications selected from the year 2019, out of the total 67, indicated more interest in developing MALL with integrating games in teaching and learning. However, less interest in MALL with game research integration was observed in 2010-2016 and 2018-2020, resulting in less improvement in teaching and learning in relevance to students and market needs.

Table 7 and Figure 6 present the geographically distributed studies. The majority of publications, or 39 out of 67, were from different Asian countries, whereas European countries published 15 reviews. North American countries published eight studies, while Africa and Ocean-continent have three and two studies published, respectively.

The data presented in Table 8 showing that the maximum number of articles were from highly recognized journals indexed in the Web of Science. Only one item was from a good ranked conference. Computer \& Education journal was on the top of the list from which seven papers were selected and next, the Educational Technology \& Society journal with four articles. According to conditions defined in section III B.3, each finalized study's QA score was granted, as shown in Table 4, offering the QA score ranging from 4-8, with less than four discarded scores. MALL researcher might find this QA supportive to choose related studies while addressing its usage and challenges. Articles published in Q1 journals mostly scored maximum while scoring four from less recognized journals but relevant to the subject matter. A total of 26

309 out of 67 scored maximum (i.e., eight (8), indicating fulfillment of all QA criteria, whereas nine

310 (9) studies scored four out of 67, which is the lowest in QA. 
311 Table 9 presented the overall classification output and QA of finalized studies, and Table 10

312 showed the overall quality assessment score. Studies were classified based on five factors: the

313 empirical type/method, research type, and method. Categories of research types were; Evaluation

314 framework, Evaluation research, Solution proposal, and Review. The taxonomy presented in

315 section $V$ was constructed on these defined research types. Studies that analytically validated

316 their results from the statistical analysis, experimentations, surveys, or case studies to increase

317 their quality standards awarded a score. In category (c) of quality assessment criteria, only 8 out

318 of 67 reviews did not present empirical results, thus awarded zero scores. Only five studies

319 scored zero for category (d) of quality assessment criteria; the rest of them scored higher,

320 indicating competent sources. Four (4) recorded the lowest score awarded for a study.

321

322

323

\section{RQ2. What are the widely used theories, models, and frameworks proposed or adopted for MALL research?}

324 This section provided the framework/conceptual model based on the situation (proposed/adopted by the researcher) after an essential discussion of the theories, frameworks, and models.

\section{A. THEORIES:}

Theory of planned behavior: The Theory of planned behavior (TPB) noted that behavioral

328

329 intentions motivated human behavior. Behavioral intentions rely on three determinants; an individual's mood, cultural norms, and perceived influence [1].

330 Sociocultural theory: Sociocultural theory recognized human evolution as socially influenced by

331

332 cooperation with more professional members of society, through which children learned their cultural norms, ideologies, and problem-solving techniques [2] [107]. Experiential Learning Theory: The concept of experiential learning was implemented in a learning game. Players performed exercises to seek information within a gameplay environment that made the learning process enjoyable, engaging, and interesting [28].

336 Dual-Coding theory: The dual-coding theory suggested that the verbal and imagery systems

337 (mental images and representations) could be co-activated as rich and substantive referential

338 relations connected dual-coded objects [31]. Theory of cognitive style: Two types of learning, field independence and field dependence, were based on critical and interpersonal personality characteristics. Field-independent students were independent-minded, and the social environment could not readily affect their learning style. Field-dependent students tended to learn in visual settings or scenarios [40]. Attribution theory: Bouchaib [44] used Weiner attribution theory (1992) as a framework that provided failure or success reasons or explanations for people in education. Moreover, it was also a social cognitive theory of motivation.

346 Instructional theory: The instructional theory sought to explain how people can learn, evolve, and established environments that promote learning opportunities and strengthen teaching [52] [108].

\section{B. FRAMEWORKS \& MODELS:}

'Here and now' mobile learning framework: Three characteristics (Engaging, Authentic, and Informal) Framework identified the effect of mobile learning on the learning environment [3]. Mobile English learning outcome (MELO) framework: This research developed the Mobile

354 English Learning Objective (MELO) to examine the correlation between learners' understanding 
355 of mobile technologies using playfulness, resistance to change, and self-management constructs

356 of the Framework [13].

$357 M-C O P E$ : It is a study that came up with the M-COPE framework to support teachers in building

358 mobile learning experiences using the ADDIE model, which allowed teachers to understand five

359 main aspects of mobile learning: Mobile affordance, Ethics, Pedagogy, and Outcomes [17].

360 Mobile English learning continuance intention (MELCI): The study came up with TAM

361 components (Davis, 1989) adopted in mobile English learning. Continuance intention framework

362 to examine the influence of mobile learning satisfaction with self-management of learning [21].

363 Pedagogical Framework: Task-based language teaching (TBLT) was a pedagogical framework

364 concerning language instruction strategy that focused on curricular design units and an

365 instructional cycle aspect. It focused on the interaction method, which implied that the

366 negotiation of importance led to a detailed and internationally changed input [43].

367 The affordance framework: The affordance framework, which comprised pedagogical, social,

368 and technological components, examined the ICT tools affordance for language learning [59].

369 Technology Acceptance Model (TAM): The TAM demonstrated many knowledge predictors by many researchers, focusing on the rational action theory. TAM has five components: perceived

372 ease of usage, perceived effectiveness, the intention of behavior, intention to use, and discrete use. The model played an essential role in forecasting the use of various factors [24].

Extended Technology Acceptance Model: The study examined mobile applications' impact on students' usage intention, perceived ease of use (PEOU), and usefulness. The research outcome was an extended technology acceptance model [19].

376 ARCS Model: A motivational model ARCS (Attention, Relevance, Confidence, and Satisfaction)

377 that motivated learners and procedural assistance in compliance to demand used in this research. This model has three features: 1) emphasized motivation and emotional stimulation, 2) integrated with other theories and design, 3) enhanced the instruction effects and learning process [20].

380

381

382

383

384

385 A Theoretical Model: Discussion of two frameworks: 1) Framework for the rational analysis of mobile education (FRAME). 2) TAM and TAM 2, the author proposed a new theoretical model that focused on the technology enhancement, non-formal learning setting, and learner-centered to develop a better understanding for EFL learners using mobile English learning resources (MELR) for Chinese postgraduate students [57].

386

In this section, the Theory, Framework, and Model used in the studies were described and summarized in Table 11.

A conceptual model based on the Theory of Planned Behavior (TPB) explained how young adults' acceptance and attitude affect their intention to embrace mobile devices in their classroom practice [1]. The Framework in [2] criticized pedagogy, allowed a comparison of mobile approaches and pedagogical methods, and their importance to the sociocultural nature of learning in mobile learning environments validated by m-learning researchers' discussion among designers of the Framework, implementation in a project, and pedagogical experts. Similarly, three characteristics (Engaging, Authentic, and Informal) Framework were created to see mobile learning's effect on the learning environment by measuring students' achievement and attitude [3]. A hypothesized m-learning model was proposed based on the Technology Acceptance Model (TAM) components - Perceived Usefulness (Near-term/Long-term usefulness), Perceived Ease of use, Personal Innovativeness, and Behavioral Intention. This model was assessed based on data collection from 230 participants using a survey questionnaire [4]. A paradigm for the Mobile English Learning Objective (MELO), in which learners' understanding of mobile 
400 technologies may be directly correlated with three objects: Playfulness, Resistance to change,

401 and Self-management that were adapted after discussing extensive literature [13].

402 The M-COPE framework supported teachers to build mobile learning experiences using the

403 ADDIE model. This Framework allowed teachers to understand five main aspects of mobile

404 learning: Mobile affordance, Ethics, Pedagogy, and Outcomes. It was validated by five experts

405 [17]. The computational model concept and their proposed connections resulting from Davis

406 (1989) TAM were introduced in which perceived ease of use, perceived usefulness, and

407 perceived contextual variables were measured. This model was validated through SmartPLS 2.0

408 [19]. A motivational model, ARCS (Attention, Relevance, Confidence, and Satisfaction) that

409 considered learners' motivation and procedural assistance in compliance to demand, was used to

410 measure effectiveness and learning motivation. This model has three features: 1) emphasize

411 motivation and emotion stimulation, 2) integrated with other theories and design, and 3)

412 enhances the instruction effects and learning process [20]. A mobile English learning

413 continuance intention framework was used. TAM (Davis, 1989) was adopted to see the influence

414 of mobile learning English satisfaction with self-management of learning to measure Perceived

415 Usefulness, Perceived Playfulness, and Resistance to change. The internal consistency and

416 reliability were measured through the PLS-SEM application [21].

417 The study adopted the TAM by incorporating perceived convenience and curiosity factor for

418 mobile learning. To examine the validity of the measurement model, Confirmatory Factor

419 Analysis (CFA) was performed with SmartPLS [24]. In contrast, experiential learning theory was

420 used because players seek knowledge by doing activities in the game environment. Moreover,

421 the learning process was exciting, challenging, and relevant, along with substantial experience

422 provided to the players where learner motivation and effectiveness were measured [28]. In a

423 dual-coding theory, the working memory model and multimedia principle used for pedagogy in

424 this study were validated by doing an extensive literature review [31]. In this research, self-

425 directed learning, Garrison's comprehensive theoretical approach of (1997), was used to measure

426 self-directed learning (motivation, self-management, and self-monitoring) [32] whereas 'English

427 Fun Dubbing' application was designed for practicing English orally, and evaluation of the

428 application's effectiveness (convenience, flexibility, user-friendliness, rich material, language

429 context) was carried out by [35]. An application was developed to observe the multimedia

430 glosses' effect on second language listening comprehension and vocabulary learning in a mobile

431 learning environment. Its effectiveness was measured by the author [38].

432 Business language testing service (BULATS) adopted a framework based on Teaching Method,

433 Learning Satisfaction, Learning Effectiveness, and qualitative analysis to measure satisfaction

434 and attitude [39]. 'MyEVA Mobile' is a mobile-based application developed to explore the

435 learning attitude, learning achievements, learning styles, and university students' strategies to

436 improve the students' vocabulary that worked any time and without the internet. The framework

437 components are 'Smartphone client,' 'Wireless device,' and 'Log Analyzer Server.' Learning

438 behavior, Perpetual learning styles, and Knowledge proficiency were measured in this study

439 [40]. In another study [43], task-based language teaching (TBLT) was used as a pedagogical

440 framework to measure technology-mediated TBLT. 'Weiner attribution theory (1992) was used

441 as a framework that provided failure or success reasons or explanations for people in education

442 [44]. Moreover, WhatsApp and Google were used to enhance the reading ability to measure

Peer] Comput. Sci. reviewing PDF | (CS-2021:02:57961:1:1:NEW 17 Mar 2021) 
443 learner autonomy [45] and retain business vocabulary, whereby an application

444 'Excel@EnglishPolyU' was developed and tested with undergraduate students [46]. To design

445 and implement a mobile-based English vocabulary application for distance learning students in

446 South Africa, 'VocUp' was developed, and its evaluation measures usability, scalability,

447 reliability, and flexibility [50].

448 A theoretical framework for 'Word Score' serious game was developed based on Bom (2011) by

449 exploring the literature to measure this study's motivation [52]. In contrast, an architectural

450 model was proposed in the study. The Pedagogical model, and learner model, were used by pilot

451 testing [54], whereas a mobile game for tenses' SOS Table' was developed. The evaluation

452 measured its effectiveness, user's motivation, acceptance, and attitude within the Framework of

453

454

455

456

457

458 mobile learning tools [56]. Moreover, by discussing two frameworks: 1) Framework for a rational analysis of mobile education (FRAME) and 2) TAM and TAM 2, the author proposed a new theoretical model that focuses on the technology enhancement, non-formal learning setting, and learner-centered to develop a better understanding for EFL learners on mobile English learning resources (MELR) in English language learning for Chinese postgraduate students [57]. Furthermore, it was also a social cognitive theory of motivation. Simultaneously, the affordance

459 framework consisted of pedagogical, social, and technological components, used to examine the ICT tools affordance for language learning [59]. TAM was used in the study to measure perceived usefulness and ease of use [61].

462

463 Summarize the table 11, researchers developed applications and games for language learning in which majority of these developed for English Language Learning and vocabulary. Similarly, less application and games were developed for pedagogy [2] [17] reading [6] [12], pronunciation [16] idioms [18] [26] tenses [56] grammar [58-59] spellings [113] achievement, attitude, usefulness, usability and effectiveness [3] [4] [60-63]. From the selected studies, various models/frameworks were used as a base for developing an application in which TAM [6] [12] [24] [61-62] mostly used. Many applications did not use any model or Framework as the base for the purpose.

\section{RQ3. What are different application domains for the MALL application, and in which various forms are these applications exposed for the end-users?}

473

474

475

476

Several tools have been designed and developed by the researchers in MALL to support the students and teachers in learning the English language. A more in-depth analysis presenting that most of these tools and applications are student-centric and focus on learning [61]. While some of them support teachers in teaching and students in learning, thus can be categorized as a teaching and learning tool [61]. On the other hand, very few tools focus only on teaching [59]. Lastly, another emerging trend has been observed where these tools are augmented with gamification to make them more exciting and useful for the stakeholders [58]. Table 12 presents these tools in different categories above.

481

482

483

484

485

486

487

\section{A. Learning Aspect:}

A mobile adaptive language learning system in which recommended material for reading and reading annotation facilities was provided to pupils to improve learning outcomes [6]. A Mobile learning tool and five-step vocabulary learning (FSVL) strategy were developed in a situational learning environment to assess their effects on English as a foreign language (EFL) performance and learning motivation. According to the mobile learning tool, a global positioning system 
488 (GPS) was used to develop and provide learning material [11]. Similarly, a mobile learning 489 application 'Raz-Kids' for an extensive reading program was designed by 'Learning A to Z'. The 490 tool aimed to create the concentration of the students to enhance their essential reading ability.

491 Furthermore, it provides e-books of alphabets for students and teachers' class management tools

492 [12].

493 The study conducted experimental research using ASR, Non-ASR, and Control Group. The ASR 494 group Nuance Dragon Dictation application was designed and installed on their mobile phone to finish weekly pronunciation activities with immediately written visuals (Pictures) feedback provided by the application without any human interaction. Five native French speakers pronounced all words and phrases to test the application [16]. In a study by [24], 'Mebook,' a multimedia eBook system that can be played in the format of MP3 was developed. It integrated text, images, voice, and pictures that provided directions for listening, speaking, writing, and reading.

Furthermore, it also included speed adjustment of audio and switching of language from English to Chinese and Chinese to English. Duolingo, a free mobile assisted language learning tool (for vocabulary acquisition) is available in the web and mobile (Android and iOS) versions to examine out of class engagement informally. Translation exercises of sentences and words are the delivery method of this application. Moreover, instructors can see logs and progress to keep an eye on the students [34]. A mobile-based gaming approach for English grammar and vocabulary learning 'Save the princess with Teddy' was developed and students' learning achievement with gameplay at different levels was analyzed. It was hoped to enhance students' learning motivation with the game and assistance to learn the English grammar concept [58]. In the context of academic English, a mobile data-driven learning (DDL) experiment was discussed by designing and developing an application' AKWIC (academic key words in context)' for voluntary. This application provided support for academic writing (vocabulary learning), and

513 data were obtained from logs generated by the application [41].

514 An SMS text message application, 'Fetion' explores the effectiveness of vocabulary learning using mobile technology. Specifically, SMS from mobile phones enhanced English vocabulary than outdated printed material [9]. In contrast, a location-based vocabulary learning activities application for Thai and German users was proposed in a study with personalized learning motivation. Moreover, the aim was to enhance user acceptance by providing relevant learning content to evaluate an online questionnaire [19]. A free mobile assisted language learning tool (vocabulary acquisition) 'Duolingo,' available for web and mobile (Android and iOS) versions examined out of class engagement informally. Translation exercises of sentences and words are the content of this application, and instructors can see logs and progress to track students' progress [32]. 'Mobile assisted listening application' was developed to examine L2 multimedia glosses' effects in a mobile learning environment, for vocabulary and listening comprehension, validated through a pilot study [38].

526 An offline mobile assisted language learning application system, 'My English Vocabulary

527 Assistant mobile edition' (MYEVA Mobile) was developed to engage students in mixed-

528 modality vocabulary learning to improve their vocabulary. The users learned targeted words via four vocabulary learning strategies: flashcard, imagery, word card, and Chinese assonance. A log analyzer server was installed, and $\log$ files were used to analyze the results [40]. Furthermore, a mobile application like WhatsApp and Internet search engine (Google) were used by students to access materials for reading and interaction with peers and instructors outside the class. This application was used to improve learning skills in EFL reading [45]. 
534 A crowdsourced mobile-based 'LingoBee,' an open-source and freely available application,

535 explored creativity and mobility in language learning. It was the part of the European countries'

536 project "SIMOLA," designed to help collaborative language learning using the idea from social

537 networks and crowdsourcing. Users created content for language learning, stored it on their

538 device, and shared it with other users via a cloud-based repository. The application was

539 evaluated through user studies in European countries [27]. In contrast, an application 'English

540 Practice' was used to analyze the usage behavior of 53,825 users from 12 countries, and the

541 evaluation was conducted through log files generated by the Google Firebase analytics tool [37].

542

543

544

545

546

547

548

549

550

551

552

553

554

555

556

557

558

559

560

561

562

563

564

565

566

567

568

569

570

571

572

573

574

575

576

577

578

579

580

\section{B. Teaching and Learning:}

An online assessment tool, 'Grammar Grabber,' was discussed in this study to evaluate grammar at the school level. Using this tool, users do practice online and get constant feedback to know their performance. The authors investigated this online assessment tool to perceive pedagogical, technological, and social affordances using multiple-choice questions and allowing re-attempt for wrongly answered questions. The log files of the application were used as the dataset [59]. An application, 'Literacy and Numeracy Drive' to teach and learn languages, was discussed at the school level. This application provided some practice and then some assessment exercises for the English language. This application aimed to teach singular/plural, use of has/have/had/is/am/are/ was/were, and reading comprehension [61]. A serious online game that was designed to extend the students' vocabulary in primary school was discussed in this study. This game was part of the national project 'Educational Time Extension (ETE).' The students spend more time than expected class timing to learn and improve their vocabulary. Applications for teaching and learning at the college level was not adopted/developed for English language learning in the selected studies.

LINE App, an application that was used to investigate the teaching of English for specific purpose (ESP) effects on Business Language Testing Service (BULATS) [39]. Whereas 'Mobagogy' a professional learning community of academicians to investigate the use of mobile technologies in learning and teaching while 'The bird in the Hand' initiative by the UK to examine the experience of trainee and newly qualified teachers by providing them smartphones to use in their offices and teaching schools to enhance professional practices of pedagogy. Australian University developed the application Mobagogy', and The Bird in the Hand was sponsored by the UK [2] to evaluate the benefits of mobile applications and an application 'English Fun Dubbing' designed for English's oral practice its users. Learning material in this application was: animations, songs, movies, short videos, and textbooks developed by the Chinese Sci-Tech Company [35]. To enhance teaching and learning of English vocabulary, a mobile-based application 'VocUp' was designed and implemented to evaluate external parties [50]. A mobile application, 'WhatsApp' was used in this study to examine the efficiency of teaching 40 phrases.

Furthermore, the study also aimed to enhance vocabulary acquisition [51]. An application 'Anglictina (English) TODAY' was developed by a Ph.D. student of Computer Science with a language teacher's help. This application helped pupils for the preparation of final exams by learning from anywhere at any time. To discuss students' perception of using a mobile application, this was developed based on their needs to make EFL vocabulary teaching and learning useful [55].

\section{Gamification based learning and teaching:}


581

582

583

584

585

586

587

588

589

590

591

592

593

594

595

596

597

598

599

600

601

602

603

604

605

606

607

608

609

610

611

612

613

614

\section{5}

616

617

618

619

620

621

622

623

624

625

626
A serious game 'MEL application' developed in which 25 animals from five continents (Asia, South-America, Africa, Oceania, and North-America) were involved developed. The game was played during the visit to the zoo and at home in which two modes were available in which one was totally related to the zoo situation. One was independent of GPS that allowed children to access animals in different continents [5]. To investigate a mobile English learning application that would be supplement and support for learning English at school was adopted for the study by enhancing game features. The application's learning material on animals from the zoo resulted in the students' outperformance using the mobile application for a fortnight than users for a fixed period [10]. A game-based system, 'Happy English Learning System', in which learning material was integrated to experiment, was installed on mobile devices to see the learner's motivation for achievement. The activities were divided into levels of difficulties: Easy, Medium, and Advanced, according to the ability of users [28].

Game-based applications Excel@,EnglishPolyU, Alphabet vs. Aliens, and Books vs. Brains@PolyU, business vocabulary after completing level challenges may acquire by the learners [46]. Similarly, an application, ' PHONE Words,' was developed by Alice English Education Studio for vocabulary learning, designed with game functions (MEVLA-GF) and without game functions (MEVLA-NGF) to investigate the perceptions and measure the learning performance of learners. This application also provides an assessment with a gamified competition mechanism [47]. To give the students' opportunity, 'SOS Table,' a mobile-based game application, was designed and developed to repeat tenses, high-frequency words, and sentence string. Time challenge was provided to create negative, positive, or correct sentences with words and pronunciation after completing the task [56]. The serious game was not adopted/developed at the college level for English language learning in the selected studies. In the study [8], an augmented reality-based language learning game developed for Spanish in Southwestern US to explore foreign and second language learning's benefits and complexities. Similarly, a mobile-based English Vocabulary system for practice was designed and developed not to replace traditional classroom teaching methods. The aim was to provide students with assistance to review, proficiency, and practice in and after the class. The game system was designed based on the ARCS model, which provided assistance in vocabulary learning and listening and worked as a testing tool [20]. 'Idiomobile' a mobile-based game that was made available for specific handsets based on the knowledge of using idiomatic expressions in a critical situation [26].

\section{RQ 4. What is the specific content adopted for teaching and learning in MALL research?}

Teaching and learning through MALL by applying pedagogical skills or tools after adopting appropriate content are summarized and discussed in this section. The current section is divided into four sub-levels, i.e., Learning, Teaching and Learning, and Serious Game based presented in Table 13.

The content usage for learning aspect in MALL about reading perspective discussed for the undergraduate students of public university enrolled in "Computing and Information Technology (CIT) adopted as curriculum [1]. Whilst personalized recommended learning material with reading annotation services were categorized into three difficulty levels: elementary, intermediated, and intermediated high level [6]. In the study [19], discussed that multimedia learning material in the written and audio-visual form provided using the app according to the

PeerJ Comput. Sci. reviewing PDF | (CS-2021:02:57961:1:1:NEW 17 Mar 2021) 
627 user's relevant current position. Words and pictures were adequate for learners to learn

628 vocabulary by solving word pair quizzes. The content adopted in [24] was broad and varied,

629

630

631

632

633

634

635

636

637

638

639 including current issues related to education, economy, environment, social, politics, technology, etc. For English learning, the topic areas covered were speaking, listening, reading, and vocabulary. To teach most popular idioms, content relevant to idioms and collocations was collected for application from books and websites [26].

A cooperative creation of multimedia content by adding it to new vocabulary is then stored on the devices and uploaded on the cloud by the users that can view or brows LingoBee repository by sorting it chronologically or alphabetically [27]. The study [28] discussed the curriculum for English subject consisted of the topics: phonetic symbols, alphabet, grammar, phrases, vocabulary, and sentence patterns used by pupils to review it and also can share with the class by using social media (i.e., Facebook) whereas the course content in application 'Duolingo' focused variety of subject-specific vocabulary acquisition by learning nearly 2000 words. The

640

641

642

643

644

645

646

647 application's delivery techniques were translating from source to users' target language, choosing right translated phrases, paring of words from languages, flashcard practicing, and translation of unknown words [32].

Teaching is a method of discussing and interfering with people's desires, perspectives, and emotions to learn specific things [89]. The reading perspective in teaching is discussed by [40] in which the content used for vocabulary teaching, suitable for 'Test of English for International Communication (TOEIC) that is a standardized test used in Taiwan. Fifty words were taken for vocabulary was chosen from TOEIC, including different difficulty levels.

649

650

651 Current studies investigated the content usage according to speaking, listening, reading, and writing in teaching and learning through MALL. An application designed by the Chinese SciTech company to assist in English practice orally provided rich learning material of animation movies, short videos, songs, and textbooks with English speakers speaking for different age group students [35]. From the reading perspective, 'Word Capsules (short vocabulary test)' was developed in which words (content) were selected from 10,000 words, who gripped numerous

654 phrases in English have a vast vocabulary and able to survive with challenges of studying at a higher level in English [50]. In contrast, for all the viewpoints, practicing and retaining new phrases and words, ten lessons of vocabulary and ten lessons of phrases were adopted as content that the pupils have to translate to English from native language [55].

658

659 The content used in game-based applications for reading perspective investigated from selected studies in which the content was pictures and videos to learn about the zoo animals [5]. Learning

660 Spanish Augmented reality game-based language learning tool was also investigated in which

661

662 classroom curriculum was adopted for the game for three to four-week timeframe [8]. For vocabulary practice through a game-based system, a presentation model combined learning content with difficulty levels (easy, medium, and advance) [20]. Still, for vocabulary learning using MEVLA-GF, the perception of interviewees identified gamified design, interface design,

665

666

667 and content design that satisfy the learners' need for different purposes and at level [47]. In the study of [58], learning material consisted of vocabulary, sentence examples, grammar examples,

668 and grammar concept mapping for English games in elementary school. The purpose was to make a strong foundation of English grammar and enhance its knowledge with the

670 what were the evaluation measures and tools used for their evaluation? 
673 RQ5 was posed to investigate the evaluation methodologies and tools used by the MALL studies 674 are presented in Table 14 and Table 15 . Table 14 shows that 33 out of 67 studies adopted or

675 developed a questionnaire to collect data from the selected population. In contrast, only six

676 studies used interviews and observations for their studies. The mixed-method approach in which

677 questionnaires, interviews, and observations were used as a tool for collecting data by 18 studies

678 while only five studies used discussion and other methods for their data collection.

679 EVALUATION:

680 The evaluation in this section was teaching and learning and technical perspective. Researchers 681 used various methods to collect data, and statistical tests were applied to analyze the data to 682 produce relevant results. The statistical tests for analysis applied through various tools were, i.e., 683 SPSS, PLS, etc. The methodology and tools used by the selected studies were presented in the 684 following section.

\section{a. MEASURES FOR TEACHING AND LEARNING}

686

687

688

689

690

691

692

693

694

695

696

697

698

699

700

701

702

703

704

705

706

707

708

709

710

711

712

713

In the teaching and learning section, terminologies were described from the selected studies also presented the instruments used in these studies were shown in Table 15.

Pedagogy: a study of educational techniques, including the purposes of instruction and the approaches to accomplish them [92].

Motivation: originates from the term 'motive' that means needs, wants, wishes, or drives in people. It is the method of inspiring individuals to take steps to meet the targets [93].

Perception: To organize, define, and interpret sensory input to reflect and recognize the input or situation presented [102].

Curiosity: originated from the flow concept, which means people prefer to communicate in the state of flow with their surroundings. Curiosity is preserved when people consider the world as fun or fascinating [24].

Continuance Intention: The level to which people intend to keep using smartphone English learning [24].

Attitude: An optimistic, pessimistic, or mixed assessment of an entity communicated at a certain level of anxiety. This represents an advantageous or disadvantageous assessment of a person, position, object, or event [94].

Achievement: Somebody succeeded in achieving something, particularly after much effort [103]. Self-Directed Learning: A learning approach that encourages learners to take control of their learning method (diagnosis requirements for learning, assessment of learning priorities, choice of learning methods, and the measurement of academic achievement and outcomes) [95].

Behavior Pattern: A repeated way for a person or group to behave against a particular object or condition [96].

Learning Behavior: Learning Behavior stresses the crucial relationship between child and youth learning and their social experience and behavior [97].

Learner Autonomy: The autonomy of learning is when pupils take care of their learning, both in respect of what they learn and, in the direction, they study it [104].

Affordance: An affordance is an object quality or a condition that makes it possible for the person to take action [101]. 


\section{b. TECHNICAL EVALUATION MEASURES}

715 It is the Human-Computer Interaction (HCI) category to measure the applications' UI/UX [62].

716 The following were the terminologies discussed in selected studies also, approaches used in these 717 studies were shown in Table 14 and Table 15.

718 Usefulness: The perceived usefulness (PU) is also one of the separate structures in the TAM. It is

719 the extent to which a person believes that a specific process may improve the efficiency of his /

720 her job [91] [105].

721 Ease of Use: The primary use of computer programs in the TAM is a significant determinant of

722 the target. A discreet individual describes a simple usage as evident in implementing a procedure

723 and directly impacts the perceived usefulness [61].

724 Effectiveness: Effectiveness is a participant's ability to execute a task in a given context. In

725 general, efficacy is assessed by determining whether participants can carry out such tasks [90].

726 Perceived convenience: The extent to which users perceive mobile English learning to be

727 comfortable in terms of time, location, and the method to complete a task [24].

728 Usability: Usability is a common factor that determines how convenient it is to use interface

729 design. The term "usability" also applies to the approaches used during the design process to

730 increase ease of use [91].

731 Efficiency: Efficiency is the user's ability to deliver their role quickly and productively,

732 representing the user's value during its use. Quality can be calculated in various ways, for

733 example, the time taken to complete or the number of keystrokes necessary to finish a task [103].

734 Scalability: Scalability is characteristic of an entity, structure, model, or process, defining its

735 ability, under increased or expanding workload or scope to handle and compete well [98].

736 Reliability: Reliability means the possibility that a product, device, or service can perform its

737 intended function properly for a given period or work without interruption within a fixed

738 environment [99].

739 Flexibility: Flexibility is a characteristic that explains how a person can tolerate changes in

740 situations and think in novel, imaginative ways about issues and tasks [100].

\section{c. EVALUATION METHODOLOGIES}

742

743

744

745

746

747

748

749

750

751

752
The methodology is the basic techniques or methods used to identify, collect, retrieve, and interpret information on the topic [79]. A quantitative study using a quasi-experiment (Pre-test and Post-test) was conducted by [6] [20] [24] [49] [52] to collect data through questionnaires whereas, a quantitative study using questionnaire only was conducted by [35] [46] [54]. A mixed-method approach was used [26] [32] [40-41] [56-57] [61] to conduct interviews and questionnaire for the collection of information, whereas a qualitative approach in which interviews were conducted by [45] [50].

\section{i. STATISTICAL ANALYSIS:}

Statistical analysis is data compilation and evaluation, allowing patterns and developments to be discovered [80]. The following were the statistical analysis techniques used by the selected studies:

Peer] Comput. Sci. reviewing PDF | (CS-2021:02:57961:1:1:NEW 17 Mar 2021) 
753

754

755

756

757

758

759

760

761

762

763

764

765

766

767

768

769

770

771

772

773

774

775

776

777

778

779

780

781

782

783

784

785

786

787

788

789

790

791

792

793

Mean and Standard Deviation: Mean which is the average of data set (adding all the numbers then divided by its total point) [81] was calculated by [4] [12] [26-27] [38] [40-41] [52] whereas Standard Deviation (SD) measures a dataset's dispersion relative to its mean and is calculated as the square root of the variance [82]. It was calculated by [20] [32] [52] [61].

Analysis of Variance: Analysis of variance (ANOVA) is a statistical method that evaluates a nominal level variable with two or more categories in a scale level dependent variable [83] was calculated by [4] [6] [12] [38] [49].

T-test: The independent t-test is a method that contrasts two sets of a variable usually distributed on a mean value of a constant (e.g., interval or ratio) [84] was calculated by [20] [27] [56]. Analysis of covariance: Analysis of Covariance (ANCOVA) is the inclusion of a continuous variable in addition to the variables of interest (i.e., the dependent and independent variable) as means for control [85] calculated in [6] [40]. Multivariate Analysis of Variance: Multivariate Analysis of Variance (MANOVA) is similar to ANOVA, except that instead of one metric dependent variable, having two or more dependent variables and is concerned with examining the differences between groups [86] calculated by [12] [38].

Linear Regression: Linear regression is an analysis that assesses whether one or more predictor variables explain the dependent (criterion) variable [87] calculated by [27].

Frequencies: A frequency distribution is a graphical or tabular representation that indicates the number of observations over a given interval [88] calculated by [35] [46] [54] [57].

It is showing by Table 14 and Table 15 that questionnaire tool was used to evaluate motivation [5], perception [6], effectiveness [11], usefulness [12], convenience [20], curiosity [24], achievement [27], attitude [28] [34], behavior [40], and perception [55], whereas interviews were conducted to measure the learners' autonomy [45], usability, scalability, reliability, and flexibility [50]. Few studies used questionnaire and interview (both) to see the attitude and motivation [26], effectiveness [41] [56], perception [47], affordance [59], usefulness, and ease of use [61]. In contrast, only [39] study used a questionnaire with class observation to measure students' satisfaction and attitude.

\section{ii. Tools used for analysis:}

Table 16 presented that 39 of the papers used statistical package for social sciences (SPSS) software which was of quantitative in nature, used to evaluate their research. Partial Least Squares (PLS) was also used by two (02) studies [21] [24].

Nvivo is a tool that was qualitatively used by [30] [41]. After conducting interviews of their respondents, while only two (02) studies [55] [59] evaluated their results manually to present in the articles. Mplus is a statistical modeling program that allows researchers to analyze the data used by [1], whereas 'Wenjuan Wang' an online tool to analyze data used in China by [35].

'Facets, ' 'Google Firebase,' 'Notes taking,' online tool, and 'Google Sheet' used by [36-37] [45-46] and [53], respectively. In this literature review, eleven (11) studies did not use any online or desktop application to analyze the data.

Peer) Comput. Sci. reviewing PDF | (CS-2021:02:57961:1:1:NEW 17 Mar 2021) 
794

795

796

797

798

799

800

801

802

803

804

805

806

807

808

809

810

811

812

813

814

815

816

817

818 Gamified applications are proposed for vocabulary learning [5] [10] [20] [47] [52], Spanish

819

820

821

822

823

824

825

826

827

828

829

\section{DISCUSSION AND FUTURE DIRECTIONS:}

831 This section summarizes and discusses the results related to the systematic literature review.

\section{RQ6: Compare the usage of simple mobile applications with gamified applications (Serious Game) for language learning?}

Figure 7 shows the trend of language learning applications and games developed during selected studies of 2010 to 2020 . It can be observed that in the years 2010 and 2011, few applications related to mobile-based and gamified language learning applications have been proposed as fewer people were familiar with this area. From the year 2013 to 2014, an increasing number of gamified application gamified applications were proposed for the studies. Similarly, there are increments from 2017 to onwards for mobile-based gamified applications to learn how educational institutes were observed in the finalized studies.

Mobile and gamified language learning applications from the selected studies concerning level, purpose, evaluation method, and results are presented in Table 17. The applications are divided into two categories: 1) Mobile application, 2) Gamified applications (serious games). Mobile applications are proposed for teaching [2] [35], reading [6] [12] [45], vocabulary learning [9] [11] [19] [27] [32] [38] [40-41] [50] [55], pronunciation [16], writing, reading, listening and speaking [24], listening comprehension [38], grammar [58] and reading comprehension [61]. The results presented by studies for the applications of pedagogy, reading, pronunciation, writing, listening, speaking, grammar outperformed the control group. It may be concluded that mobile applications for vocabulary learning have a positive impact on language learning in which pupils from the experimental group outperformed the control group except [55] [61] where the students and teachers mentioned they are not satisfied with the design, content, assessment methods adopted in the applications besides pronunciation support and teachers' notifications were also missing. language learning [8], Idioms [26], Vocabulary, Grammar, and Sentence Structure [28], and Tenses, Words, Sentences [56]. The results presented by studies for gamified applications of vocabulary learning, Idioms, grammar, sentence structure, tenses, and words outperformed the control groups with much engagement, interest, and positive feedback. Although mobile applications are effective, gamified applications are more effective with enhanced interest and engagement, resulting in positive learning outcomes [60-63]. Furthermore, it may be concluded that gamified applications are trending for all the subjects at all levels of education to get significant learning performance [63] [105-106] [115-116]. Furthermore, [61] recommended gamified application in the public sector school to effectively learn the English language (specifically reading comprehension at primary level) after addressing all the stakeholders' issues.

832 A. TAXONOMIC HIERARCHY 
833 In this comprehensive literature review, the aim was to investigate current MALL information 834 and its application with 63 selected papers. To achieve this objective, a taxonomic hierarchy of

835 finalized studies shown in Figure 8 was established and examined trends and perspectives on

836 adapted/developed frameworks, content, and teaching and learning tools. However, these

837 dimensions were further broken down into several sub-levels that illustrated each area's scope

838 with its role in enhancing the efficiency of language learners.

839

840

841

B. FUTURE DIRECTIONS

842

It was suggested that MALL specific theories or models might be developed because the models

843

844 used from fields other than MALL was to be adopted or adapted as all components of the models used in the studies could not be applied to measure the constructs. The researchers used varying

845 theories or models to develop a theoretical framework of the respective studies, and this practice was too time-consuming, and the models were minimum valid. The researcher confronted the

846 same issue while measuring usability, usefulness, effectiveness, ease of use, user-friendliness, and user behavior. To ensure the effectiveness of learning content used in mobile and gamified applications, it was suggested that duly approved content material, i.e., written or pictorial by the concerned authorities, was observed from the literature. Whereas specified and authentic learning content was missing, and desired learning outcomes were not achieved. More work is needed concerning teachers' professional development and exploration of their competencies in the field of MALL. The teacher-student relationship was inevitable regarding the teachinglearning process because it was the only source of incorporating various teaching methods and techniques to make learning effective [109]. In this regard, to compete for the world, teachers must link up with technological devices and gamified applications to engage their students in learning and entertainment to achieve a high learning outcome [110].

857 The applications used for learning did not fulfill the requirements related to usability, usefulness, effectiveness, ease of use, user-friendliness, and user behavior, so it is proposed to develop gamified applications (serious game) having all features supporting the above constructs. From

860 the literature review, a gamified application for English language learning at the primary level was lacking. Students of primary class levels loved to play more than indulging in books. A

862

863 conventional environment made the students passive in the class and lessened their motivation level.

864 During the literature review, research work regarding development of gamified application for reading comprehension was lacking. No such conceptual model gamification has been developed which may be used for language learning with reference to cultural context. Assessment of grammar or vocabulary in MALL applications were found during literature review but were not as such advanced enough that might perform personalized assessment of students' learning outcomes. Same was found in case of reward system and entertainment elements.

870 Therefore, gamified learning applications may be designed for primary grade students to make language learning more enjoyable, entertaining, attractive, and engaging them to achieve high

872 learning outcomes effectively.

\section{CONCLUSION:}


874 This systematic literature review aimed to understand research patterns in MALL to learn the

875 English language through mobile or gamified applications, approaches, and frameworks/models

876 developed, or adopted. A comprehensive analysis of literature was undertaken to ensure a

877 detailed discussion of the problems and their remedies. It was searched with as many known

878 terminologies associated with MALL and then analyzed the results accordingly. The search was

879 ended in August 2020, which would not have comprised studies that were carried out after the

880 date. The Web of Science core collection was analyzed, and 63 out of 57,364 publications were

881 selected.

882 The findings shown that nearly every selected article was published in a recognized journal,

883 whereas only single research at a conference. The two primary forms of study adopted in these

884 studies were "Solution Proposal" and "evaluation research." The majority of the chosen

885 researches were evidence-based and could lead to the full advantages of MALL to teachers and

886 students. MALL's most frequent key aspects were language learning strategies and evaluation of

887 students' results. In contrast, MALL specific frameworks and theories, approved content were

888 less addressed aspect of MALL.

889 The deficiencies in SLR related explicitly were research technique, incorrect data collection, or

890 misclassification. However, with separate keywords from the Web of Science core collection

891 repository, the research approach minimized the possibility of selection error. External concerns

892 were addressed by implementing specific inclusion/exclusion guidelines, and two independent

893 experts were requested to evaluate all extractions.

894 For future research on MALL, more attention might be paid to primary or secondary school

895 students and teachers, approved curricula design for English subject, and tools' design,

896 particularly serious games. Further evaluation research might be conducted to analyze existing

897 MALL content.

\section{ACKNOWLEDGEMENT}

899 The author acknowledged the financial support provided by Universiti Kebangsaan Malaysia for 900 this research and the School Education Department of Punjab, Pakistan, and Ms. Samia Ishaq, 901 Senior Headmistress, Government Girls High School, Kot Sondha, for helping throughout this 902 research.

\section{REFERENCES}

904 [1] J. Cheon, S. Lee, S. M. Crooks, and J. Song, "An investigation of mobile learning readiness in higher education

905

906

907

908

909

910

911

912

913

914

915

916

917 based on the theory of planned behavior," Computers \& Education, vol. 59, no. 3, pp. 1054-1064, 2012.

[2] M. Kearney, S. Schuck, K. Burden, and P. Aubusson, "Viewing mobile learning from a pedagogical perspective," Research in Learning Technology, vol. 20, no. 1, p. 14406, 2012.

[3] F. Martin and J. Ertzberger, "Here and now mobile learning: An experimental study on the use of mobile technology," Computers \& Education, vol. 68, pp. 76-85, 2013.

[4] Y. Liu, H. Li, and C. Carlsson, "Factors driving the adoption of m-learning: An empirical study," Computers \& Education, vol. 55, no. 3, pp. 1211-1219, 2010.

[5] J. Sandberg, M. Maris, and K. D. Geus, "Mobile English learning: An evidence-based study with fifth graders," Computers \& Education, vol. 57, no. 1, pp. 1334-1347, 2011.

[6] C.-K. Hsu, G.-J. Hwang, and C.-K. Chang, "A personalized recommendation-based mobile learning approach to improving the reading performance of EFL students," Computers \& Education, vol. 63, pp. 327-336, 2013.

[7] L.-H. Wong and C.-K. Looi, "Vocabulary learning by mobile-assisted authentic content creation and social meaning-making: two case studies," Journal of Computer Assisted Learning, vol. 26, no. 5, pp. 421-433, 2010.

Peer] Comput. Sci. reviewing PDF | (CS-2021:02:57961:1:1:NEW 17 Mar 2021) 
918

919

920

921

922

923

924

925

926

927

928

929

930

931

932

933

934

935

936

937

938

939

940

941

942

943

944

945

946

947

948

949

950

951

952

953

954

955

956

957

958

959

960

961

962

963

964

965

966

967
[8] C. L. Holden and J. M. Sykes, "Leveraging Mobile Games for Place-Based Language Learning," International Journal of Game-Based Learning, vol. 1, no. 2, pp. 1-18, 2011.

[9] H. Zhang, W. Song, and J. Burston, "Reexamining the effectiveness of vocabulary learning via mobile phones," Turkish Online Journal of Educational Technology-TOJET, vol. 10, no. 3, 2011

[10] J. Sandberg, M. Maris, and P. Hoogendoorn, "The added value of a gaming context and intelligent adaptation for a mobile learning application for vocabulary learning," Computers \& Education, vol. 76, pp. 119-130, 2014.

[11] C. S. Huang, S. J. Yang, T. H. Chiang, and A. Y. Su, "Effects of situated mobile learning approach on learning motivation and performance of EFL students," Journal of Educational Technology \& Society, vol. 19, no. 1, 2016.

[12] C.-C. Lin, "Learning English reading in a mobile-assisted extensive reading program," Computers \& Education, vol. 78, pp. 48-59, 2014.

[13] R.-T. Huang, S.-J. Jang, K. Machtmes, and D. Deggs, "Investigating the roles of perceived playfulness, resistance to change and self-management of learning in mobile English learning outcome," British Journal of Educational Technology, vol. 43, no. 6, pp. 1004-1015, 2011.

[14] R. Dashtestani, "Moving bravely towards mobile learning: Iranian students use of mobile devices for learning English as a foreign language," Computer Assisted Language Learning, vol. 29, no. 4, pp. 815-832, 2015.

[15] P.-L. Liu and C.-J. Chen, "Learning English through actions: a study of mobile-assisted language learning," Interactive Learning Environments, vol. 23, no. 2, pp. 158-171, 2014.

[16] D. Liakin, W. Cardoso, and N. Liakina, "Learning L2 pronunciation with a mobile speech recognizer: French /y/," CALICO Journal, vol. 32, no. 1, pp. 1-25, 2014.

[17] V. P. Dennen and S. Hao, "Intentionally mobile pedagogy: the M-COPE framework for mobile learning in higher education," Technology, Pedagogy and Education, vol. 23, no. 3, pp. 397-419, 2014.

[18] L. H. Wong, "Analysis of students' after-school mobile-assisted artifact creation processes in a seamless language learning environment,", Journal of Educational Technology \& Society, vol. 16, no. 2, 2013.

[19] S. Bohm and G. P. Constantine, "Impact of contextuality on mobile learning acceptance," Interactive Technology and Smart Education, vol. 13, no. 2, 2016.

[20] T.-T. Wu, "Improving the effectiveness of English vocabulary review by integrating ARCS with mobile gamebased learning," Journal of Computer Assisted Learning, vol. 34, no. 3, pp. 315-323, 2018.

[21] R. T. Huang, "Exploring the moderating role of self-management of learning in mobile English learning," Journal of Educational Technology \& Society, vol. 17, no. 4, 2014.

[22] C. Lai and D. Zheng, "Self-directed use of mobile devices for language learning beyond the classroom," ReCALL, vol. 30, no. 3, pp. 299-318, 2017.

[23] H. Avci and T. Adiguzel, "A Case Study on Mobile-Blended Collaborative Learning in an English as a Foreign Language (EFL) Context," The International Review of Research in Open and Distributed Learning, vol. 18, no. 7, 2017.

[24] C.-C. Chang, K.-H. Tseng, C. Liang, and C.-F. Yan, "The influence of perceived convenience and curiosity on continuance intention in mobile English learning for high school students using PDAs," Technology, Pedagogy and Education, vol. 22, no. 3, pp. 373-386, 2013.

[25] Z. Elgün-Gündüz, S. Akcan, and Y. Bayyurt, "Isolated form-focused instruction and integrated form-focused instruction in primary school English classrooms in Turkey," Language, Culture and Curriculum, vol. 25, no. 2, pp. 157-171, 2012.

[26] M. Amer, "A Study of Learners' Usage of a Mobile Learning Application for Learning Idioms and Collocations," CALICO Journal, vol. 31, no. 3, pp. 285-302, 2014.

[27] S. A. Petersen, E. Procter-Legg, and A. Cacchione, "Creativity and Mobile Language Learning Using LingoBee," International Journal of Mobile and Blended Learning, vol. 5, no. 3, pp. 34-51, 2013.

[28] C.-H. Tsai, C.-H. Cheng, D.-Y. Yeh, and S.-Y. Lin, "Can learning motivation predict learning achievement? A case study of a mobile game-based English learning approach," Education and Information Technologies, vol. 22, no. 5, pp. 2159-2173, 2016.

[29] D. Kim, D. Ruecker, and D.-J. Kim, "Mobile Assisted Language Learning Experiences," International Journal of Mobile and Blended Learning, vol. 9, no. 1, pp. 49-66, 2017.

Peer] Comput. Sci. reviewing PDF | (CS-2021:02:57961:1:1:NEW 17 Mar 2021) 
968

969

970

971

972

973

974

975

976

977

978

979

980

981

982

983

984

985

986

987

988

989

990

991

992

993

994

995

996

997

998

999

1000

1001

1002

1003

1004

1005

1006

1007

1008

1009

1010

1011

1012

1013

1014

1015

1016

1017

1018
[30] D. Wang, B. Zou, and M. Xing, "Vocabulary Learning and Consolidation with Mobile Application," International Journal of Computer-Assisted Language Learning and Teaching, vol. 4, no. 1, pp. 101-112, 2014.

[31] F. Teng, "Incidental vocabulary learning for primary school students: the effects of L2 caption type and word exposure frequency," The Australian Educational Researcher, vol. 46, no. 1, pp. 113-136, 2018.

[32] G. G. Botero, F. Questier, and C. Zhu, "Self-directed language learning in a mobile-assisted, out-of-class context: do students walk the talk?," Computer Assisted Language Learning, vol. 32, no. 1-2, pp. 71-97, 2018.

[33] C. Yurdagül and S. Öz, "Attitude towards Mobile Learning in English Language Education," Education Sciences, vol. 8, no. 3, p. 142, 2018.

[34] R. Gafni, D. B. Achituv, and G. Rahmani, "Learning Foreign Languages Using Mobile Applications," Journal of Information Technology Education: Research, vol. 16, pp. 301-317, 2017.

[35] S. Zhang, "Mobile English Learning: An Empirical Study on an APP, English Fun Dubbing," International Journal of Emerging Technologies in Learning (iJET), vol. 11, no. 12, p. 4, 2016.

[36] S. Uematsu, "The effect of English learning in elementary school on students' English language development in junior high school," Journal of Asia TEFL, vol. 9, no. 4, 2012.

[37] X. L. Pham, T. H. Nguyen, and G. D. Chen, "Research Through the App Store: Understanding Participant Behavior on a Mobile English Learning App," Journal of Educational Computing Research, vol. 56, no. 7, pp. 1076-1098, 2017.

[38] F. Çakmak and G. Erçetin, "Effects of gloss type on text recall and incidental vocabulary learning in mobileassisted L2 listening," ReCALL, vol. 30, no. 1, pp. 24-47, 2017.

[39] R.-C. Shih, "The Effect of English for Specific Purposes (ESP) Learning-Language Lab versus Mobile-Assisted Learning," International Journal of Distance Education Technologies, vol. 15, no. 3, pp. 15-30, 2017.

[40] F. C. Ou-Yang and W.-C. V. Wu, "Using Mixed-Modality Vocabulary Learning on Mobile Devices," Journal of Educational Computing Research, vol. 54, no. 8, pp. 1043-1069, 2016.

[41] Z. Quan, "Introducing' mobile DDL (data-driven learning)' for vocabulary learning: an experiment for academic English," Journal of Computers in Education, vol. 3, no. 3, pp. 273-287, 2016.

[42] E. Tragant, A. Marsol, R. Serrano, and À. Llanes, "Vocabulary learning at primary school: a comparison of EFL and CLIL," International Journal of Bilingual Education and Bilingualism, vol. 19, no. 5, pp. 579-591, 2015.

[43] T.-H. Chen and C.-C. Lin, "Enhancing L2 English Learning through Mobile-Assisted TBLT : EFL Learners' Perspectives," The Journal of AsiaTEFL, vol. 15, no. 2, pp. 453-461, 2018.

[44] B. Bouchaib, B. Ahmadou, and S. Abdelkader, "High School Students' Attributions of success in English Language Learning," International Journal of Instruction, vol. 11, no. 2, pp. 89-102, 2018.

[45] A. N. Hazaea and A. A. Alzubi, "Impact of Mobile Assisted Language Learning on Learner Autonomy in EFL Reading Context," Journal of Language and Education, vol. 4, no. 2, pp. 48-58, 2018.

[46] L. Kohnke, R. Zhang, and D. Zou, "Using Mobile Vocabulary Learning Apps as Aids to Knowledge Retention: Business Vocabulary Acquisition," The Journal of AsiaTEFL, vol. 16, no. 2, pp. 683-690, 2019.

[47] C.-M. Chen, H. Liu, and H.-B. Huang, "Effects of a mobile game-based English vocabulary learning app on learners' perceptions and learning performance: A case study of Taiwanese EFL learners," ReCALL, vol. 31, no. 2, pp. 170-188, 2019.

[48] C. Kirsch and A. B. Izuel, "Emergent multilinguals learning languages with the iPad app iTEO: a study in primary schools in Luxembourg," The Language Learning Journal, vol. 47, no. 2, pp. 204-218, 2017.

[49] K. Kalogirou, G. Beauchamp, and S. Whyte, "Vocabulary Acquisition via Drama: Welsh as a second language in the primary school setting," The Language Learning Journal, vol. 47, no. 3, pp. 332-343, 2017.

[50] M. Makoe and T. Shandu, "Developing a Mobile App for Learning English Vocabulary in an Open Distance Learning Context," The International Review of Research in Open and Distributed Learning, vol. 19, no. 4, 2018.

[51] M. Shahbaz and R. M. I. Khan "Use of mobile immersion in foreign language teaching to enhance target language vocabulary learning," MIER Journal of Educational Studies, Trends and Practices, vol. 7, no. 1, 2017.

[52] P. Fisser, J. Voogt, and M. Bom, "Word Score: A serious vocabulary game for primary school underachievers," Education and Information Technologies, vol. 18, no. 2, pp. 165-178, 2012. 
1019

1020

1021

1022

1023

1024

1025

1026

1027

1028

1029

1030

1031

1032

1033

1034

1035

1036

1037

1038

1039

1040

1041

1042

1043

1044

1045

1046

1047

1048

1049

1050

1051

1052

1053

1054

1055

1056

1057

1058

1059

1060

1061

1062

1063

1064

1065

1066

1067

1068

1069

1070

1071
[53] S. F. Ng, M. A. K. Azlan, A. N. A. Kamal, and A. Manion, "A quasi-experiment on using guided mobile learning interventions in ESL classrooms: Time use and academic performance," Education and Information Technologies, 2020.

[54] S. Bourekkache and O. Kazar, "Mobile and Adaptive Learning Application for English Language Learning," International Journal of Information and Communication Technology Education, vol. 16, no. 2, pp. 36-46, 2020.

[55] B. Klimova and P. Polakova, "Students' Perceptions of an EFL Vocabulary Learning Mobile Application," Education Sciences, vol. 10, no. 2, p. 37, 2020.

[56] N. Önal, K. K. Çevik, and V. Şenol, "The effect of SOS Table learning environment on mobile learning tools acceptance, motivation and mobile learning attitude in English language learning," Interactive Learning Environments, pp. 1-14, 2019.

[57] D. Zhang and P. Pérez-Paredes, "Chinese postgraduate EFL learners' self-directed use of mobile English learning resources," Computer Assisted Language Learning, pp. 1-26, 2019.

[58] H.C. Chu, C. C. Wang and L. Wang, "Impacts of Concept Map-Based Collaborative Mobile Gaming on English Grammar Learning Performance and Behaviors," Journal of Educational Technology \& Society, 2019.

[59] R. Ramadoss and Q. Wang, "Evaluation of a web-based assessment tool for learning grammar at the primary school level," International Journal of Continuing Engineering Education and Life-Long Learning, vol. 22, no. $3 / 4$, p. $175,2012$.

[60] K. Ishaq, N. Azan, F. Rosdi, A. Abid, and Q. Ali, "Usability of Mobile Assisted Language Learning App," International Journal of Advanced Computer Science and Applications, vol. 11, no. 1, 2020.

[61] K. Ishaq, N. Azan, F. Rosdi, A. Abid, and Q. Ali, "Usefulness of Mobile Assisted Language Learning in Primary Education," International Journal of Advanced Computer Science and Applications, vol. 11, no. 1, 2020.

[62] K. Ishaq, N. A. M. Zin, F. Rosdi, A. Abid, and U. Farooq, "Effectiveness of Literacy \& Numeracy Drive (LND): A Students Perspective," 2019 International Conference on Innovative Computing (ICIC), 2019.

[63] K. Ishaq, F. Rosdi, N. Azan, and A. Abid, "Usability and Design Issues of Mobile Assisted Language Learning Application," International Journal of Advanced Computer Science and Applications, vol. 11, no. 6, 2020.

[64] Y.-T. Sung, K.-E. Chang, and T.-C. Liu, "The effects of integrating mobile devices with teaching and learning on students learning performance: A meta-analysis and research synthesis," Computers \& Education, vol. 94, pp. 252-275, 2016.

[65] G.-J. Hwang and C.-C. Tsai, "Research trends in mobile and ubiquitous learning: a review of publications in selected journals from 2001 to 2010," British Journal of Educational Technology, vol. 42, no. 4, 2011.

[66] M. Liu, R. Scordino, R. Geurtz, C. Navarrete, Y. Ko, and M. Lim, "A look at research on mobile learning in K12 education from 2007 to the present," Journal of research on Technology in Education, vol. 46, no. 4, 2014.

[67] J. Burston, "Mobile-assisted language learning: A selected annotated bibliography of implementation studies 1994-2012," Language Learning \& Technology, vol. 17, no. 3, 2013.

[68] H. S. Mahdi, "Effectiveness of mobile devices on vocabulary learning: A meta-analysis," Journal of Educational Computing Research, vol. 56, no. 1, 2018.

[69] K. Cho, S. Lee, M.-H. Joo, and B. Becker, "The Effects of Using Mobile Devices on Student Achievement in Language Learning: A Meta-Analysis," Education Sciences, vol. 8, no. 3, p. 105, 2018.

[70] P. Brereton, B. A. Kitchenham, D. Budgen, M. Turner, and M. Khalil, 'Lessons from applying the systematic literature review process within the software engineering domain," J. Syst. Softw., vol. 80, no. 4, pp. 571_583, Apr. 2007.

[71] WoS. "Web of Science Core Collection" 25-Jun-2020. [Online]. Available: https:/clarivate.com/webofsciencegroup/solutions/web-of-science-core-collection/. [Accessed: 09-Sep-2020]

[72] "Web of Science (ISI) | Princeton University Library," Princeton University. [Online]. Available: https://library.princeton.edu/resource/4136. [Accessed: 31-Dec-2020].

[73] A. Fernandez, E. Insfran, and S. Abrah ao, “Usability evaluation methods for the Web: A systematic mapping study," Inf. Softw. Technol., vol. 53, no. 8, pp. 789_817, Aug. 2011.

[74] S. Ouhbi, A. Idri, J. L. Fernández-Alemán, and A. Toval, 'Requirements engineering education: A systematic mapping study," Requirements Eng., vol. 20, no. 2, pp. $119 \_138$, Jun. 2015.

[75] (2018). Scimago Journal \& Country Rank. Accessed: Sep. 10, 2020. [Online]. Available: https://www.scimagojr.com/

PeerJ Comput. Sci. reviewing PDF | (CS-2021:02:57961:1:1:NEW 17 Mar 2021) 
1072

1073

1074

1075

1076

1077

1078

1079

1080

1081

1082

1083

1084

1085

1086

1087

1088

1089

1090

1091

1092

1093

1094

1095

1096

1097

1098

1099

1100

1101

1102

1103

1104

1105

1106

1107

1108

1109

1110

1111

1112

1113

1114

1115

1116

1117

1118

1119

1120

1121

1122

1123

1124
[76] (2018). CORE Conference Portal. Accessed: Sep. 10, 2020. [Online]. Available: http://portal.core.edu.au/confranks/

[77] E. Mehmood, A. Abid, M. S. Farooq, and N. A. Nawaz, "Curriculum, Teaching and Learning, and Assessments for Introductory Programming Course," IEEE Access, vol. 8, pp. 125961-125981, 2020.

[78] Davis, F. D. (1989). Perceived usefulness, perceived ease of use, and user acceptance of information technology. MIS quarterly, 319-340.

[79] Paul D., "Research Support: Research Methodology,” LibGuides, 06-Nov-2000. [Online]. Available: https://libguides.wits.ac.za/c.php?g=693518\&p=4914913. [Accessed: 15-Sep-2020].

[80] M. Rouse, "What is statistical analysis? - Definition from WhatIs.com," WhatIs.com, 31-Aug-2020. [Online]. Available: https:/whatis.techtarget.com/definition/statistical-analysis. [Accessed: 15-Sep-2020].

[81] J. Wei, "What is a Statistical Mean? - Definition from Techopedia," Techopedia.com, 14-Aug-2020. [Online]. Available: https://www.techopedia.com/definition/26136/statistical-mean. [Accessed: 15-Sep-2020].

[82] M. Hargrave, "Standard Deviation," Investopedia, 17-Aug-2020. [Online]. Available: https://www.investopedia.com/terms/s/standarddeviation.asp. [Accessed: 15-Sep-2020].

[83] “ANOVA," Statistics Solutions, 2013. [Online]. Available: https://www.statisticssolutions.com/manovaanalysis-anova/. [Accessed: 15-Sep-2020].

[84] "t-test," Statistics Solutions, 2013. [Online]. Available: https://www.statisticssolutions.com/manova-analysisanova/. [Accessed: 15-Sep-2020].

[85] "ANCOVA," Statistics Solutions, 2013. [Online]. Available: https://www.statisticssolutions.com/manovaanalysis-anova/. [Accessed: 15-Sep-2020].

[86] "MANOVA," Statistics Solutions, 2013. [Online]. Available: https://www.statisticssolutions.com/manovaanalysis-anova/. [Accessed: 15-Sep-2020].

[87] "Linear Regression," Statistics Solutions, 2013. [Online]. Available: https://www.statisticssolutions.com/manova-analysis-anova/. [Accessed: 15-Sep-2020].

[88] J. Young, "Frequency Distribution," Investopedia, 03-Sep-2020. [Online]. Available: https://www.investopedia.com/terms/f/frequencydistribution.asp. [Accessed: 18-Sep-2020].

[89] P. byinfed.org, "What is teaching? A definition and discussion," infedorg, 24-Aug-2020. [Online]. Available: https://infed.org/mobi/what-is-teaching/. [Accessed: 23-Sep-2020].

[90] R. Harrison, D. Flood, and D. Duce, "Usability of mobile applications: literature review and rationale for a new usability model," Journal of Interaction Science, vol. 1, no. 1, p. 1, 2013.

[91] World Leaders in Research-Based User Experience, "Usability 101: Introduction to Usability," Nielsen Norman Group. [Online]. Available: https://www.nngroup.com/articles/usability-101-introduction-to-usability/. [Accessed: 29-Sep-2020].

[92] E. A. Peel, "Pedagogy," Encyclopcedia Britannica, 17-May-2017. [Online]. Available: https:/www.britannica.com/science/pedagogy. [Accessed: 29-Sep-2020].

[93] "MSG Management Study Guide," What is Motivation. [Online]. Available: https://www.managementstudyguide.com/what_is_motivation.htm. [Accessed: 29-Sep-2020].

[94] "Attitude: Definition, Nature and Characteristics (Explained)," iEduNote.com, 16-Apr-2020. [Online]. Available: https:/www.iedunote.com/attitude-definition-characteristics-types. [Accessed: 29-Sep-2020].

[95] "What is Self-Directed Learning," IGI Global. [Online]. Available: https://www.igi-global.com/dictionary/selfdirected-learning/26210. [Accessed: 29-Sep-2020].

[96] "Behavior pattern," Dictionary.com. [Online]. Available: https://www.dictionary.com/browse/behavior-pattern. [Accessed: 29-Sep-2020].

[97] "What is Learning Behaviour?," Northampton Centre for Learning Behaviour. [Online]. Available: http://www.ncflb.com/aboutus/learningbehaviour/. [Accessed: 29-Sep-2020].

[98] A. Hayes, "Scalability: What It Is, and How It Works," Investopedia, 16-Sep-2020. [Online]. Available: https:/www.investopedia.com/terms/s/scalability.asp. [Accessed: 29-Sep-2020].

[99] "What is Reliability?," $A S Q$. [Online]. Available: https://asq.org/quality-resources/reliability\#: :text=Reliability is defined as the, a defined environment without failure. [Accessed: 29-Sep-2020].

[100] "flexibility," flexibility noun - Definition, pictures, pronunciation and usage notes | Oxford Advanced Learner's Dictionary at OxfordLearnersDictionaries.com. [Online]. Available: https://www.oxfordlearnersdictionaries.com/definition/english/flexibility?q=Flexibility. [Accessed: 31-Dec2020].

Peer] Comput. Sci. reviewing PDF | (CS-2021:02:57961:1:1:NEW 17 Mar 2021) 
1125 [101] "Definitions for Affordance," What does Affordance mean? [Online]. Available:

1126

1127

1128

1129

1130

1131

1132

1133

1134

1135

1136

1137

1138

1139

1140

1141

1142

1143

1144

1145

1146

1147

1148

1149

1150

1151

1152

1153

1154

1155

1156

1157

1158

1159

1160 https://www.definitions.net/definition/Affordance. [Accessed: 29-Sep-2020].

[102] "perception," perception noun - Definition, pictures, pronunciation and usage notes | Oxford Advanced Learner's Dictionary at OxfordLearnersDictionaries.com. [Online]. Available: https://www.oxfordlearnersdictionaries.com/definition/english/perception. [Accessed: 31-Dec-2020].

[103] "Achievement definition and meaning: Collins English Dictionary," Achievement definition and meaning | Collins English Dictionary. [Online]. Available: https://www.collinsdictionary.com/dictionary/english/achievement. [Accessed: 30-Sep-2020].

[104] O. U. P. ELT, "Learner Autonomy," Oxford University Press, 14-Feb-2013. [Online]. Available: https://oupeltglobalblog.com/2013/01/29/learner-autonomy/. [Accessed: 30-Sep-2020].

[105] K. Ishaq, N. Azan, F. Rosdi, A. Abid, and Q. Ali, "Usefulness of Mobile Assisted Language Learning App," International Journal of Engineering and Advanced Technology (IJEAT), vol. 9, no. 3, 2020.

[106] C. Dichev and D. Dicheva, "Gamifying education: what is known, what is believed and what remains uncertain: a critical review," International Journal of Educational Technology in Higher Education, vol. 14, no. $1,2017$.

[107] S. Mcleod, "Lev Vygotsky's Sociocultural Theory," Lev Vygotsky's Sociocultural Theory | Simply Psychology. [Online]. Available: https://www.simplypsychology.org/vygotsky.html. [Accessed: 29-Nov-2020].

[108] "Instructional Theory Definition and Meaning," Top Hat, 16-Sep-2019. [Online]. Available: https://tophat.com/glossary/i/instructional-theory/. [Accessed: 29-Nov-2020].

[109] U. Omer, M. S., and A. Abid, "Cognitive learning analytics using assessment data and concept map: A framework-based approach for sustainability of programming courses", Sustainability, vol. 12, no. 17, 2020

[110] W. M. W. Isa, N. A. M. Zin, F. Rosdi and H. M. Sarim, "Serious Game Design for Terengganu Brassware Craft Heritage", IEEE Conference on Graphics and Media (GAME), Nov-2019

[111] N. Yanes and I. Bououd, "Using Gamification and Serious Games for English Language Learning," 2019 International Conference on Computer and Information Sciences (ICCIS), 2019.

[112] F. Angelia and Suharjito, "Improving English Learning through Game Using 6-11 MDA Framework," 2019 12th International Conference on Information \& Communication Technology and System (ICTS), 2019.

[113] P. Tshering, D. Norbu, S. Dorji, N. Dema, and P. R. Dhungyel, "Experience of a Gamified Spelling Solving by Students for Learning Spelling: Development of Kids Spell Dzongkha App.," 2018 International Conference on Current Trends towards Converging Technologies (ICCTCT), 2018.

[114] A. Krasulia and K. Saks, "Students' perceptions towards mobile learning in an English as a foreign language class," 2020 IEEE 20th International Conference on Advanced Learning Technologies (ICALT), 2020.

[115] N. A. M. Zin and W. S. Yue, "Design and Evaluation of History Digital Game Based Learning (DGBL) Software," Journal of Next Generation Information Technology, vol. 4, no. 4, pp. 9-24, 2013.

[116] N. A. M. Zin, A. Jaafar, \& W.S. Yue, "Digital game-based learning (DGBL) model and development methodology for teaching history," WSEAS transactions on computers, vol. 8, no. 2, pp. 322-333 2009. 


\section{Figure 1}

Research Strategy

\section{Stage 1:}

Planning the review

- Survey objectives specification

- Describing research questions

\section{Stage 2:}

Conducting the review

- Search in digital repositories

- Selection based on inclusion and exclusion method

- Selection based on quality assessment

- Selection based on snowballing

Stage 3:

- Reporting the review 
Figure 2

Search Strategy

Pexard
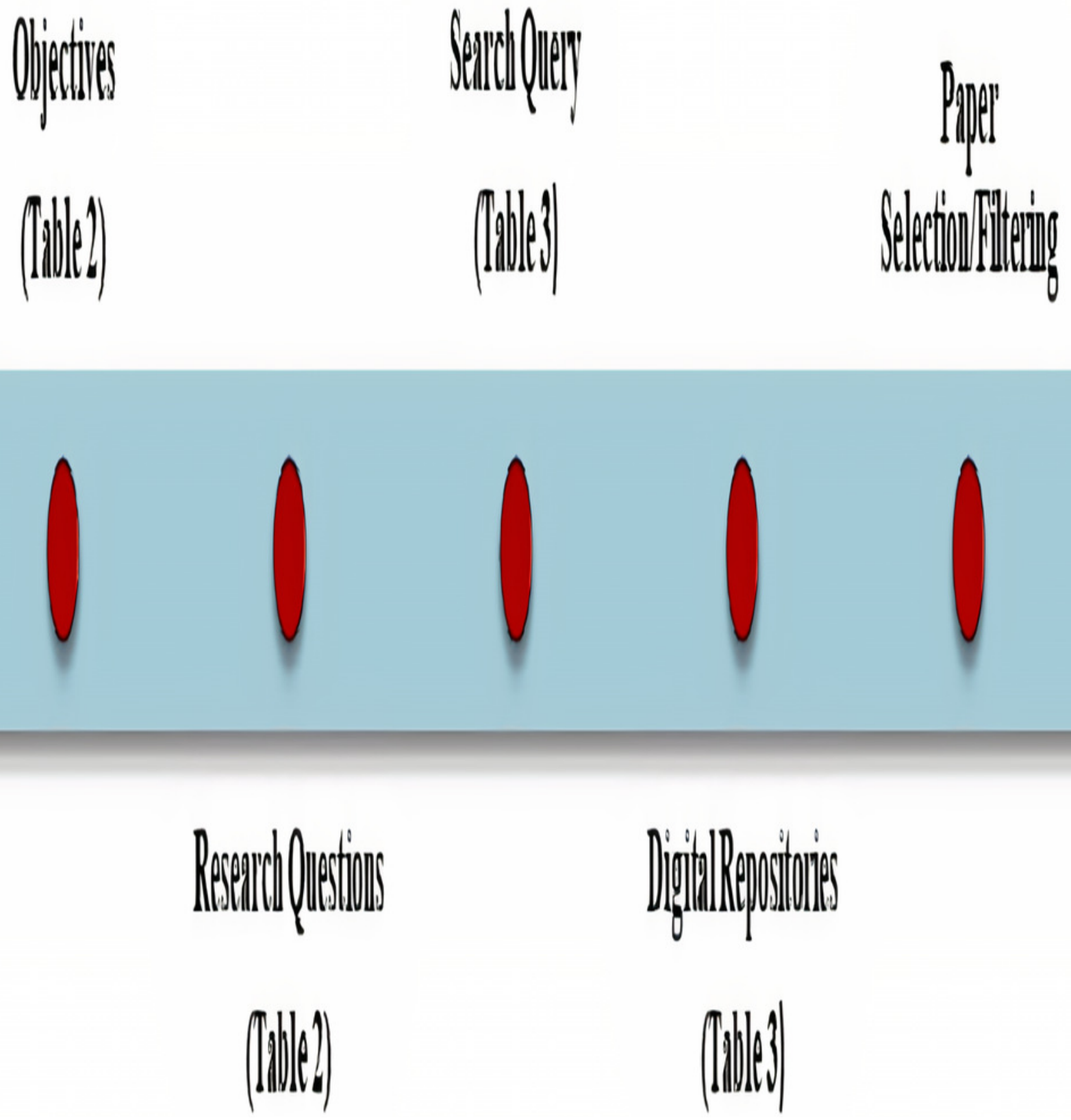


\section{Figure 3}

\section{Search Results}

\section{Citation reportfor 3,897 results from Web of Science Core Collection between 2010 v and 2020 V 60}

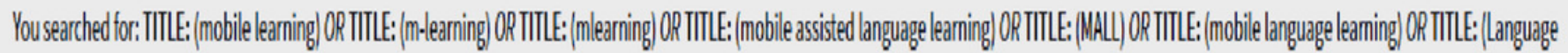

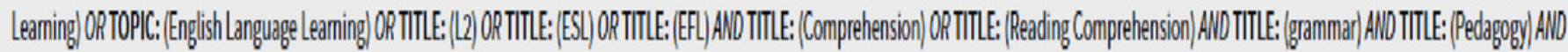

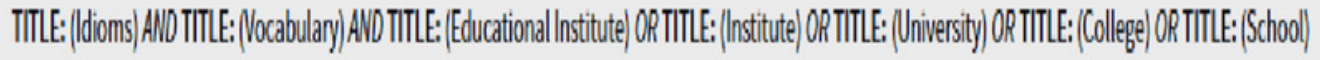

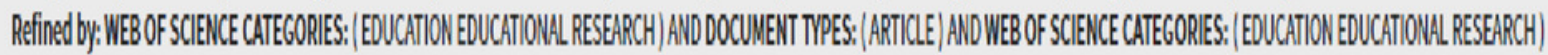

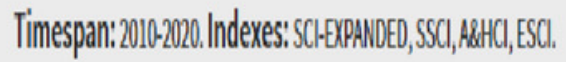

...ess

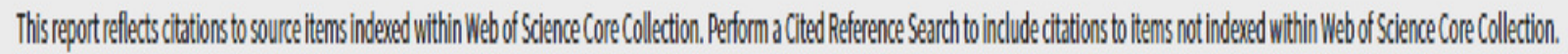

Export Data: SavetoExcelFile

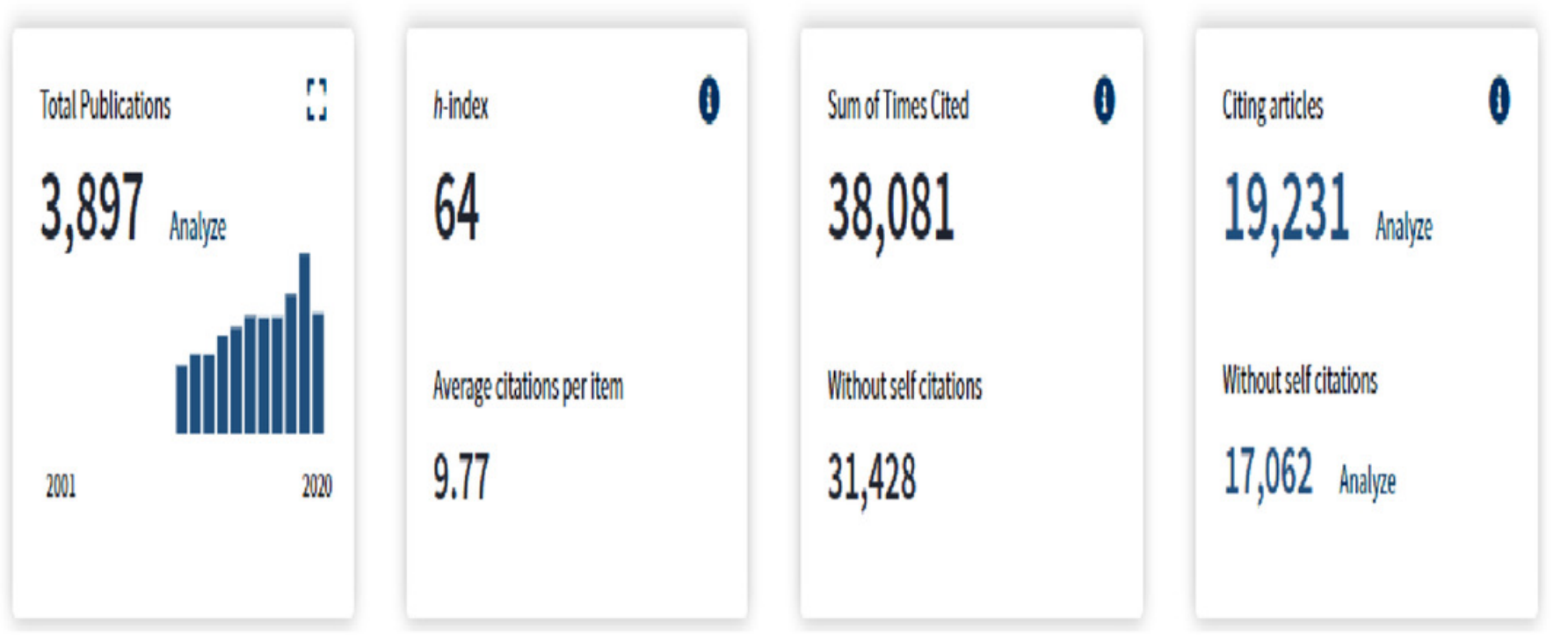


Figure 4

Selection of relevant articles using Systematic Review Process

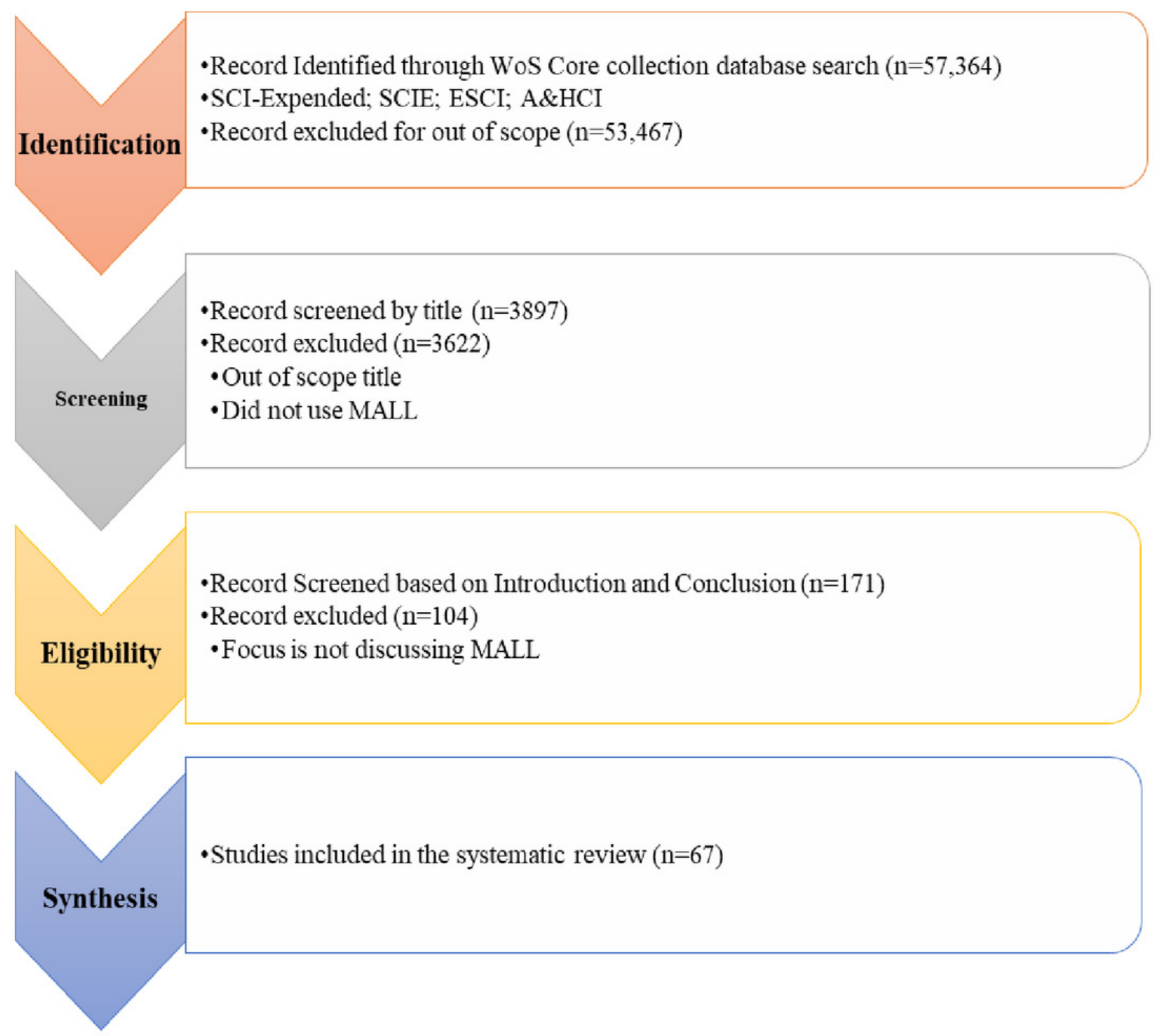


Figure 5

Graph of identified studies by year

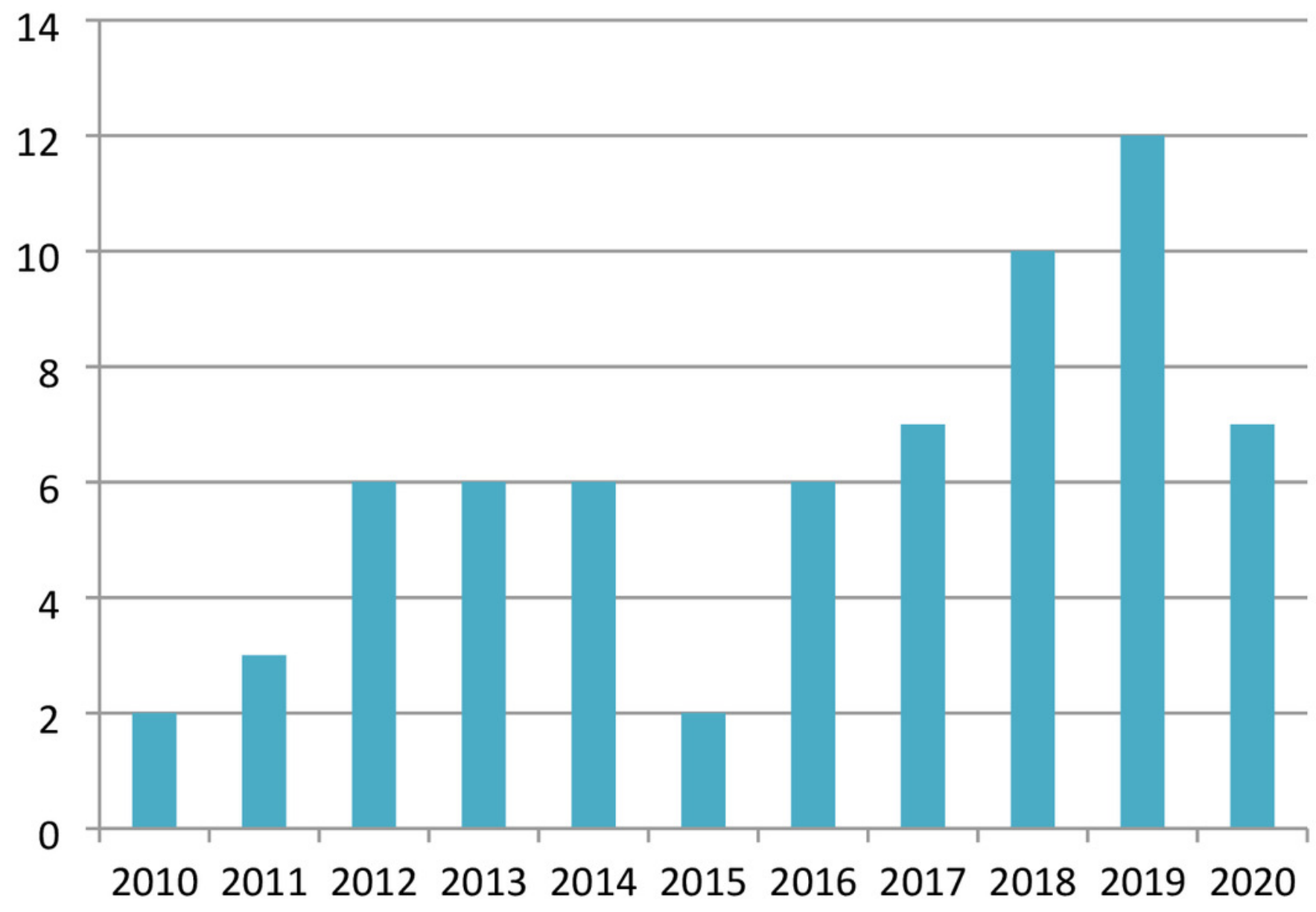




\section{Figure 6}

Graph of identified studies by continent

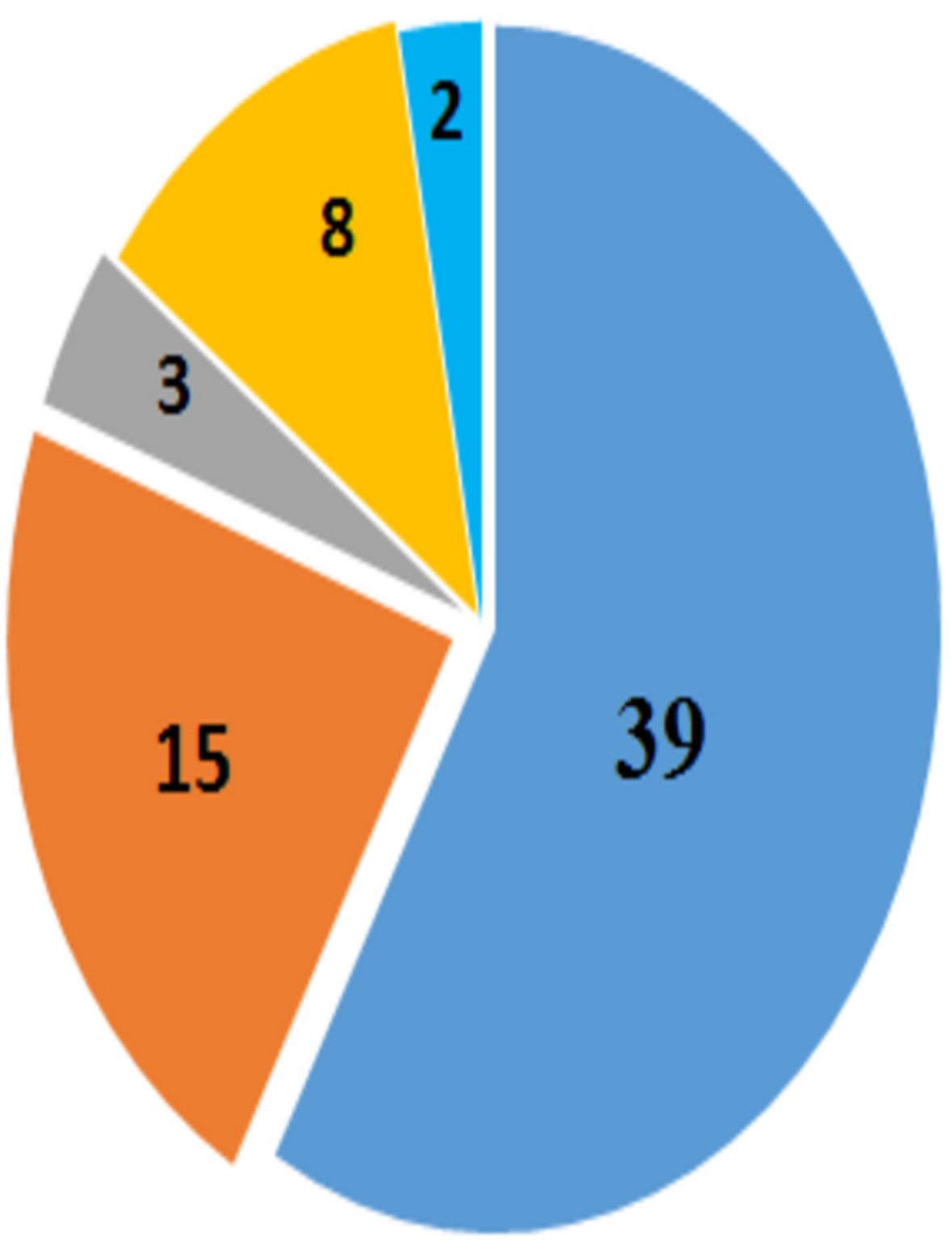

Asia

Europe

Africa

North America

Ocean-continent 
Figure 7

Graph of MALL and Gamified Application

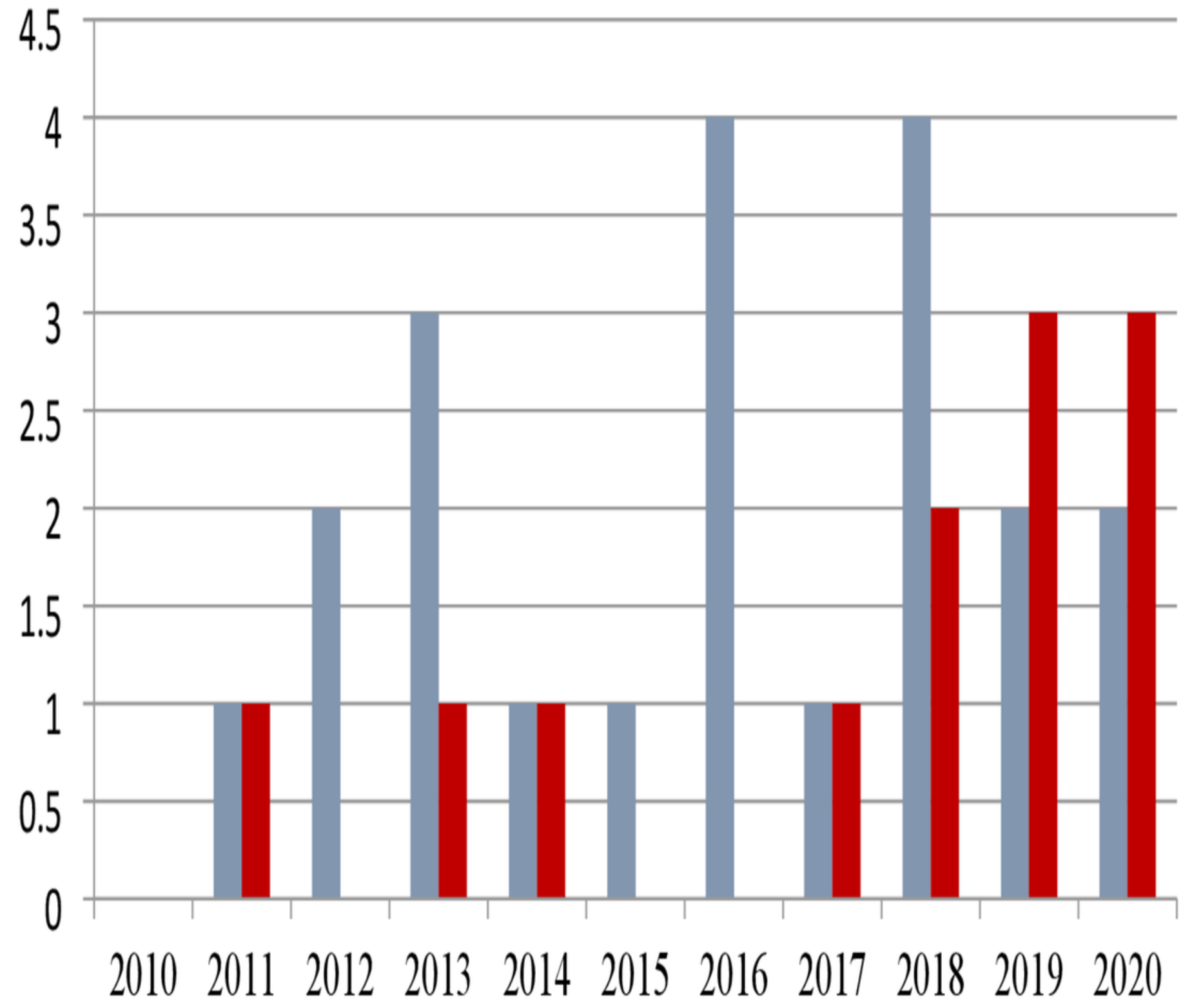


Figure 8

Taxonomy of MALL and gamified apps

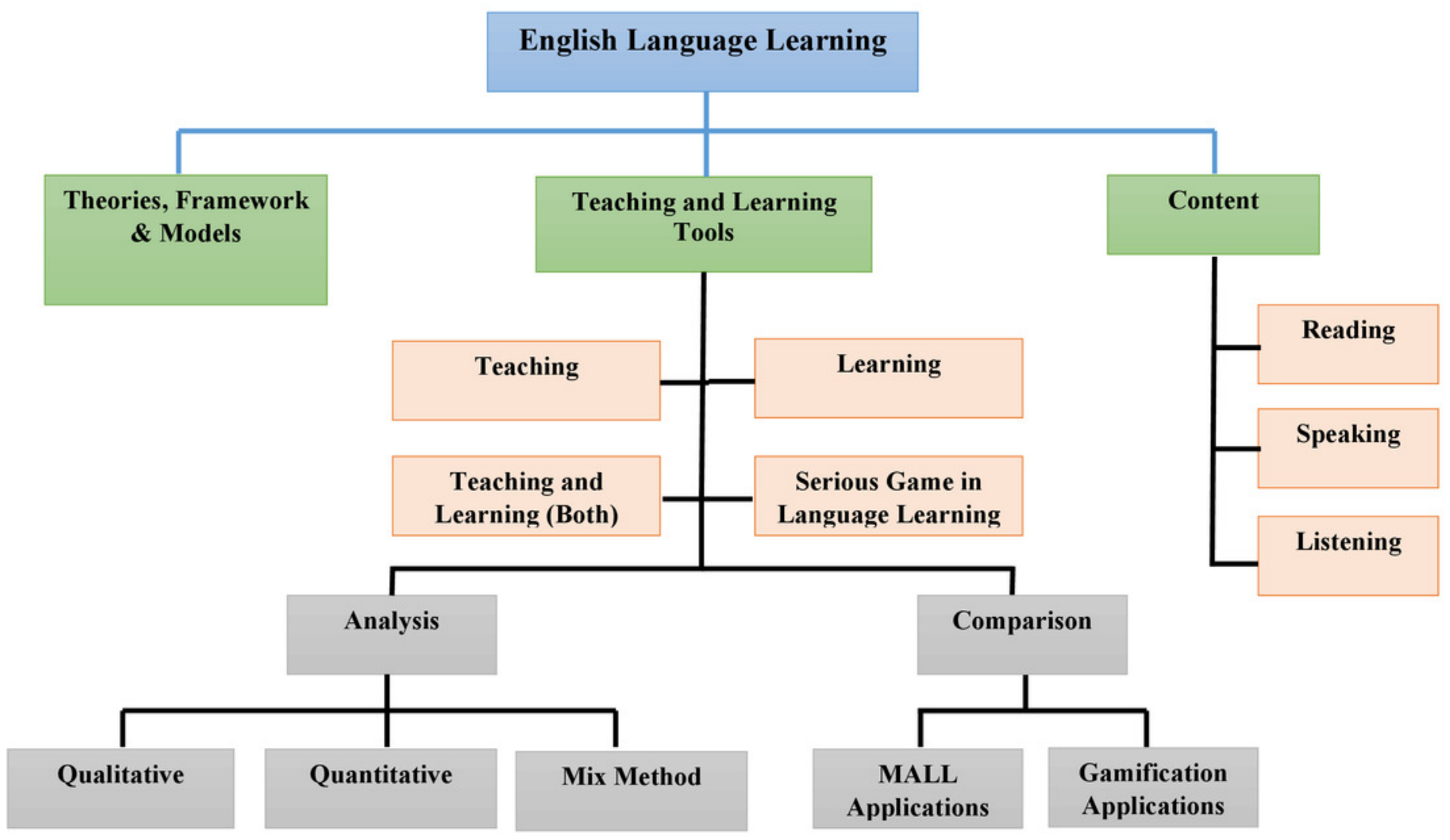




\section{Table $\mathbf{1}$ (on next page)}

Related work comparison 
Table 1. Related work comparison

\begin{tabular}{|c|c|c|c|c|c|c|c|}
\hline Ref. & Title Survey & $\begin{array}{c}\text { Survey } \\
\text { Approach }\end{array}$ & $\begin{array}{c}\text { Quality } \\
\text { Assessme } \\
\text { nt }\end{array}$ & $\begin{array}{l}\text { Research } \\
\text { Framewor } \\
\mathbf{k}\end{array}$ & $\begin{array}{l}\text { Teachin } \\
\text { g and } \\
\text { Learnin } \\
\text { g Tools }\end{array}$ & Content & $\begin{array}{l}\text { Targeted Digital } \\
\text { Repositories }\end{array}$ \\
\hline$[65]$ & $\begin{array}{l}\text { Research trends and Prediction of technology-based } \\
\text { learning with the latest technology (i.e., devices or } \\
\text { concepts) }\end{array}$ & Informal & $\times$ & $x$ & $\sqrt{ }$ & $x$ & SSCI \\
\hline [67] & $\begin{array}{l}\text { MOBILE-ASSISTED LANGUAGE LEARNING: A } \\
\text { SELECTED ANNOTATED BIBLIOGRAPHY OF } \\
\text { IMPLEMENTATION STUDIES 1994-2012 }\end{array}$ & Informal & $x$ & $x$ & $\sqrt{ }$ & $\sqrt{ }$ & Google Scholar \\
\hline [66] & $\begin{array}{l}\text { A Look at Research on Mobile Learning in K-12 } \\
\text { Education From } 2007 \text { to the Present }\end{array}$ & $\begin{array}{l}\text { Systematic } \\
\text { Search }\end{array}$ & $x$ & $x$ & $\sqrt{ }$ & $\sqrt{ }$ & 15 Journals \\
\hline [64] & $\begin{array}{l}\text { The effects of integrating mobile devices with teaching } \\
\text { and learning on students' learning performance: A meta- } \\
\text { analysis and research synthesis }\end{array}$ & $\begin{array}{l}\text { Systematic } \\
\text { Search }\end{array}$ & $x$ & $x$ & $\sqrt{ }$ & $x$ & $\begin{array}{l}\text { ERIC, EBSCOhost, } \\
\text { PsycINFO, JSTOR, and } \\
\text { ProQuest }\end{array}$ \\
\hline [68] & $\begin{array}{l}\text { Effectiveness of Mobile Devices on Vocabulary } \\
\text { Learning: A Meta-Analysis }\end{array}$ & $\begin{array}{l}\text { Systematic } \\
\text { Search and } \\
\text { Snowballing }\end{array}$ & $x$ & $x$ & $\sqrt{ }$ & $x$ & $\begin{array}{l}\text { ERIC, IEEE Xplore, } \\
\text { IGI, Proquest, Sage, } \\
\text { ScienceDirect, and } \\
\text { Springer Link }\end{array}$ \\
\hline [69] & $\begin{array}{l}\text { The Effects of Using Mobile Devices on Student } \\
\text { Achievement in Language Learning: A Meta-Analysis }\end{array}$ & $\begin{array}{l}\text { Systematic } \\
\text { Search and } \\
\text { Snowballing }\end{array}$ & $\times$ & $\sqrt{ }$ & $\times$ & $x$ & ERIC, SSCI \\
\hline $\begin{array}{l}\text { This } \\
\text { Study }\end{array}$ & $\begin{array}{l}\text { Mobile-Assisted and Gamification-based Language } \\
\text { Learning: A Systematic Literature Review }\end{array}$ & $\begin{array}{c}\text { Systematic } \\
\text { Search, } \\
\text { Snowballing } \\
\text {, and } \\
\text { Quality } \\
\text { Assessment }\end{array}$ & $\sqrt{ }$ & $\sqrt{ }$ & $\sqrt{ }$ & $\sqrt{ }$ & $\begin{array}{l}\text { WoS Core Collection } \\
\text { (High quality, more than } \\
\text { ten rep.) }\end{array}$ \\
\hline
\end{tabular}




\section{Table 2 (on next page)}

Research Questions (RQs) 
Table 2: Research Questions (RQs)

\begin{tabular}{|c|c|c|}
\hline (RQ) & RQ Statement & Objectives and Motivation \\
\hline RQ1: & $\begin{array}{l}\text { What were the high-quality publication } \\
\text { channels for MALL research, and which } \\
\text { geographical areas have been targeting } \\
\text { MALL research over the years? }\end{array}$ & $\begin{array}{l}\text { The objectives of RQ1 were to search for high- } \\
\text { quality research articles through major } \\
\text { publications channels for MALL research. } \\
\text { Furthermore, the quality assessment for the } \\
\text { selected articles and the meta-information } \\
\text { extracted useful statistics, including the } \\
\text { geographical areas and publication, trended over } \\
\text { the years. }\end{array}$ \\
\hline RQ2: & $\begin{array}{l}\text { What were the widely used theories, models, } \\
\text { and frameworks proposed or adopted for } \\
\text { MALL research? }\end{array}$ & $\begin{array}{l}\text { To identify the theories and } \\
\text { frameworks/conceptual models used for MALL } \\
\text { research and related them to different application } \\
\text { areas for MALL. }\end{array}$ \\
\hline RQ3: & $\begin{array}{l}\text { What were different application domains for } \\
\text { the MALL application, and in which various } \\
\text { forms were these applications exposed for } \\
\text { the end-users? }\end{array}$ & $\begin{array}{l}\text { To identify different target application areas of } \\
\text { MALL from teaching and learning perspectives. } \\
\text { Furthermore, identify different modes of } \\
\text { exposition for these MALL applications. }\end{array}$ \\
\hline RQ4: & $\begin{array}{l}\text { What was the specific content adopted for } \\
\text { teaching and learning in MALL research? }\end{array}$ & $\begin{array}{l}\text { To accommodate different contents for MALL } \\
\text { applications focusing on reading, writing, } \\
\text { speaking, and listening perspectives. }\end{array}$ \\
\hline RQ5: & $\begin{array}{l}\text { How and in what different perspectives the } \\
\text { MALL applications were evaluated, and what } \\
\text { were the evaluation measures and tools used } \\
\text { for their evaluation? }\end{array}$ & $\begin{array}{l}\text { Outline the standard process, tools, and } \\
\text { instruments used for the evaluation of MALL } \\
\text { applications. Furthermore, identify the } \\
\text { evaluation measures for MALL applications } \\
\text { concerning different perspectives, including } \\
\text { teaching and learning and technical perspectives. }\end{array}$ \\
\hline RQ6: & $\begin{array}{l}\text { Compare the usage of simple mobile } \\
\text { applications with gamified applications } \\
\text { (Serious Game) for language learning? }\end{array}$ & $\begin{array}{l}\text { To perform a comparative analysis to evaluate } \\
\text { the effectiveness of simple mobile application- } \\
\text { based language learning with gamified mobile } \\
\text { applications for language learning. }\end{array}$ \\
\hline
\end{tabular}




\section{Table 3 (on next page)}

Digital Library Search Strategy 
Table 3. Digital Library Search Strategy

\begin{tabular}{|c|c|c|}
\hline $\begin{array}{l}\text { Digital } \\
\text { Library }\end{array}$ & Search Query & $\begin{array}{l}\text { Applied } \\
\text { Filter }\end{array}$ \\
\hline $\begin{array}{l}\text { (WoS Core } \\
\text { Collection) } \\
\text { SCI- } \\
\text { Expended } \\
\text { SCIE } \\
\text { ESCI } \\
\text { A\&HCI }\end{array}$ & $\begin{array}{l}\text { TITLE: (mobile learning) OR TITLE: (m-learning) OR } \\
\text { TITLE: (m-learning) OR TITLE: (mobile assisted } \\
\text { language learning) OR TITLE: (MALL) OR TITLE: } \\
\text { (mobile language learning) OR TITLE: (Language } \\
\text { Learning) OR TITLE: (English Language Learning) OR } \\
\text { TITLE: (L2) OR TITLE: (ESL) OR TITLE: (EFL) AND } \\
\text { TITLE: (Comprehension) OR TITLE: (Reading } \\
\text { Comprehension) AND TITLE: (grammar) AND TITLE: } \\
\text { (Pedagogy) AND TITLE: (Idioms) AND TITLE: } \\
\text { (Vocabulary) AND TITLE: (Educational Institute) OR } \\
\text { TITLE: (Institute) OR TITLE: (University) OR TITLE: } \\
\text { (College) OR TITLE: (School) OR TITLE: (Elementary } \\
\text { School) OR TITLE: (Primary School) Defining }\end{array}$ & \\
\hline
\end{tabular}




\section{Table 4 (on next page)}

Rating for stable and recognized publication sources 
Table 4: Rating for stable and recognized publication sources

\begin{tabular}{|c|c|c|c|c|c|c|}
\hline $\begin{array}{c}\text { Item. } \\
\text { No. }\end{array}$ & Publication Source & $\mathbf{+ 4}$ & $\mathbf{+ 3}$ & $\mathbf{+ 2}$ & $\mathbf{+ 1}$ & $\mathbf{+ 0}$ \\
\hline 1 & Journals & $\mathrm{Q} 1$ & $\mathrm{Q} 2$ & $\mathrm{Q} 3$ & $\mathrm{Q} 4$ & $\begin{array}{c}\text { No JCR } \\
\text { Ranking }\end{array}$ \\
\hline 2 & Conferences & Core A $*$ & Core A & Core B & Core C & $\begin{array}{c}\text { Not in Core } \\
\text { Ranking }\end{array}$ \\
\hline
\end{tabular}

2 


\section{Table 5 (on next page)}

Selection Phases and Results 
1

Table 5. Selection Phases and Results:

\begin{tabular}{|c|c|c|c|}
\hline Phase & Selection & Selection Criteria & $\begin{array}{c}\text { Indexes: } \\
\text { SCI-EXPANDED, SSCI, A\&HCI, } \\
\text { ESCI }\end{array}$ \\
\hline 1 & Search & Keywords (Figure) & 57,364 \\
\hline 2 & Filtering & Title & 3,897 \\
\hline 3 & Filtering & Abstract & 275 \\
\hline 4 & Filtering & Introduction and Conclusion & 167 \\
\hline 5 & Inspection & Full Article & 67 \\
\hline
\end{tabular}

2 


\section{Table 6 (on next page)}

Identified publications by year 
1

Table 6. Identified publications by year

\begin{tabular}{|c|c|c|c|c|c|c|c|c|c|c|c|c|}
\hline Year & $\mathbf{2 0 1 0}$ & $\mathbf{2 0 1 1}$ & $\mathbf{2 0 1 2}$ & $\mathbf{2 0 1 3}$ & $\mathbf{2 0 1 4}$ & $\mathbf{2 0 1 5}$ & $\mathbf{2 0 1 6}$ & $\mathbf{2 0 1 7}$ & $\mathbf{2 0 1 8}$ & $\mathbf{2 0 1 9}$ & $\mathbf{2 0 2 0}$ & Total \\
\hline $\begin{array}{c}\text { Number of } \\
\text { Publication }\end{array}$ & 2 & 3 & 6 & 6 & 6 & 2 & 6 & 7 & 10 & 12 & 7 & 67 \\
\hline
\end{tabular}

2 


\section{Table 7(on next page)}

Publications by geographic areas 
Table 7. Publications by geographic areas

2

\begin{tabular}{|c|c|c|c|}
\hline $\begin{array}{l}\text { Item } \\
\text { No. }\end{array}$ & Sub-Continent & Countries & $\begin{array}{l}\text { Number of } \\
\text { Publication }\end{array}$ \\
\hline \multirow{12}{*}{1} & \multirow{12}{*}{ Asia } & Taiwan & 14 \\
\hline & & Turkey & 5 \\
\hline & & Malaysia & 4 \\
\hline & & Hong Kong & 3 \\
\hline & & Singapore & 3 \\
\hline & & China & 2 \\
\hline & & Saudi Arab & 3 \\
\hline & & Pakistan & 1 \\
\hline & & Japan & 1 \\
\hline & & Iran & 1 \\
\hline & & India & 1 \\
\hline & & Israel & 1 \\
\hline \multirow{10}{*}{2} & \multirow{10}{*}{ Europe } & Netherland & 3 \\
\hline & & UK & 3 \\
\hline & & Czech Republic & 1 \\
\hline & & France & 1 \\
\hline & & Luxembourg & 1 \\
\hline & & Spain & 1 \\
\hline & & Belgium & 1 \\
\hline & & Norway & 1 \\
\hline & & Germany & 1 \\
\hline & & Estonia & 2 \\
\hline \multirow{3}{*}{3} & \multirow{3}{*}{ Africa } & Algeria & 1 \\
\hline & & South Africa & 1 \\
\hline & & Morocco & 1 \\
\hline \multirow{2}{*}{4} & \multirow{2}{*}{ North America } & US & 7 \\
\hline & & Canada & 1 \\
\hline \multirow{2}{*}{5} & \multirow{2}{*}{ Ocean-continent } & New Zealand & 1 \\
\hline & & Australia & 1 \\
\hline \multicolumn{3}{|c|}{ Total } & 67 \\
\hline
\end{tabular}




\section{Table 8 (on next page)}

\section{Publication Sources}


Table 8. Publication Sources

\begin{tabular}{|c|c|c|c|}
\hline $\begin{array}{l}\text { Item } \\
\text { No. }\end{array}$ & Publication Source & Channel & $\begin{array}{l}\text { No. of } \\
\text { Articles }\end{array}$ \\
\hline 1 & Computers \& Education & Journal & 7 \\
\hline 2 & Educational Technology \& Society & Journal & 4 \\
\hline 3 & Computer-Assisted Language Learning & Journal & 3 \\
\hline 4 & Recall & Journal & 3 \\
\hline 5 & Education and Information Technologies & Journal & 3 \\
\hline 6 & Journal of Asia TEFL & Journal & 3 \\
\hline 7 & International Journal of Advanced Computer Science and Applications & Journal & 3 \\
\hline 8 & Journal of Computer Assisted Learning & Journal & 2 \\
\hline 9 & Interactive Learning Environments & Journal & 2 \\
\hline 10 & CALICO Journal & Journal & 2 \\
\hline 11 & Technology Pedagogy and Education & Journal & 2 \\
\hline 12 & International Review of Research in Open and Distributed Learning & Journal & 2 \\
\hline 13 & International Journal of Mobile and Blended Learning & Journal & 2 \\
\hline 14 & Education Sciences & Journal & 2 \\
\hline 15 & Journal of Educational Computing Research & Journal & 2 \\
\hline 16 & Language Learning Journal & Journal & 2 \\
\hline 17 & Research in Learning Technology & Journal & 1 \\
\hline 18 & International Journal of Game-Based Learning & Journal & 1 \\
\hline 19 & Turkish Online Journal of Educational Technology & Journal & 1 \\
\hline 20 & British Journal of Educational Technology & Journal & 1 \\
\hline 21 & Interactive Technology and Smart Education & Journal & 1 \\
\hline 22 & Language Culture and Curriculum & Journal & 1 \\
\hline 23 & International Journal of Computer-Assisted Language Learning and Teaching & Journal & 1 \\
\hline 24 & Australian Educational Researcher & Journal & 1 \\
\hline 25 & Journal of Information Technology Education-Research & Journal & 1 \\
\hline 26 & International Journal of Emerging Technologies in Learning & Journal & 1 \\
\hline 27 & International Journal of Distance Education Technologies & Journal & 1 \\
\hline 28 & Journal of Computers in Education & Journal & 1 \\
\hline 29 & International Journal of Bilingual Education and Bilingualism & Journal & 1 \\
\hline 30 & International Journal of Instruction & Journal & 1 \\
\hline 31 & Journal of Language and Education & Journal & 1 \\
\hline 32 & MIER-Journal of Educational Studies Trends and Practices & Journal & 1 \\
\hline 33 & $\begin{array}{l}\text { International Journal of Information and Communication Technology } \\
\text { Education }\end{array}$ & Journal & 1 \\
\hline 34 & International Journal of Continuing Engineering Education and Life-Long & Journal & 1 \\
\hline
\end{tabular}




\begin{tabular}{|c|l|c|c|}
\hline & Learning & & \\
\hline 35 & 2019 International Conference on Innovative Computing (ICIC) & Conference & 1 \\
\hline 36 & $\begin{array}{l}\text { 2019 International Conference on Computer and Information Sciences } \\
\text { (ICCIS) }\end{array}$ & Conference & 1 \\
\hline 2019 12th International Conference on Information \& Communication \\
Technology and System (ICTS) & $\begin{array}{l}\text { Conference } \\
\text { Technologies (ICCTCT) }\end{array}$ & 1 \\
\hline 39 & $\begin{array}{l}\text { 2020 IEEE 20th International Conference on Advanced Learning } \\
\text { Technologies (ICALT) }\end{array}$ & Conference & 1 \\
\hline
\end{tabular}




\section{Table 9 (on next page)}

Quality Assessment 
Table 9. Quality Assessment

\begin{tabular}{|c|c|c|c|c|c|c|c|c|c|c|}
\hline \multirow[b]{2}{*}{ Ref. } & \multicolumn{5}{|c|}{ Classification } & \multicolumn{5}{|c|}{ Quality Assessment } \\
\hline & P. Channel & $\begin{array}{l}\text { Publication } \\
\text { Year }\end{array}$ & Research Type & $\begin{array}{c}\text { Empirical } \\
\text { Type / Method }\end{array}$ & Methodology & (a) & (b) & (c) & (d) & Score \\
\hline$[1]$ & $\begin{array}{c}\text { Research } \\
\text { Journal }\end{array}$ & 2012 & $\begin{array}{l}\text { Evaluation } \\
\text { Framework }\end{array}$ & No & $\begin{array}{l}\text { Formulation of conceptual } \\
\text { model }\end{array}$ & 1 & 0 & 0 & 4 & 5 \\
\hline$[2]$ & $\begin{array}{c}\text { Research } \\
\text { Journal }\end{array}$ & 2012 & $\begin{array}{l}\text { Evaluation } \\
\text { Framework }\end{array}$ & No & $\begin{array}{c}\text { Formulation of } \\
\text { Pedagogical Framework }\end{array}$ & 1 & 0 & 0 & 3 & 4 \\
\hline [3] & $\begin{array}{c}\text { Research } \\
\text { Journal }\end{array}$ & 2013 & Evaluation Research & Survey & Statistical Analysis & 1 & 2 & 1 & 4 & 8 \\
\hline$[4]$ & $\begin{array}{c}\text { Research } \\
\text { Journal }\end{array}$ & 2010 & Evaluation Research & Survey & Questionnaire & 1 & 2 & 1 & 4 & 8 \\
\hline$[5]$ & $\begin{array}{c}\text { Research } \\
\text { Journal }\end{array}$ & 2011 & Evaluation Research & Survey & Questionnaire & 1 & 2 & 1 & 4 & 8 \\
\hline$[6]$ & $\begin{array}{l}\text { Research } \\
\text { Journal }\end{array}$ & 2013 & Solution Proposal & Experiment & $\begin{array}{c}\text { Personalized } \\
\text { recommendation-based } \\
\text { approach }\end{array}$ & 1 & 2 & 1 & 4 & 8 \\
\hline$[7]$ & $\begin{array}{c}\text { Research } \\
\text { Journal }\end{array}$ & 2010 & Evaluation Research & Survey & Questionnaire & 1 & 2 & 1 & 4 & 8 \\
\hline [8] & $\begin{array}{c}\text { Research } \\
\text { Journal }\end{array}$ & 2011 & Evaluation Research & Survey & Interview and Observation & 1 & 1 & 1 & 3 & 6 \\
\hline [9] & $\begin{array}{c}\text { Research } \\
\text { Journal }\end{array}$ & 2011 & Evaluation Research & Experiment & Statistical Analysis & 1 & 1 & 1 & 1 & 4 \\
\hline$[10]$ & $\begin{array}{c}\text { Research } \\
\text { Journal }\end{array}$ & 2014 & Solution Proposal & Experiment & Game & 1 & 2 & 1 & 4 & 8 \\
\hline [11] & $\begin{array}{c}\text { Research } \\
\text { Journal }\end{array}$ & 2016 & Evaluation Research & $\begin{array}{c}\text { Experiment }+ \\
\text { Survey } \\
\end{array}$ & $\begin{array}{c}\text { Learning tool and } \\
\text { Questionnaire }\end{array}$ & 1 & 2 & 1 & 4 & 8 \\
\hline$[12]$ & $\begin{array}{c}\text { Research } \\
\text { Journal }\end{array}$ & 2014 & Solution Proposal & $\begin{array}{c}\text { Experiment }+ \\
\text { Survey }\end{array}$ & $\begin{array}{l}\text { Reading tool and } \\
\text { Questionnaire }\end{array}$ & 1 & 2 & 1 & 4 & 8 \\
\hline [13] & $\begin{array}{c}\text { Research } \\
\text { Journal }\end{array}$ & 2012 & Evaluation Research & Survey & Questionnaire & 1 & 2 & 1 & 4 & 8 \\
\hline [14] & $\begin{array}{c}\text { Research } \\
\text { Journal }\end{array}$ & 2016 & Evaluation Research & Survey & $\begin{array}{c}\text { Questionnaire, Semi- } \\
\text { Structured Interview and } \\
\text { Observation }\end{array}$ & 1 & 2 & 1 & 4 & 8 \\
\hline$[15]$ & $\begin{array}{c}\text { Research } \\
\text { Journal }\end{array}$ & 2015 & Evaluation Research & $\begin{array}{l}\text { Experiment } \\
\text { and Survey }\end{array}$ & Photo taking & 1 & 1 & 1 & 4 & 7 \\
\hline [16] & $\begin{array}{c}\text { Research } \\
\text { Journal }\end{array}$ & 2015 & Solution Proposal & Experiment & Instructional tool & 1 & 1 & 1 & 4 & 7 \\
\hline [17] & $\begin{array}{c}\text { Research } \\
\text { Journal }\end{array}$ & 2014 & Solution Proposal & Framework 0 & Framework proposed & 1 & 0 & 0 & 4 & 5 \\
\hline$[18]$ & $\begin{array}{c}\text { Research } \\
\text { Journal }\end{array}$ & 2013 & Evaluation Research & Survey & Questionnaire & 1 & 2 & 1 & 4 & 8 \\
\hline [19] & $\begin{array}{c}\text { Research } \\
\text { Journal }\end{array}$ & 2016 & Solution Proposal & Model 0 & Model Proposed & 1 & 0 & 0 & 3 & 4 \\
\hline [20] & $\begin{array}{c}\text { Research } \\
\text { Journal }\end{array}$ & 2018 & Solution Proposal & Model & Game (Vocabulary) & 1 & 2 & 0 & 4 & 7 \\
\hline [21] & $\begin{array}{c}\text { Research } \\
\text { Journal }\end{array}$ & 2014 & Evaluation Research & Survey & Questionnaire & 1 & 2 & 1 & 4 & 8 \\
\hline [22] & $\begin{array}{c}\text { Research } \\
\text { Journal }\end{array}$ & 2018 & Evaluation Research & Survey & $\begin{array}{c}\text { Online Survey and } \\
\text { Interview }\end{array}$ & 1 & 2 & 1 & 4 & 8 \\
\hline [23] & $\begin{array}{c}\text { Research } \\
\text { Journal }\end{array}$ & 2017 & Evaluation Research & Survey & $\begin{array}{l}\text { Interview and Focus group } \\
\text { discussion }\end{array}$ & 1 & 2 & 1 & 0 & 4 \\
\hline [24] & $\begin{array}{c}\text { Research } \\
\text { Journal }\end{array}$ & 2013 & Solution Proposal & Experiment & Model Used & 1 & 2 & 1 & 4 & 8 \\
\hline$[25]$ & $\begin{array}{c}\text { Research } \\
\text { Journal }\end{array}$ & 2012 & Evaluation Research & $\begin{array}{c}\text { Statistical } \\
\text { Analysis } \\
\end{array}$ & Assessment Test & 1 & 2 & 1 & 3 & 7 \\
\hline [26] & $\begin{array}{c}\text { Research } \\
\text { Journal }\end{array}$ & 2014 & Solution Proposal & $\begin{array}{c}\text { Experiment }+ \\
\text { Survey }\end{array}$ & $\begin{array}{l}\text { Game, Questionnaire and } \\
\text { Interview }\end{array}$ & 1 & 2 & 1 & 4 & 8 \\
\hline
\end{tabular}




\begin{tabular}{|c|c|c|c|c|c|c|c|c|c|c|}
\hline [27] & $\begin{array}{c}\text { Research } \\
\text { Journal }\end{array}$ & 2013 & Solution Proposal & No & Informal & 1 & 1 & 0 & 2 & 4 \\
\hline [28] & $\begin{array}{c}\text { Research } \\
\text { Journal }\end{array}$ & 2017 & Solution Proposal & Experiment & Game & 1 & 2 & 1 & 4 & 8 \\
\hline [29] & $\begin{array}{c}\text { Research } \\
\text { Journal }\end{array}$ & 2017 & Evaluation Research & Survey & Questionnaire & 1 & 2 & 1 & 2 & 6 \\
\hline [30] & $\begin{array}{c}\text { Research } \\
\text { Journal }\end{array}$ & 2014 & Evaluation Research & Survey & Interviews & 1 & 2 & 1 & 2 & 6 \\
\hline [31] & $\begin{array}{c}\text { Research } \\
\text { Journal }\end{array}$ & 2019 & Solution Proposal & Experiment & Captioned Video & 1 & 2 & 1 & 4 & 8 \\
\hline [32] & $\begin{array}{c}\text { Research } \\
\text { Journal }\end{array}$ & 2019 & Evaluation Research & Survey & $\begin{array}{l}\text { Questionnaire and } \\
\text { Interviews }\end{array}$ & 1 & 2 & 1 & 4 & 8 \\
\hline [33] & $\begin{array}{c}\text { Research } \\
\text { Journal }\end{array}$ & 2018 & Evaluation Research & Survey & Questionnaire & 1 & 2 & 1 & 2 & 6 \\
\hline [34] & $\begin{array}{c}\text { Research } \\
\text { Journal }\end{array}$ & 2017 & Evaluation Research & Survey & Questionnaire & 1 & 2 & 1 & 3 & 7 \\
\hline [35] & $\begin{array}{c}\text { Research } \\
\text { Journal }\end{array}$ & 2016 & Evaluation Research & Survey & Questionnaire & 1 & 2 & 1 & 2 & 6 \\
\hline [36] & $\begin{array}{c}\text { Research } \\
\text { Journal }\end{array}$ & 2012 & Evaluation Research & Survey & Test and Interviews & 1 & 2 & 1 & 2 & 6 \\
\hline [37] & $\begin{array}{c}\text { Research } \\
\text { Journal }\end{array}$ & 2018 & Evaluation Research & No & Review & 1 & 1 & 0 & 4 & 6 \\
\hline [38] & $\begin{array}{c}\text { Research } \\
\text { Journal }\end{array}$ & 2018 & Evaluation Research & $\begin{array}{l}\text { Experiment }+ \\
\text { Survey }\end{array}$ & Statistical Analysis & 1 & 2 & 1 & 4 & 8 \\
\hline [39] & $\begin{array}{c}\text { Research } \\
\text { Journal }\end{array}$ & 2017 & Evaluation Research & Survey & $\begin{array}{c}\text { Questionnaire and Class } \\
\text { Observation }\end{array}$ & 1 & 2 & 1 & 2 & 6 \\
\hline [40] & $\begin{array}{c}\text { Research } \\
\text { Journal }\end{array}$ & 2017 & Evaluation Research & $\begin{array}{c}\text { Survey }+ \\
\text { Experiment }\end{array}$ & $\begin{array}{c}\text { Questionnaire and Log } \\
\text { Analyzer }\end{array}$ & 1 & 2 & 1 & 4 & 8 \\
\hline [41] & $\begin{array}{c}\text { Research } \\
\text { Journal }\end{array}$ & 2016 & Solution Proposal & $\begin{array}{c}\text { Experiment }+ \\
\text { Survey }\end{array}$ & $\begin{array}{c}\text { Tool for academic test and } \\
\text { Questionnaire with } \\
\text { Interviews }\end{array}$ & 1 & 2 & 1 & 0 & 4 \\
\hline [42] & $\begin{array}{c}\text { Research } \\
\text { Journal }\end{array}$ & 2016 & Review & No & Informal & 1 & 1 & 0 & 4 & 6 \\
\hline [43] & $\begin{array}{c}\text { Research } \\
\text { Journal }\end{array}$ & 2018 & Evaluation Research & Survey & Questionnaire & 1 & 2 & 1 & 2 & 6 \\
\hline [44] & $\begin{array}{c}\text { Research } \\
\text { Journal }\end{array}$ & 2018 & Evaluation Research & Survey & Questionnaire & 1 & 2 & 1 & 3 & 7 \\
\hline [45] & $\begin{array}{c}\text { Research } \\
\text { Journal }\end{array}$ & 2018 & Evaluation Research & Survey & Interview & 1 & 2 & 1 & 1 & 5 \\
\hline [46] & $\begin{array}{c}\text { Research } \\
\text { Journal }\end{array}$ & 2019 & Evaluation Research & Survey & Questionnaire & 1 & 2 & 1 & 2 & 6 \\
\hline [47] & $\begin{array}{c}\text { Research } \\
\text { Journal }\end{array}$ & 2019 & Evaluation Research & Survey & $\begin{array}{l}\text { Questionnaire and } \\
\text { Interviews }\end{array}$ & 1 & 2 & 1 & 4 & 8 \\
\hline [48] & $\begin{array}{c}\text { Research } \\
\text { Journal }\end{array}$ & 2019 & Evaluation Research & Experiment & Formal & 1 & 2 & 1 & 3 & 7 \\
\hline [49] & $\begin{array}{c}\text { Research } \\
\text { Journal }\end{array}$ & 2019 & Evaluation Research & Experiment & Formal & 1 & 2 & 1 & 3 & 7 \\
\hline [50] & $\begin{array}{c}\text { Research } \\
\text { Journal }\end{array}$ & 2018 & Evaluation Research & Survey & Interview & 1 & 2 & 1 & 0 & 4 \\
\hline [51] & $\begin{array}{c}\text { Research } \\
\text { Journal }\end{array}$ & 2017 & Evaluation Research & Experiment & Statistical Analysis & 1 & 2 & 1 & 0 & 4 \\
\hline [52] & $\begin{array}{c}\text { Research } \\
\text { Journal }\end{array}$ & 2013 & Solution Proposal & Experiment & Game & 1 & 2 & 1 & 4 & 8 \\
\hline [53] & $\begin{array}{c}\text { Research } \\
\text { Journal }\end{array}$ & 2020 & Evaluation Research & Experiment & Statistical Analysis & 1 & 2 & 1 & 4 & 8 \\
\hline [54] & $\begin{array}{c}\text { Research } \\
\text { Journal }\end{array}$ & 2020 & Solution Proposal & Experiment & Learning tool for English & 1 & 1 & 1 & 2 & 5 \\
\hline [55] & $\begin{array}{c}\text { Research } \\
\text { Journal }\end{array}$ & 2020 & Evaluation Research & Survey & Questionnaire & 1 & 2 & 1 & 2 & 6 \\
\hline
\end{tabular}




\begin{tabular}{|c|c|c|c|c|c|c|c|c|c|c|}
\hline [56] & $\begin{array}{c}\text { Research } \\
\text { Journal }\end{array}$ & 2019 & Solution Proposal & Experiment & Game (Tenses) & 1 & 2 & 1 & 4 & 8 \\
\hline$[57]$ & $\begin{array}{c}\text { Research } \\
\text { Journal }\end{array}$ & 2019 & Evaluation Research & Survey & $\begin{array}{c}\text { Questionnaire and } \\
\text { Interviews }\end{array}$ & 1 & 2 & 1 & 4 & 8 \\
\hline$[58]$ & $\begin{array}{c}\text { Research } \\
\text { Journal }\end{array}$ & 2019 & Evaluation Research & Survey & Questionnaire & 1 & 2 & 1 & 4 & 8 \\
\hline [59] & $\begin{array}{c}\text { Research } \\
\text { Journal }\end{array}$ & 2012 & Evaluation Research & Survey & $\begin{array}{l}\text { Questionnaire, Interviews } \\
\text { and Log files }\end{array}$ & 1 & 2 & 1 & 1 & 5 \\
\hline$[60]$ & $\begin{array}{c}\text { Research } \\
\text { Journal }\end{array}$ & 2020 & Evaluation Research & Survey & Questionnaire & 1 & 2 & 1 & 1 & 5 \\
\hline [61] & $\begin{array}{c}\text { Research } \\
\text { Journal }\end{array}$ & 2020 & Evaluation Research & Survey & $\begin{array}{c}\text { Questionnaire and } \\
\text { Interviews }\end{array}$ & 1 & 2 & 1 & 1 & 5 \\
\hline$[62]$ & Conference & 2019 & Evaluation Research & Survey & Questionnaire & 1 & 2 & 1 & 0 & 4 \\
\hline [63] & $\begin{array}{c}\text { Research } \\
\text { Journal }\end{array}$ & 2020 & Evaluation Research & Survey & $\begin{array}{c}\text { Questionnaire and } \\
\text { Interviews }\end{array}$ & 1 & 2 & 1 & 1 & 5 \\
\hline [111] & Conference & 2019 & Evaluation Research & Experiment & SWOT Analysis & 1 & 2 & 1 & 1 & 5 \\
\hline$[112]$ & Conference & 2019 & Evaluation Research & Survey & Questionnaire & 1 & 1 & 1 & 2 & 5 \\
\hline [113] & Conference & 2018 & Evaluation Research & Experiment & Interview & 1 & 2 & 1 & 2 & 6 \\
\hline [114] & Conference & 2020 & Evaluation Research & Survey & Questionnaire & 1 & 1 & 1 & 3 & 6 \\
\hline
\end{tabular}

2 


\title{
Table $\mathbf{1 0}$ (on next page)
}

\author{
Quality Assessment Score
}


1 Table 10. Quality Assessment Score

\begin{tabular}{|c|c|c|}
\hline References & Score & Total \\
\hline $\begin{array}{l}{[3][4][5][6][7][10][11][12][13][14][18][21][22][24][26]} \\
{[28][31][32][38][40][47][52][53][56][57][58]}\end{array}$ & 8 & 26 \\
\hline [15] [16] [20] [25] [34] [44] [48] [49] & 7 & 8 \\
\hline$[8][29][30][33][35][36][37][39][42][43][46][55][113][114]$ & 6 & 14 \\
\hline [1] [17] [45] [54] [59] [60] [61] [63] [111] [112] & 5 & 10 \\
\hline [2] [9] [19] [23] [27] [41] [50] [51] [62] & 4 & 9 \\
\hline
\end{tabular}

2 


\section{Table 11 (on next page)}

Theory, Framework and Model used in the studies 
Table.11 Theory, Framework and Model used in the studies

\begin{tabular}{|c|c|c|c|c|c|}
\hline Ref. & Year & Application & Theory & Model/Framework & Description \\
\hline [1] & 2012 & $\begin{array}{l}\text { Learning } \\
\text { readiness }\end{array}$ & $\begin{array}{l}\text { Theory of Planned } \\
\text { Behavior (TPB) }\end{array}$ & $\begin{array}{l}\text { Conceptual model, } \\
\text { based on the Theory } \\
\text { of Planned } \\
\text { Behavior (TPB) }\end{array}$ & $\begin{array}{l}\text { A conceptual model based on the } \\
\text { Theory of Planned Behavior (TPB) } \\
\text { explained how young adults' } \\
\text { behavior affects their intention. }\end{array}$ \\
\hline [2] & 2012 & Pedagogy & $\begin{array}{l}\text { Iterative revision by } \\
\text { stakeholders }\end{array}$ & $\begin{array}{l}\text { Pedagogical } \\
\text { Framework }\end{array}$ & $\begin{array}{l}\text { The Framework used to criticize } \\
\text { pedagogy, allowing the comparison } \\
\text { of mobile practices and pedagogical } \\
\text { methods. }\end{array}$ \\
\hline$[3]$ & 2013 & $\begin{array}{l}\text { Achievement } \\
\text { and Attitude }\end{array}$ & Dual-coding Theory & $\begin{array}{l}\text { 'Here and now' } \\
\text { mobile learning } \\
\text { framework }\end{array}$ & $\begin{array}{l}\text { A three characteristics (Engaging, } \\
\text { Authentic, and Informal) } \\
\text { Framework was create to study } \\
\text { mobile learning's effect on the } \\
\text { learning environment. }\end{array}$ \\
\hline [4] & 2010 & $\begin{array}{l}\text { Usefulness } \\
\text { and Personal } \\
\text { Innovativeness }\end{array}$ & $\begin{array}{l}\text { Theory of reasoned } \\
\text { action }\end{array}$ & $\begin{array}{l}\text { A hypothesized } \\
\text { model of m- } \\
\text { learning adoption }\end{array}$ & $\begin{array}{l}\text { A hypothesized model of m-learning } \\
\text { is proposed based on the } \\
\text { Technology Acceptance Model } \\
\text { (TAM). }\end{array}$ \\
\hline$[5]$ & 2011 & Learning & Learning Theory & $\begin{array}{l}\text { Pedagogical } \\
\text { Framework }\end{array}$ & $\begin{array}{l}\text { A pedagogical framework is } \\
\text { adopted and used for mobile English } \\
\text { learning for fifth-grade students. }\end{array}$ \\
\hline [6] & 2013 & Reading & Not Available & TAM & $\begin{array}{l}\text { A personalized recommendation } \\
\text { based mobile language learning } \\
\text { approach was proposed. }\end{array}$ \\
\hline [7] & 2010 & Vocabulary & Not Available & MALL framework & $\begin{array}{l}\text { Two case studies were presented } \\
\text { based on MALL framework. }\end{array}$ \\
\hline [8] & 2011 & $\begin{array}{l}\text { Spanish } \\
\text { language } \\
\text { learning }\end{array}$ & Not Available & Not Available & $\begin{array}{l}\text { A mobile game for learning Spanish } \\
\text { was developed. }\end{array}$ \\
\hline [9] & 2011 & Vocabulary & Learners' active role & $\begin{array}{l}\text { Channell's } \\
\text { conceptual } \\
\text { Framework }\end{array}$ & $\begin{array}{l}\text { Reexamined the effectiveness of } \\
\text { vocabulary learning using mobile } \\
\text { phones, Channell's Conceptual } \\
\text { Framework was used. }\end{array}$ \\
\hline [10] & 2014 & Vocabulary & Not Available & Tutoring model & $\begin{array}{l}\text { Mobile English learning application } \\
\text { developed and used for vocabulary } \\
\text { learning. }\end{array}$ \\
\hline [11] & 2016 & Vocabulary & Motivation theory & ARCS model & $\begin{array}{l}\text { A strategy for vocabulary learning } \\
\text { on the basis of the ARCS model and } \\
\text { motivation theory was developed. }\end{array}$ \\
\hline [12] & 2014 & Reading & $\begin{array}{l}\text { Multimedia learning } \\
\text { theory }\end{array}$ & TAM & $\begin{array}{l}\text { The purpose was to investigate the } \\
\text { effect of using mobile tablet PCs for } \\
\text { adolescent English learners. }\end{array}$ \\
\hline [13] & 2012 & $\begin{array}{l}\text { English } \\
\text { language } \\
\text { learning }\end{array}$ & $\begin{array}{l}\text { Self-determination } \\
\text { theory }\end{array}$ & $\begin{array}{l}\text { Mobile English } \\
\text { learning outcome } \\
\text { (MELO) } \\
\text { framework }\end{array}$ & $\begin{array}{l}\text { The M-COPE framework allowed } \\
\text { teachers to understand five main } \\
\text { aspects of mobile learning: Mobile } \\
\text { affordance, Ethics, Pedagogy, and } \\
\text { Outcomes. }\end{array}$ \\
\hline [14] & 2016 & $\begin{array}{l}\text { English } \\
\text { language } \\
\text { learning }\end{array}$ & Not Available & Not Available & $\begin{array}{l}\text { The aim was to see mobile devices } \\
\text { for English as a foreign language } \\
\text { among Iranian students. }\end{array}$ \\
\hline [15] & 2015 & $\begin{array}{l}\text { English } \\
\text { language } \\
\text { learning }\end{array}$ & Sociocultural theory & Not Available & $\begin{array}{l}\text { The study investigated the impact of } \\
\text { photo-taking through mobiles for } \\
\text { English phrase learning. }\end{array}$ \\
\hline [16] & 2015 & Pronunciation & Not Available & Not Available & The study investigated the \\
\hline
\end{tabular}




\begin{tabular}{|c|c|c|c|c|c|}
\hline & & of French & & & $\begin{array}{l}\text { acquisition of French vowels using a } \\
\text { mobile learning environment. }\end{array}$ \\
\hline [17] & 2014 & Pedagogy & $\begin{array}{l}\text { Instructional design } \\
\text { theory }\end{array}$ & M-COPE & $\begin{array}{l}\text { The M-COPE framework allowed } \\
\text { teachers to understand five main } \\
\text { aspects of mobile learning: Mobile } \\
\text { affordance, Ethics, Pedagogy, and } \\
\text { Outcomes. }\end{array}$ \\
\hline [18] & 2013 & Idioms & Not Available & Chans' Framework & $\begin{array}{l}\text { The study presented a MALL design } \\
\text { that highlighted students' habits and } \\
\text { skills for making meanings from } \\
\text { routine event pictures. }\end{array}$ \\
\hline [19] & 2016 & $\begin{array}{l}\text { English } \\
\text { language } \\
\text { learning }\end{array}$ & Not Available & $\begin{array}{l}\text { Extended } \\
\text { Technology } \\
\text { Acceptance Model } \\
\text { developed }\end{array}$ & $\begin{array}{l}\text { The concept of the computational } \\
\text { model and their proposed } \\
\text { connections resulting from the use } \\
\text { of Davis's (1989) TAM was } \\
\text { introduced in this article. }\end{array}$ \\
\hline$[20]$ & 2018 & Vocabulary & $\begin{array}{l}\text { Motivation and } \\
\text { combined theory }\end{array}$ & ARCS Model & $\begin{array}{l}\text { A motivational model, ARCS } \\
\text { (Attention, Relevance, Confidence, } \\
\text { and Satisfaction), that considered } \\
\text { motivation to learners and } \\
\text { procedural assistance, was used in } \\
\text { this research. }\end{array}$ \\
\hline [21] & 2014 & $\begin{array}{l}\text { English } \\
\text { language } \\
\text { learning }\end{array}$ & $\begin{array}{l}\text { Self-determination } \\
\text { theory }\end{array}$ & $\begin{array}{l}\text { Mobile English } \\
\text { learning } \\
\text { continuance } \\
\text { intention (MELCI) } \\
\text { Framework }\end{array}$ & $\begin{array}{l}\text { MELCI framework was used in } \\
\text { which components of TAM (Davis, } \\
\text { 1989) were adopted to see the } \\
\text { influence of mobile English learning } \\
\text { satisfaction with self-management } \\
\text { of learning. }\end{array}$ \\
\hline$[22]$ & 2018 & $\begin{array}{l}\text { English } \\
\text { language } \\
\text { learning }\end{array}$ & Not Available & Kearneys' model & $\begin{array}{l}\text { The purpose of the study was to } \\
\text { explore the use of mobile learning } \\
\text { experiences across space and time. }\end{array}$ \\
\hline [23] & 2017 & $\begin{array}{l}\text { English } \\
\text { language } \\
\text { learning }\end{array}$ & Not Available & $\begin{array}{l}\text { Mobile-Blended } \\
\text { Collaborative } \\
\text { Learning model }\end{array}$ & $\begin{array}{l}\text { An instant messaging application } \\
\text { 'Whatsapp' was used to explore the } \\
\text { language proficiency. }\end{array}$ \\
\hline [24] & 2013 & $\begin{array}{l}\text { English } \\
\text { language } \\
\text { learning }\end{array}$ & $\begin{array}{l}\text { Theory of reasoned } \\
\text { action }\end{array}$ & TAM & $\begin{array}{l}\text { This study adopted the TAM by } \\
\text { incorporating perceived } \\
\text { convenience and curiosity factor for } \\
\text { mobile learning. }\end{array}$ \\
\hline$[25]$ & 2012 & $\begin{array}{l}\text { Vocabulary, } \\
\text { Grammar }\end{array}$ & Not Available & Not Available & $\begin{array}{l}\text { The study explored the effect of } \\
\text { integrated form-focused instruction } \\
\text { on learners' vocabulary, grammar, } \\
\text { and writing. }\end{array}$ \\
\hline [26] & 2014 & Idioms & Not Available & Not Available & $\begin{array}{l}\text { This research described the use of } \\
\text { mobile applications for idiomatic } \\
\text { expressions among language } \\
\text { learners. }\end{array}$ \\
\hline [27] & 2013 & $\begin{array}{l}\text { English } \\
\text { language } \\
\text { learning }\end{array}$ & $\begin{array}{c}\text { Multiple } \\
\text { Intelligence theory }\end{array}$ & Not Available & $\begin{array}{l}\text { The ideas of mobility and creativity } \\
\text { using LingoBee explored to support } \\
\text { language learners. }\end{array}$ \\
\hline [28] & 2017 & $\begin{array}{l}\text { English } \\
\text { language } \\
\text { learning }\end{array}$ & $\begin{array}{l}\text { Experiential } \\
\text { learning theory }\end{array}$ & $\begin{array}{l}\text { Experiential } \\
\text { learning theory used } \\
\text { as a learning model }\end{array}$ & $\begin{array}{l}\text { The experiential learning theory was } \\
\text { used as a learning model because } \\
\text { players seek knowledge by doing } \\
\text { activities in the game environment. }\end{array}$ \\
\hline [29] & 2017 & $\begin{array}{c}\text { English } \\
\text { language }\end{array}$ & Theory of diffusion & Not Available & $\begin{array}{l}\text { The purpose of the study was to } \\
\text { investigate the assistance of learning }\end{array}$ \\
\hline
\end{tabular}




\begin{tabular}{|c|c|c|c|c|c|}
\hline & & learning & & & $\begin{array}{l}\text { through mobile technology from } \\
\text { students. }\end{array}$ \\
\hline [30] & 2014 & Vocabulary & $\begin{array}{l}\text { Autonomous } \\
\text { learning theory }\end{array}$ & Not Available & $\begin{array}{l}\text { This research trialed the use of } \\
\text { mobile learning lexical spreadsheets } \\
\text { for new vocabulary reference and } \\
\text { consolidation. }\end{array}$ \\
\hline [31] & 2019 & Vocabulary & Dual-coding theory & $\begin{array}{l}\text { Working memory } \\
\text { model and } \\
\text { Multimedia } \\
\text { principle }\end{array}$ & $\begin{array}{l}\text { Dual-coding theory, working } \\
\text { memory model, and Multimedia } \\
\text { principle used in the study to } \\
\text { investigate the effects of the } \\
\text { captioning condition. }\end{array}$ \\
\hline [32] & 2019 & $\begin{array}{l}\text { English } \\
\text { language } \\
\text { learning }\end{array}$ & Not Available & $\begin{array}{l}\text { Self-regulated } \\
\text { learning framework } \\
\text { by Garrison }\end{array}$ & $\begin{array}{l}\text { Self-directed learning, Garrison's } \\
\text { comprehensive theoretical approach } \\
\text { (1997) was used in this research. }\end{array}$ \\
\hline [33] & 2018 & $\begin{array}{l}\text { English } \\
\text { language } \\
\text { learning }\end{array}$ & Not Available & Not Available & $\begin{array}{l}\text { The study investigated the higher } \\
\text { education students' attitude towards } \\
\text { using the smartphone for language } \\
\text { learning. }\end{array}$ \\
\hline [34] & 2017 & $\begin{array}{l}\text { English } \\
\text { language } \\
\text { learning }\end{array}$ & Unified theory & $\begin{array}{l}\text { A unified theory of } \\
\text { acceptance and use } \\
\text { of technology }\end{array}$ & $\begin{array}{l}\text { The study explored the usage of } \\
\text { MALL applications impacts the } \\
\text { attitude of learning for language } \\
\text { learning. }\end{array}$ \\
\hline [35] & 2016 & $\begin{array}{l}\text { Oral English } \\
\text { learning }\end{array}$ & Not Available & Not Available & $\begin{array}{l}\text { An application } \\
\text { practicing English osigned for } \\
\text { users. }\end{array}$ \\
\hline [36] & 2012 & $\begin{array}{l}\text { English } \\
\text { language } \\
\text { learning }\end{array}$ & Not Available & Not Available & $\begin{array}{l}\text { The researcher made the } \\
\text { investigation of English as a foreign } \\
\text { language effect in this study of } \\
\text { Japan. }\end{array}$ \\
\hline [37] & 2018 & $\begin{array}{l}\text { English } \\
\text { language } \\
\text { learning }\end{array}$ & Not Available & Not Available & $\begin{array}{l}\text { A mobile-based application, } \\
\text { 'English Practice' was used to } \\
\text { analyze active users' behavior from } \\
\text { different countries. }\end{array}$ \\
\hline [38] & 2018 & Vocabulary & $\begin{array}{l}\text { A generative theory } \\
\text { of multimedia } \\
\text { learning }\end{array}$ & Not Available & $\begin{array}{l}\text { The effect of multimedia glosses on } \\
\text { vocabulary learning was } \\
\text { investigated in this study. }\end{array}$ \\
\hline [39] & 2017 & $\begin{array}{l}\text { English for a } \\
\text { specific } \\
\text { purpose }\end{array}$ & Audiolingual theory & $\begin{array}{l}\text { A framework for } \\
\text { LINE application }\end{array}$ & $\begin{array}{l}\text { For business language testing } \\
\text { service (BULATS), a framework } \\
\text { based on components were adopted: } \\
\text { Teaching Method, Learning } \\
\text { Satisfaction, } \\
\begin{array}{l}\text { Effectiveness, and Qualitative } \\
\text { analysis }\end{array}\end{array}$ \\
\hline [40] & 2017 & Vocabulary & $\begin{array}{l}\text { Theory of cognitive } \\
\text { style }\end{array}$ & $\begin{array}{l}\text { Mobile } \\
\text { framework }\end{array}$ & $\begin{array}{l}\text { An offline mobile learning system } \\
\text { framework was developed, which } \\
\text { worked any time and without the } \\
\text { internet for vocabulary learning. }\end{array}$ \\
\hline [41] & 2016 & Vocabulary & Not Available & $\begin{array}{l}\text { Data drove learning } \\
\text { model }\end{array}$ & $\begin{array}{l}\text { A mobile application, 'mobile DDL,' } \\
\text { was designed and developed for } \\
\text { learning English. }\end{array}$ \\
\hline [42] & 2016 & Vocabulary & Not Available & Not Available & $\begin{array}{l}\text { This study focused on a group of } \\
\text { school children for English language } \\
\text { instruction in the fall term. }\end{array}$ \\
\hline [43] & 2018 & $\begin{array}{l}\text { English } \\
\text { language }\end{array}$ & Not Available & $\begin{array}{l}\text { A Pedagogical } \\
\text { framework }\end{array}$ & $\begin{array}{l}\text { Task-based language teaching } \\
\text { (TBLT) used as a pedagogical }\end{array}$ \\
\hline
\end{tabular}




\begin{tabular}{|c|c|c|c|c|c|}
\hline & & learning & & & framework \\
\hline [44] & 2018 & $\begin{array}{l}\text { English } \\
\text { language } \\
\text { learning }\end{array}$ & Attribution theory & $\begin{array}{l}\text { Theoretical } \\
\text { Framework of } \\
\text { attribution theory }\end{array}$ & $\begin{array}{l}\text { The study used Weiner's attribution } \\
\text { theory (1992) in the Framework that } \\
\text { provided failure or success reasons } \\
\text { or explanations for people in } \\
\text { education. }\end{array}$ \\
\hline [45] & 2018 & $\begin{array}{l}\text { English } \\
\text { language } \\
\text { learning }\end{array}$ & Not Available & Not Available & $\begin{array}{l}\text { WhatsApp and Google were used to } \\
\text { access reading material and to } \\
\text { interact with peers and instructors. }\end{array}$ \\
\hline [46] & 2019 & Vocabulary & $\begin{array}{l}\text { Cognitive theory of } \\
\text { multimedia learning }\end{array}$ & Not Available & $\begin{array}{l}\text { The study examined the effect of } \\
\text { enhancing undergraduate students' } \\
\text { knowledge retention of vocabulary. }\end{array}$ \\
\hline [47] & 2019 & Vocabulary & Not Available & Not Available & $\begin{array}{l}\text { An application' PHONE Words' } \\
\text { designed with game-related and } \\
\text { non-game related functions to } \\
\text { measure students' perception } \\
\text { performance. }\end{array}$ \\
\hline [48] & 2019 & $\begin{array}{l}\text { English } \\
\text { language } \\
\text { learning }\end{array}$ & Sociocultural theory & Not Available & $\begin{array}{l}\text { The study investigated autonomy for } \\
\text { language learning in primary } \\
\text { schools using the iTEO application. }\end{array}$ \\
\hline [49] & 2019 & Vocabulary & Not Available & Not Available & $\begin{array}{l}\text { The researchers experimented with } \\
\text { vocabulary teaching to young } \\
\text { children through drama. }\end{array}$ \\
\hline [50] & 2018 & Vocabulary & Not Available & Sarrab et. al model & $\begin{array}{l}\text { The aim was to design and develop } \\
\text { a mobile application to enhance } \\
\text { teaching and learning vocabulary. }\end{array}$ \\
\hline [51] & 2017 & Vocabulary & Not Available & Not Available & $\begin{array}{l}\text { The study examined the mobile } \\
\text { application efficiency on teaching } \\
\text { phrases. }\end{array}$ \\
\hline [52] & 2013 & Vocabulary & Instructional theory & $\begin{array}{l}\text { Theoretical } \\
\text { Framework }\end{array}$ & $\begin{array}{l}\text { The 'Word Score,' a serious game, } \\
\text { was developed based on Bom (2011) } \\
\text { by discussing the study's literature. }\end{array}$ \\
\hline [53] & 2020 & $\begin{array}{l}\text { English } \\
\text { language } \\
\text { learning }\end{array}$ & Not Available & $\begin{array}{l}\text { Module } \\
\text { Intervention Model }\end{array}$ & $\begin{array}{l}\text { The study investigated the } \\
\text { performance of learners using } \\
\text { mobile devices by examining a } \\
\text { guided learning approach. }\end{array}$ \\
\hline [54] & 2020 & $\begin{array}{l}\text { English } \\
\text { language } \\
\text { learning }\end{array}$ & Not Available & $\begin{array}{l}\text { M-Learning System } \\
\text { architecture }\end{array}$ & $\begin{array}{l}\text { An architectural model was } \\
\text { proposed in the study with three } \\
\text { components; the Domain model, the } \\
\text { Pedagogical model, and the learner } \\
\text { model. }\end{array}$ \\
\hline$[55]$ & 2020 & Vocabulary & Not Available & Not Available & $\begin{array}{l}\text { The perception of students was } \\
\text { discussed for the use of mobile } \\
\text { applications aimed at learning } \\
\text { vocabulary. }\end{array}$ \\
\hline [56] & 2019 & Tenses & Not Available & $\begin{array}{l}\text { The Framework of } \\
\text { mobile learning tool } \\
\text { acceptance }\end{array}$ & $\begin{array}{l}\text { The study aimed to determine the } \\
\text { effectiveness of the SOS mobile } \\
\text { game to teach tenses in English. }\end{array}$ \\
\hline [57] & 2019 & $\begin{array}{l}\text { English } \\
\text { language } \\
\text { learning }\end{array}$ & $\begin{array}{l}\text { Second language } \\
\text { acquisition theory }\end{array}$ & A theoretical model & $\begin{array}{l}\text { By discussing two frameworks: 1) } \\
\text { Framework for the rational analysis } \\
\text { of mobile education (FRAME), and } \\
\text { 2) TAM and TAM } 2 \text { model that } \\
\text { focused on technology } \\
\text { enhancement. }\end{array}$ \\
\hline [58] & 2019 & Grammar & Not Available & Not Available & This study developed a mobile \\
\hline
\end{tabular}




\begin{tabular}{|c|c|c|c|c|c|}
\hline & & & & & $\begin{array}{l}\text { gaming approach using grammar } \\
\text { concept mapping for English. }\end{array}$ \\
\hline [59] & 2012 & Grammar & Not Available & $\begin{array}{l}\text { The affordance } \\
\text { framework }\end{array}$ & $\begin{array}{l}\text { The affordance framework, which } \\
\text { consisted of pedagogical, social, and } \\
\text { technological components, was used } \\
\text { to examine the ICT tools affordance } \\
\text { for language learning. }\end{array}$ \\
\hline [60] & 2020 & Usability & Not Available & Not Available & $\begin{array}{l}\text { The usability was measure through a } \\
\text { questionnaire survey for a mobile } \\
\text { application. }\end{array}$ \\
\hline [61] & 2020 & Usefulness & Not Available & TAM & $\begin{array}{l}\text { A survey was conducted based on } \\
\text { the TAM model to see the } \\
\text { usefulness of mobile applications. }\end{array}$ \\
\hline$[62]$ & 2019 & Effectiveness & Not Available & TAM & $\begin{array}{l}\text { To measure the effectiveness of } \\
\text { mobile application a survey was } \\
\text { conducted from teachers and } \\
\text { students. }\end{array}$ \\
\hline [63] & 2020 & $\begin{array}{l}\text { Usability and } \\
\text { Language } \\
\text { Learning }\end{array}$ & Not Available & Not Available & $\begin{array}{l}\text { An evaluation is conducted through } \\
\text { questionnaires and interviews to } \\
\text { measure the usability and design } \\
\text { issues of a mobile application. }\end{array}$ \\
\hline [111] & 2019 & $\begin{array}{l}\text { English } \\
\text { language } \\
\text { learning }\end{array}$ & Not Available & Not Available & $\begin{array}{l}\text { A taxonomy of challenges and } \\
\text { opportunities produced by games for } \\
\text { English language learning was } \\
\text { provided. }\end{array}$ \\
\hline [112] & 2019 & $\begin{array}{l}\text { English } \\
\text { language } \\
\text { learning }\end{array}$ & Not Available & $\begin{array}{l}\text { Mechanics, } \\
\text { Dynamics, and } \\
\text { Aesthetics } \\
\text { framework (MDA) }\end{array}$ & $\begin{array}{l}\text { The aim of this study to enhance } \\
\text { motivation and outcomes for } \\
\text { English language learning using } \\
\text { MDA framework. }\end{array}$ \\
\hline [113] & 2018 & $\begin{array}{l}\text { Learning } \\
\text { Spelling }\end{array}$ & Not Available & Not Available & $\begin{array}{l}\text { An application 'Dzongkha App' } \\
\text { developed for learning spelling for } \\
\text { kids. }\end{array}$ \\
\hline [114] & 2020 & $\begin{array}{l}\text { English } \\
\text { language } \\
\text { learning }\end{array}$ & $\begin{array}{c}\text { Behaviorist learning } \\
\text { theory }\end{array}$ & Not Available & $\begin{array}{l}\text { This study examined the perception } \\
\text { and support provided using mobile } \\
\text { technology from language learners. }\end{array}$ \\
\hline
\end{tabular}

2 


\section{Table 12 (on next page)}

Tools proposed by current studies 
Table 12. Tools proposed by current studies

\begin{tabular}{|c|c|c|c|c|c|c|}
\hline & Ref. & Year & $\begin{array}{l}\text { Application } \\
\text { Name }\end{array}$ & Description & $\begin{array}{l}\text { Application Evaluation } \\
\text { Method }\end{array}$ & Data Set \\
\hline \multirow{14}{*}{ 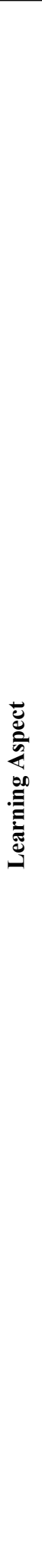 } & {$[6]$} & 2013 & $\begin{array}{l}\text { Vocabulary and } \\
\text { Annotation }\end{array}$ & $\begin{array}{l}\text { A mobile adaptive language learning system provided to } \\
\text { pupils for the improvement of learning outcomes. }\end{array}$ & $\begin{array}{l}\text { An application developed } \\
\text { based on the Literature } \\
\text { Review }\end{array}$ & Not Available \\
\hline & [9] & 2011 & $\begin{array}{l}\text { 'Fetion' SMS } \\
\text { text message }\end{array}$ & $\begin{array}{l}\text { To explore the effectiveness of vocabulary learning } \\
\text { through mobile technology, 'Fetion' an SMS text message } \\
\text { application provided by the Chinese mobile. }\end{array}$ & Not Available & Not Available \\
\hline & [11] & 2016 & $\begin{array}{l}\text { Mobile } \\
\text { Learning Tool }\end{array}$ & $\begin{array}{l}\text { A mobile learning tool and five-step vocabulary learning } \\
\text { (FSVL) strategy were developed in a situational learning } \\
\text { environment to assess their effects on English as a } \\
\text { foreign language (EFL) performance and learning } \\
\text { motivation. }\end{array}$ & $\begin{array}{l}\text { Developed based on the } \\
\text { Literature Review }\end{array}$ & Not Available \\
\hline & [12] & 2014 & $\begin{array}{l}\text { Raz-kids } \\
\text { (Online reading } \\
\text { tool) }\end{array}$ & $\begin{array}{l}\text { Raz-Kids, a mobile learning application for an extensive } \\
\text { reading program developed by 'Learning A to } Z \text { ' was used } \\
\text { to enhance their essential reading ability. }\end{array}$ & $\begin{array}{l}\text { This application is } \\
\text { developed by Learning A } \\
\text { to } \mathrm{Z} \text { (www.learninga- } \\
\text { z.com) }\end{array}$ & Not Available \\
\hline & {$[16]$} & 2015 & $\begin{array}{l}\text { Automatic } \\
\text { Speech } \\
\text { Recognition } \\
\text { (ASR) }\end{array}$ & $\begin{array}{l}\text { Nuance Dragon Dictation application was designed to } \\
\text { finish weekly pronunciation activities with immediate } \\
\text { written visuals (Pictures) feedback provided by the } \\
\text { application without any human interaction. }\end{array}$ & $\begin{array}{l}\text { Five native French } \\
\text { speakers pronounced all } \\
\text { words and phrases to test } \\
\text { the accuracy of the } \\
\text { application. }\end{array}$ & Not Available \\
\hline & [19] & 2016 & CoLaLe app & $\begin{array}{l}\text { The location-based vocabulary learning activities } \\
\text { application for Thai and German users was proposed in } \\
\text { the study to motivate personalized learning. }\end{array}$ & $\begin{array}{l}\text { For evaluation of the } \\
\text { application, a Short video } \\
\text { was made that } \\
\text { demonstrated the key } \\
\text { features mentioned above } \\
\text { to evaluate it using an } \\
\text { online questionnaire. }\end{array}$ & Not Available \\
\hline & [24] & 2013 & Mebook & $\begin{array}{l}\text { Mebook, designed and developed by a Taiwanese } \\
\text { company, is a multimedia eBook system and can be } \\
\text { played in MP3. }\end{array}$ & Not Available & Not Available \\
\hline & {$[27]$} & 2013 & LingoBee & $\begin{array}{l}\text { A crowdsourced mobile-based application, 'LingoBee,' } \\
\text { which was open source and available freely, was } \\
\text { explored in this study for creativity and mobility in } \\
\text { language learning. }\end{array}$ & $\begin{array}{l}\text { Evaluated through user } \\
\text { studies in European } \\
\text { Countries. }\end{array}$ & Not Available \\
\hline & {$[32]$} & 2019 & Duolingo & $\begin{array}{l}\text { Duolingo, a free mobile assisted language learning tool } \\
\text { (vocabulary acquisition) available for web and mobile } \\
\text { (Android and iOS) versions to examine out of class } \\
\text { engagement informally. }\end{array}$ & $\begin{array}{l}\text { Free application for } \\
\text { Android and iOS }\end{array}$ & $\begin{array}{l}\text { Duolingo } \\
\text { dashboard }\end{array}$ \\
\hline & [34] & 2017 & Duolingo & $\begin{array}{l}\text { Duolingo, a free mobile assisted language learning tool } \\
\text { (vocabulary acquisition) available for web and mobile } \\
\text { (Android and iOS) versions to examine out of class } \\
\text { engagement informally. }\end{array}$ & $\begin{array}{l}\text { Free application for } \\
\text { Android and iOS }\end{array}$ & $\begin{array}{l}\text { Duolingo } \\
\text { dashboard }\end{array}$ \\
\hline & [37] & 2018 & $\begin{array}{l}\text { English } \\
\text { Practice }\end{array}$ & $\begin{array}{l}\text { The application 'English Practice' was used to analyze the } \\
\text { usage behavior of } 53,825 \text { users from } 12 \text { countries. }\end{array}$ & $\begin{array}{l}\text { Online evaluation } \\
\text { through the "Google } \\
\text { Firebase analytics tool." }\end{array}$ & $\begin{array}{l}\text { Logfile of } \\
\text { Google Firebase }\end{array}$ \\
\hline & [38] & 2018 & $\begin{array}{l}\text { Mobile-assisted } \\
\text { listening } \\
\text { application }\end{array}$ & $\begin{array}{l}\text { 'Mobile assisted listening application' was developed to } \\
\text { examine L2 multimedia glosses' effects in a mobile } \\
\text { learning environment for vocabulary and listening } \\
\text { comprehension. }\end{array}$ & Pilot study & $\begin{array}{l}\text { Free recall } \\
\text { method for } \\
\text { listening } \\
\text { comprehension }\end{array}$ \\
\hline & {$[40]$} & 2017 & $\begin{array}{l}\text { MyEVA } \\
\text { Mobile }\end{array}$ & $\begin{array}{l}\text { An offline mobile assisted language learning application } \\
\text { system, 'My English Vocabulary Assistant mobile } \\
\text { edition' (MYEVA Mobile) was developed to engage } \\
\text { mixed-modality vocabulary learning to improve their } \\
\text { vocabulary. }\end{array}$ & Not Available & $\begin{array}{l}\text { Logfile obtained } \\
\text { from log } \\
\text { analyzer server } \\
\text { to analyze the } \\
\text { results }\end{array}$ \\
\hline & [41] & 2016 & AKWIC & $\begin{array}{l}\text { In the context of academic English, a mobile data-driven } \\
\text { learning (DDL) experiment was discussed by designing }\end{array}$ & Not Available & $\begin{array}{l}\text { Automatic } \\
\text { logging to }\end{array}$ \\
\hline
\end{tabular}




\begin{tabular}{|c|c|c|c|c|c|c|}
\hline & & & & $\begin{array}{l}\text { and developing an application' AKWIC (academic key } \\
\text { words in context)' for voluntary participants. }\end{array}$ & & $\begin{array}{l}\text { gather data from } \\
\text { the application }\end{array}$ \\
\hline & {$[45]$} & 2018 & $\begin{array}{l}\text { WhatsApp and } \\
\text { internet search } \\
\text { engines } \\
\text { (Google) }\end{array}$ & $\begin{array}{l}\text { Students used mobile applications like WhatsApp and } \\
\text { Internet search engine (Google) to access reading and } \\
\text { interaction materials with peers and instructors outside } \\
\text { the class. }\end{array}$ & Not Available & $\begin{array}{l}\text { The data is } \\
\text { taken from the } \\
\text { application\& } \\
\text { manually is } \\
\text { considered one } \\
\text { unit. }\end{array}$ \\
\hline & {$[58]$} & 2019 & $\begin{array}{l}\text { Save the } \\
\text { princess with } \\
\text { Teddy }\end{array}$ & $\begin{array}{l}\text { A mobile-based gaming approach for English grammar } \\
\text { and vocabulary learning 'Save the princess with Teddy' } \\
\text { was developed and analyzed students' learning } \\
\text { achievement with gameplay at different levels. }\end{array}$ & Not Available & Not Available \\
\hline \multirow{8}{*}{ 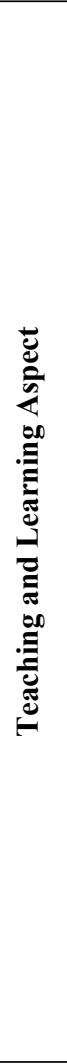 } & {$[2]$} & 2012 & $\begin{array}{l}\text { Mobagogy \& } \\
\text { The Bird in the } \\
\text { Hand }\end{array}$ & $\begin{array}{l}\text { 'Mobagogy' a professional learning community of } \\
\text { academicians to investigate to use of mobile technologies } \\
\text { in learning and teaching whereas, 'The bird in the Hand' } \\
\text { initiative by UK to examine the experience of trainee and } \\
\text { newly qualified teachers by providing them smartphones } \\
\text { to use in their offices and teaching schools to enhance } \\
\text { professional practices. }\end{array}$ & $\begin{array}{l}\text { Mobagogy developed by } \\
\text { Australian University, } \\
\text { UK sponsors the bird in } \\
\text { the Hand }\end{array}$ & Not Available \\
\hline & {$[35]$} & 2016 & $\begin{array}{l}\text { English Fun } \\
\text { Dubbing }\end{array}$ & $\begin{array}{l}\text { To evaluate mobile applications' benefits, an application } \\
\text { 'English Fun Dubbing' is designed for the oral practice of } \\
\text { English for its users. }\end{array}$ & $\begin{array}{l}\text { Developed by a Chinese } \\
\text { Sci-Tech company }\end{array}$ & Not Available \\
\hline & [39] & 2017 & LINE app & $\begin{array}{l}\text { LINE app, an application that was used to investigate the } \\
\text { teaching English for specific purpose (ESP) effects on } \\
\text { Business Language Testing Service (BULATS) after the } \\
\text { class. }\end{array}$ & Not Available & Not Available \\
\hline & {$[50]$} & 2018 & VocUp & $\begin{array}{l}\text { To enhance English vocabulary teaching and learning, a } \\
\text { mobile-based application 'VocUp' was designed and } \\
\text { implemented. }\end{array}$ & $\begin{array}{l}\text { Evaluated by external } \\
\text { parties }\end{array}$ & Not Available \\
\hline & {$[51]$} & 2017 & WhatsApp & $\begin{array}{l}\text { A mobile application, 'WhatsApp' was used in this study } \\
\text { to examine the efficiency of the teaching of } 40 \text { phrases. }\end{array}$ & Not Available & Not Available \\
\hline & {$[55]$} & 2020 & $\begin{array}{l}\text { Anglictina } \\
\text { (English) } \\
\text { TODAY } \\
\end{array}$ & $\begin{array}{l}\text { An application Anglictina (English) TODAY was } \\
\text { developed to help pupils prepare for final exams by } \\
\text { learning from anywhere at any time. }\end{array}$ & Not Available & Not Available \\
\hline & [59] & 2012 & $\begin{array}{l}\text { Grammar } \\
\text { Grabber }\end{array}$ & $\begin{array}{l}\text { To evaluate grammar at the school level, an online } \\
\text { assessment tool, 'Grammar Grabber' was discussed in this } \\
\text { study. }\end{array}$ & Not Available & $\begin{array}{l}\text { Log files of user } \\
\text { accounts }\end{array}$ \\
\hline & {$[61]$} & 2020 & $\begin{array}{l}\text { Literacy and } \\
\text { Numeracy } \\
\text { Drive }\end{array}$ & $\begin{array}{l}\text { An application, 'Literacy and Numeracy Drive' to teach } \\
\text { and learn languages at the school level, was discussed. } \\
\text { This application provided some practice and then some } \\
\text { assessment exercises for the English language. }\end{array}$ & Not Available & Not Available \\
\hline \multirow{5}{*}{ 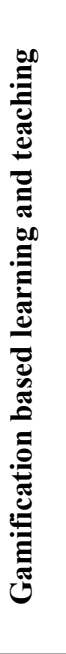 } & {$[5]$} & 2011 & $\begin{array}{c}\text { MEL } \\
\text { Application } \\
\text { (Serious Game) }\end{array}$ & $\begin{array}{l}\text { A serious game, 'MEL application,' developed in which } \\
25 \text { animals from five continents (Asia, South-America, } \\
\text { Africa, Oceania, and North-America) were involved and } \\
\text { played during the visit to the zoo home. }\end{array}$ & $\begin{array}{l}\text { The pre-test and Post-test } \\
\text { consisted of a vocabulary } \\
\text { test to measure active and } \\
\text { passive word knowledge. }\end{array}$ & Not Available \\
\hline & {$[8]$} & 2011 & Mentira & $\begin{array}{l}\text { Augmented reality game-based language learning of } \\
\text { Spanish in Southwestern US explores foreign and second } \\
\text { language learning's benefits and complexities. }\end{array}$ & $\begin{array}{l}\text { The interview was taken } \\
\text { after playing this game by } \\
\text { the players }\end{array}$ & Not Available \\
\hline & {$[10]$} & 2014 & $\begin{array}{l}\text { Mobile English } \\
\text { Learning2 } \\
\text { (MEL2) (Game } \\
\text { features added) }\end{array}$ & $\begin{array}{l}\text { To investigate a mobile English learning application that } \\
\text { would be supplement and support for learning English at } \\
\text { school was adopted for the study by enhancing game } \\
\text { features. }\end{array}$ & Adapted from Literature & $\begin{array}{l}\text { An online } \\
\text { database to store } \\
\text { data }\end{array}$ \\
\hline & {$[20]$} & 2018 & $\begin{array}{c}\text { English } \\
\text { Vocabulary } \\
\text { Practice System } \\
\text { Game } \\
\end{array}$ & $\begin{array}{l}\text { The mobile-based English Vocabulary system for } \\
\text { practice was designed and developed to provide students } \\
\text { with assistance to review, proficiency, and practice in the } \\
\text { class and after the class. }\end{array}$ & $\begin{array}{l}\text { This game system was } \\
\text { developed based on the } \\
\text { ARCS model. }\end{array}$ & Not Available \\
\hline & {$[26]$} & 2014 & $\begin{array}{l}\text { Idiomobile } \\
\text { (Game for } \\
\text { idioms) }\end{array}$ & $\begin{array}{l}\text { 'Idiomobile' a mobile-based game that was made } \\
\text { available for specific handsets based on the knowledge of } \\
\text { using idiomatic expressions. }\end{array}$ & Not Available & $\begin{array}{l}\text { Data collected } \\
\text { from phones }\end{array}$ \\
\hline
\end{tabular}




\begin{tabular}{|c|c|c|c|c|c|}
\hline$[28]$ & 2017 & $\begin{array}{l}\text { Game-based } \\
\text { Happy English } \\
\text { Learning } \\
\text { System } \\
\end{array}$ & $\begin{array}{l}\text { A game-based system, 'Happy English Learning System', } \\
\text { in which learning material was integrated to experiment } \\
\text { to see the learner's motivation for achievement. }\end{array}$ & Not Available & Not Available \\
\hline [46] & 2019 & $\begin{array}{c}\text { Excel@English } \\
\text { PolyU } \\
\text { (Alphabet vs. } \\
\text { Aliens and } \\
\text { Books vs. } \\
\text { Brains@PolyU } \\
\text { ) } \\
\end{array}$ & $\begin{array}{l}\text { A game-based applications Excel@EnglishPolyU, } \\
\text { Alphabet vs. Aliens, and Books vs. Brains@PolyU, in } \\
\text { which business vocabulary after completing level } \\
\text { challenges could acquire by the learners. }\end{array}$ & Not Available & Not Available \\
\hline$[47]$ & 2019 & $\begin{array}{c}\text { PHONE } \\
\text { Words }\end{array}$ & $\begin{array}{l}\text { An application 'PHONE Words' was developed for } \\
\text { vocabulary learning, designed with game functions and } \\
\text { without game functions to investigate the perceptions and } \\
\text { measure learners' learning performance. }\end{array}$ & Not Available & $\begin{array}{l}\text { Log File from } \\
\text { the DB server in } \\
\text { which usage } \\
\text { behavior is } \\
\text { recorded. }\end{array}$ \\
\hline$[52]$ & 2013 & Word Score & $\begin{array}{l}\text { A serious online game was designed to extend the } \\
\text { students' vocabulary in primary school was discussed in } \\
\text { this study. }\end{array}$ & $\begin{array}{l}\text { This game was part of the } \\
\text { national project } \\
\text { 'Educational } \quad \text { Time } \\
\text { Extension (ETE)'. }\end{array}$ & Not Available \\
\hline$[56]$ & 2019 & SOS Table & $\begin{array}{l}\text { 'SOS Table,' a mobile-based game application, was } \\
\text { designed and developed to repeat tenses, high-frequency } \\
\text { words, and sentence string. }\end{array}$ & Not Available & Not Available \\
\hline
\end{tabular}




\section{Table $\mathbf{1 3}$ (on next page)}

Findings of the reviewed studies for content 
Table 13: Findings of the reviewed studies for content.

\begin{tabular}{|c|c|c|c|c|}
\hline Criterion for content & $\begin{array}{l}\text { Year/ } \\
\text { Grade }\end{array}$ & Ref. & $\begin{array}{c}\text { Evaluation } \\
\text { Method }\end{array}$ & Findings \\
\hline Readiness of M-learning & $\begin{array}{c}2012 \\
\text { (college) }\end{array}$ & {$[1]$} & $\begin{array}{c}\text { Structural } \\
\text { Equation } \\
\text { Modeling (SEM) }\end{array}$ & $\begin{array}{l}\text { The participants were undergraduate students at a } \\
\text { large, public university in which students were } \\
\text { enrolled in a subject, "Computing and Information } \\
\text { Technology (CIT)" which was the core curriculum } \\
\text { subject required by all the students. }\end{array}$ \\
\hline Reading annotation & $\begin{array}{c}2013 \\
\text { (School) }\end{array}$ & {$[6]$} & $\begin{array}{l}\text { Quasi-Experiment } \\
\text { with the } \\
\text { Technology } \\
\text { Acceptance Model } \\
\text { and Cognitive } \\
\text { Load } \\
\text { questionnaire } \\
\end{array}$ & $\begin{array}{l}\text { Personalized recommended learning materials } \\
\text { with reading annotation services were provided to } \\
\text { the students by analyzing profiles and portfolios } \\
\text { using a developed adaptive learning system. The } \\
\text { reading material was categorized into three } \\
\text { difficulty levels: Elementary, Intermediate, and } \\
\text { Intermediate-High level. }\end{array}$ \\
\hline $\begin{array}{l}\text { Written and Audio-Visual } \\
\text { material }\end{array}$ & $\begin{array}{c}2016 \\
\text { (University) }\end{array}$ & [19] & $\begin{array}{l}\text { Partial least square } \\
\text { structural equation } \\
\text { modeling }\end{array}$ & $\begin{array}{l}\text { Multimedia learning material in written and audio- } \\
\text { visual form was provided using the CoLaLe app to } \\
\text { enhance the vocabulary learning experience. The } \\
\text { content was delivered using the app according to } \\
\text { the relevant current position of the user. Words and } \\
\text { pictures were useful for learners to learn } \\
\text { vocabulary by solving word pair quizzes. }\end{array}$ \\
\hline $\begin{array}{l}\text { Reading and Listening } \\
\text { material }\end{array}$ & $\begin{array}{c}2013 \\
\text { (School) }\end{array}$ & {$[24]$} & $\begin{array}{l}\text { One-group post- } \\
\text { test design }\end{array}$ & $\begin{array}{l}\text { The content in Mebook was broad and varied, } \\
\text { including current issues related to education, } \\
\text { economy, environment, social, politics, } \\
\text { technology, etc. For English learning, the topic } \\
\text { area covered was: speaking, listening, reading, and } \\
\text { vocabulary. }\end{array}$ \\
\hline $\begin{array}{l}\text { Idioms collected from Books } \\
\text { and Websites }\end{array}$ & $\begin{array}{c}2014 \\
\text { (University) }\end{array}$ & {$[26]$} & $\begin{array}{l}\text { The questionnaire, } \\
\text { Application usage, } \\
\text { and Exit Interview }\end{array}$ & $\begin{array}{l}\text { Teaching the most popular idioms, content } \\
\text { relevant to idioms and collocations was collected } \\
\text { for application from books and websites. The } \\
\text { idioms appeared in most websites, or books were } \\
\text { selected into the application to teach ESLs. }\end{array}$ \\
\hline $\begin{array}{l}\text { Multimedia content added } \\
\text { by the user }\end{array}$ & $\begin{array}{c}2013 \\
\text { (Other) }\end{array}$ & {$[27]$} & Conceptual Paper & $\begin{array}{l}\text { A language learning application 'LingoBee' was } \\
\text { designed for the cooperative creation of } \\
\text { multimedia content by adding it to new vocabulary } \\
\text { by the users. It was stored on the device of the users } \\
\text { then uploaded to the cloud provided by the } \\
\text { application. The content could be viewed or } \\
\text { browsed LingoBee repository by sorting it } \\
\text { chronologically or alphabetically. }\end{array}$ \\
\hline $\begin{array}{c}\text { Phonics, Symbols, } \\
\text { Vocabulary, and Sentence } \\
\text { pattern }\end{array}$ & $\begin{array}{c}2017 \\
\text { (School) }\end{array}$ & {$[28]$} & $\begin{array}{l}\text { Quasi- } \\
\text { experimental } \\
\text { method }\end{array}$ & $\begin{array}{l}\text { The English subject's curriculum consisted of } \\
\text { phonetic symbols, alphabet, grammar, phrases, } \\
\text { vocabulary, and sentence patterns. Pupils could use } \\
\text { the HELS application to review the content and } \\
\text { share the content prepared by them in the class and } \\
\text { social media (i.e., Facebook). }\end{array}$ \\
\hline Vocabulary acquisition & $\begin{array}{c}2019 \\
\text { (University) }\end{array}$ & [32] & $\begin{array}{c}\text { Dashboard, } \\
\text { Questionnaire, and } \\
\text { Interview }\end{array}$ & $\begin{array}{l}\text { The course content in application 'Duolingo' } \\
\text { focused on various subjects, specifically } \\
\text { vocabulary acquisition, by learning nearly } 2000 \\
\text { words. The application's delivery techniques were } \\
\text { translation from source to target language of users, } \\
\text { choosing the right translated phrases, paring of } \\
\text { words from languages, flashcard practicing, and } \\
\text { translation of unknown words. }\end{array}$ \\
\hline Vocabulary teaching & $\begin{array}{c}2017 \\
\text { (University) }\end{array}$ & {$[40]$} & $\begin{array}{l}\text { Questionnaire, } \\
\text { Pretest, Posttest, } \\
\text { Log upload }\end{array}$ & $\begin{array}{l}\text { The content used in this study for vocabulary } \\
\text { teaching suitable for 'Test of English for } \\
\text { International Communication (TOEIC), which is a } \\
\text { standardized test used in Taiwan. Fifty words were } \\
\text { taken for vocabulary was chosen from TOEIC, } \\
\text { including different difficulty levels. }\end{array}$ \\
\hline
\end{tabular}




\begin{tabular}{|c|c|c|c|c|}
\hline $\begin{array}{c}\text { Animation and Videos for } \\
\text { learning }\end{array}$ & $\begin{array}{c}2016 \\
\text { (University) }\end{array}$ & {$[35]$} & $\begin{array}{c}\text { Anonymous online } \\
\text { Questionnaire }\end{array}$ & $\begin{array}{l}\text { An application designed by a Chinese Sci-Tech } \\
\text { company to assist in English practice orally. It } \\
\text { provided rich learning material of animations, } \\
\text { movies, short videos, songs, and textbooks with } \\
\text { English speakers speaking for different age group } \\
\text { students. }\end{array}$ \\
\hline Vocabulary learning & $\begin{array}{c}2018 \\
\text { (University) }\end{array}$ & {$[50]$} & Interviews & $\begin{array}{l}\text { For the vocabulary test, 'Word Capsules (short } \\
\text { vocabulary tests)' was developed. Words } \\
\text { (content) were selected from } 10,000 \text { words for the } \\
\text { test, who gripped numerous words in English with } \\
\text { a vast vocabulary and can survive with studying } \\
\text { challenges at a higher level in English. }\end{array}$ \\
\hline $\begin{array}{l}\text { Vocabulary and Phrases } \\
\text { learning }\end{array}$ & $\begin{array}{c}2020 \\
\text { (University) }\end{array}$ & {$[55]$} & Questionnaire & $\begin{array}{l}\text { Practicing and retaining new phrases and words } \\
\text { while learning English, ten lessons of vocabulary } \\
\text { and ten lessons of phrases were adopted, and } \\
\text { pupils have to translate to English from the native } \\
\text { language. }\end{array}$ \\
\hline Pictures and Videos & $\begin{array}{c}2011 \\
\text { (School) }\end{array}$ & {$[5]$} & $\begin{array}{l}\text { Pre-test and Post- } \\
\text { test }\end{array}$ & $\begin{array}{l}\text { Pictures and videos to learn about zoo animals } \\
\text { from five continents. }\end{array}$ \\
\hline Classroom curriculum & $\begin{array}{c}2011 \\
\text { (University) }\end{array}$ & {$[8]$} & Interviews & $\begin{array}{l}\text { To learn Spanish from an Augmented reality (AR) } \\
\text { game-based language learning tool, gameplay, } \\
\text { narrative, setting, and curriculum were added. The } \\
\text { classroom curriculum was adopted for the game } \\
\text { for the three-to-four-week timeframe. }\end{array}$ \\
\hline Vocabulary practicing & $\begin{array}{c}2018 \\
\text { (University) }\end{array}$ & {$[20]$} & Questionnaire & $\begin{array}{l}\text { A game-based English vocabulary practice system } \\
\text { in which the vocabulary presentation model } \\
\text { combined learning content with difficult } \\
\text { vocabulary levels. }\end{array}$ \\
\hline Vocabulary learning & $\begin{array}{c}2019 \\
\text { (University) }\end{array}$ & {$[47]$} & $\begin{array}{l}\text { Questionnaire and } \\
\text { Interviews }\end{array}$ & $\begin{array}{l}\text { For vocabulary learning using MEVLA-GF, } \\
\text { interviewees' perception identified gamified } \\
\text { design, interface design, and content design. The } \\
\text { interface and gamified design efficiently be used, } \\
\text { and content should also satisfy the learners' needs } \\
\text { for different purposes and at the level for } \\
\text { vocabulary learning. }\end{array}$ \\
\hline $\begin{array}{c}\text { Vocabulary, Sentences, } \\
\text { Grammar }\end{array}$ & $\begin{array}{c}2019 \\
(\text { School })\end{array}$ & {$[58]$} & $\begin{array}{c}\text { Quasi- } \\
\text { experimental }\end{array}$ & $\begin{array}{l}\text { Learning material consisted of vocabulary, } \\
\text { sentence examples, grammar examples, and } \\
\text { grammar concept mapping for English games in } \\
\text { elementary school. The purpose was to make a } \\
\text { strong foundation of English grammar and } \\
\text { enhance its knowledge with the understandability } \\
\text { of relationships between concepts. }\end{array}$ \\
\hline
\end{tabular}




\section{Table 14(on next page)}

Research Methodologies adopted by studies 
Table. 14 Research Methodologies adopted by studies

\begin{tabular}{|c|c|c|c|}
\hline Methodology & Instrument & Ref. sources & Total \\
\hline Quantitative & Questionnaire & $\begin{array}{l}{[1][3][4][5][6][7][9][10][11][12][13][15]} \\
{[16][18][20][21][24][25][28][31][35][38]} \\
{[39][46][49][51][52][53][55][56][58][60]} \\
{[62]}\end{array}$ & 33 \\
\hline Qualitative & $\begin{array}{c}\text { Interview } \\
\text { Observation }\end{array}$ & {$[8][30][36][45][48][50]$} & 6 \\
\hline Mix Method & $\begin{array}{l}\text { Questionnaire } \\
\text { Interview } \\
\text { Observation } \\
\end{array}$ & $\begin{array}{l}{[14][22][23][26][29][32][33][34][40][41]} \\
{[42][43][44][47][57][59][61][63]}\end{array}$ & 18 \\
\hline Other & $\begin{array}{c}\text { Discussion } \\
\text { Others }\end{array}$ & {$[17][19][27][37][54]$} & 5 \\
\hline
\end{tabular}




\section{Table $\mathbf{1 5}$ (on next page)}

Approaches used in Applications/Games of current studies 
Table 15. Approaches used in Applications/Games of current studies

\begin{tabular}{|c|c|c|c|c|c|}
\hline $\begin{array}{c}\text { Item } \\
\text { No. }\end{array}$ & Game / Application & Evaluation Method & Approach Measured & $\begin{array}{c}\text { Tool to } \\
\text { measure }\end{array}$ & Ref. \\
\hline 1 & $\begin{array}{l}\text { Mobagogy \& The Bird in } \\
\text { the Hand }\end{array}$ & $\begin{array}{l}\text { Developed by Australian } \\
\text { University and UK }\end{array}$ & Pedagogy & - & {$[2]$} \\
\hline 2 & $\begin{array}{l}\text { MEL Application (Serious } \\
\text { Game) }\end{array}$ & $\begin{array}{l}\text { The pre-test and Post-test } \\
\text { consisted of a vocabulary } \\
\text { test to measure active and } \\
\text { passive word knowledge. }\end{array}$ & - & Questionnaire & [5] \\
\hline 3 & Vocabulary and Annotation & Literature Review & - & Questionnaire & [6] \\
\hline 4 & Mentira & $\begin{array}{l}\text { Interview was taken after } \\
\text { playing this game by the } \\
\text { players }\end{array}$ & - & $\begin{array}{l}\text { Interview and } \\
\text { Observation }\end{array}$ & [8] \\
\hline 5 & 'Fetion' SMS text message & - & - & - & [9] \\
\hline 6 & $\begin{array}{l}\text { Mobile English Learning2 } \\
\text { (MEL2) (Game features } \\
\text { added) }\end{array}$ & Adopted from Literature & - & - & {$[10]$} \\
\hline 7 & Mobile Learning Tool & Literature Review & Motivation & Questionnaire & [11] \\
\hline 8 & $\begin{array}{l}\text { Raz-kids (Online reading } \\
\text { tool) }\end{array}$ & A to $\mathrm{Z}$ (Company) & Perception & Questionnaire & [12] \\
\hline 9 & $\begin{array}{l}\text { Automatic Speech } \\
\text { Recognition (ASR) }\end{array}$ & Five native French speakers & - & - & {$[16]$} \\
\hline 10 & CoLaLe app & A Short Video & $\begin{array}{l}\text { Perceived usefulness, } \\
\text { Perceived Ease of use }\end{array}$ & - & [19] \\
\hline 11 & $\begin{array}{l}\text { English Vocabulary Practice } \\
\text { System Game }\end{array}$ & $\begin{array}{l}\text { This game system } \\
\text { developed on the basis of } \\
\text { ARCS model. }\end{array}$ & $\begin{array}{l}\text { Effectiveness and } \\
\text { Motivation }\end{array}$ & Questionnaire & [20] \\
\hline 12 & Mebook & 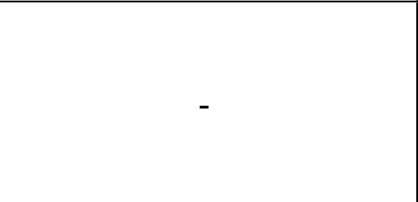 & $\begin{array}{l}\text { Perceived usefulness, } \\
\text { Perceived } \\
\text { convenience, curiosity, } \\
\text { and continuance } \\
\text { intention }\end{array}$ & Questionnaire & [24] \\
\hline 13 & $\begin{array}{l}\text { Idiomobile } \\
\text { (Game for idioms) }\end{array}$ & - & Attitude, Motivation & $\begin{array}{l}\text { Questionnaire, } \\
\text { Interviews }\end{array}$ & [26] \\
\hline 14 & LingoBee & User Studies & $\begin{array}{l}\text { Motivation and } \\
\text { Achievement }\end{array}$ & Questionnaire & [27] \\
\hline 15 & $\begin{array}{l}\text { Game-based Happy English } \\
\text { Learning System }\end{array}$ & - & $\begin{array}{l}\text { Motivation, } \\
\text { Effectiveness }\end{array}$ & Questionnaire & [28] \\
\hline 16 & Duolingo & $\begin{array}{ll}\text { Free application } & \text { for } \\
\text { Android and iOS } & \\
\end{array}$ & Self-directed learning & $\begin{array}{l}\text { Questionnaire, } \\
\text { Interviews }\end{array}$ & [32] \\
\hline 17 & Duolingo & $\begin{array}{ll}\text { Free application } & \text { for } \\
\text { Android and iOS } & \\
\end{array}$ & Attitude & Questionnaire & [34] \\
\hline 18 & English Fun Dubbing & $\begin{array}{l}\text { Developed by Chinese Sci- } \\
\text { Tech company }\end{array}$ & - & Questionnaire & [35] \\
\hline 19 & English Practice & Online evaluation & Behavior pattern & - & [37] \\
\hline 20 & $\begin{array}{l}\text { Mobile-assisted listening } \\
\text { application }\end{array}$ & Pilot study & Effectiveness & Questionnaire & [38] \\
\hline 21 & LINE app & - & Satisfaction, Attitude & $\begin{array}{l}\text { Questionnaire, } \\
\text { Classroom } \\
\text { observation }\end{array}$ & [39] \\
\hline 22 & MyEVA Mobile & Literature Review & $\begin{array}{l}\text { Attitude, } \\
\text { Achievements, } \\
\text { Learning behavior }\end{array}$ & Questionnaire & [40] \\
\hline 23 & AKWIC & - & Attitude, Effectiveness & Questionnaire, & [41] \\
\hline
\end{tabular}




\begin{tabular}{|c|c|c|c|c|c|}
\hline & & & & Interviews & \\
\hline 24 & $\begin{array}{l}\text { WhatsApp and internet } \\
\text { search engines (Google) }\end{array}$ & - & Learner's autonomy & Interviews & [45] \\
\hline 25 & $\begin{array}{l}\text { Excel@EnglishPolyU } \\
\text { (Alphabet vs. Aliens and } \\
\text { Books vs. Brains@PolyU) }\end{array}$ & - & - & $\begin{array}{c}\text { Online } \\
\text { questionnaire }\end{array}$ & [46] \\
\hline 26 & PHONE Words & - & Perception & $\begin{array}{l}\text { Questionnaire, } \\
\text { Interviews }\end{array}$ & [47] \\
\hline 27 & VocUp & $\begin{array}{l}\text { Evaluated by external } \\
\text { parties }\end{array}$ & $\begin{array}{l}\text { Usability, Scalability, } \\
\text { Reliability, and } \\
\text { Flexibility }\end{array}$ & Interview & [50] \\
\hline 28 & WhatsApp & - & Efficiency & - & [51] \\
\hline 29 & Word Score & $\begin{array}{l}\text { This game was part of the } \\
\text { national } \\
\text { 'Educational } \\
\text { Extension (ETE)'. }\end{array}$ & $\begin{array}{l}\text { Motivation, } \\
\text { Effectiveness }\end{array}$ & $\begin{array}{l}\text { Questionnaire, } \\
\text { Interviews }\end{array}$ & [52] \\
\hline 30 & $\begin{array}{l}\text { Anglictina (English) } \\
\text { TODAY }\end{array}$ & - & Perception & Questionnaire & [55] \\
\hline 31 & SOS Table & - & Effectiveness & $\begin{array}{l}\text { Questionnaire } \\
\text { and Interviews }\end{array}$ & [56] \\
\hline 32 & $\begin{array}{l}\text { Save the princess with } \\
\text { Teddy }\end{array}$ & Literature Review & - & Questionnaire & [58] \\
\hline 33 & Grammar Grabber & - & Affordance & $\begin{array}{l}\text { Questionnaire, } \\
\text { Interviews }\end{array}$ & [59] \\
\hline 34 & $\begin{array}{l}\text { Literacy and Numeracy } \\
\text { Drive }\end{array}$ & - & $\begin{array}{l}\text { Perceived usefulness, } \\
\text { Ease of Use }\end{array}$ & $\begin{array}{l}\text { Questionnaire, } \\
\text { Interviews }\end{array}$ & [61] \\
\hline
\end{tabular}

2 


\section{Table $\mathbf{1 6}$ (on next page)}

Tools used for analysis in current studies 
1

Table 16. Tools used for analysis in current studies

\begin{tabular}{|l|l|c|}
\hline \multicolumn{1}{|c|}{ Study Ref. } & \multicolumn{1}{|c|}{ Tool } & Total \\
\hline $\begin{array}{l}|c| \\
{[3][4][5][6][7][9][10][11][12][13][14]}\end{array}$ & \\
$\begin{array}{l}{[29][32][33][34][38][39][40][42][43]} \\
{[44][47][51][52][56][58][60][61][62]}\end{array}$ & $\begin{array}{l}\text { Statistical Package for Social } \\
{[63]}\end{array}$ & Sciences (SPSS) \\
\hline$[21][24]$ & & \\
\hline$[30][41]$ & Partial Least Squares (PLS) & 2 \\
\hline$[55][59]$ & Nvivo & 2 \\
\hline$[1]$ & Manually & 2 \\
\hline$[35]$ & Mplus 6.11 & 1 \\
\hline$[36]$ & Wenjuan Wang & 1 \\
\hline$[37]$ & (www.wenjuan.com) & 1 \\
\hline$[45]$ & Facets 3.62 & 1 \\
\hline$[46]$ & Google Firebase analytics tool & 1 \\
\hline$[53]$ & Notes taking & 1 \\
\hline$[2][8][17][19][27][31][48][49][50][54]$ & Online tool & 1 \\
\hline 55$]$ & Google Sheet & 11 \\
\hline
\end{tabular}




\section{Table 17 (on next page)}

Mobile Application and Gamified Applications 
Table 17. Mobile Application and Gamified Applications

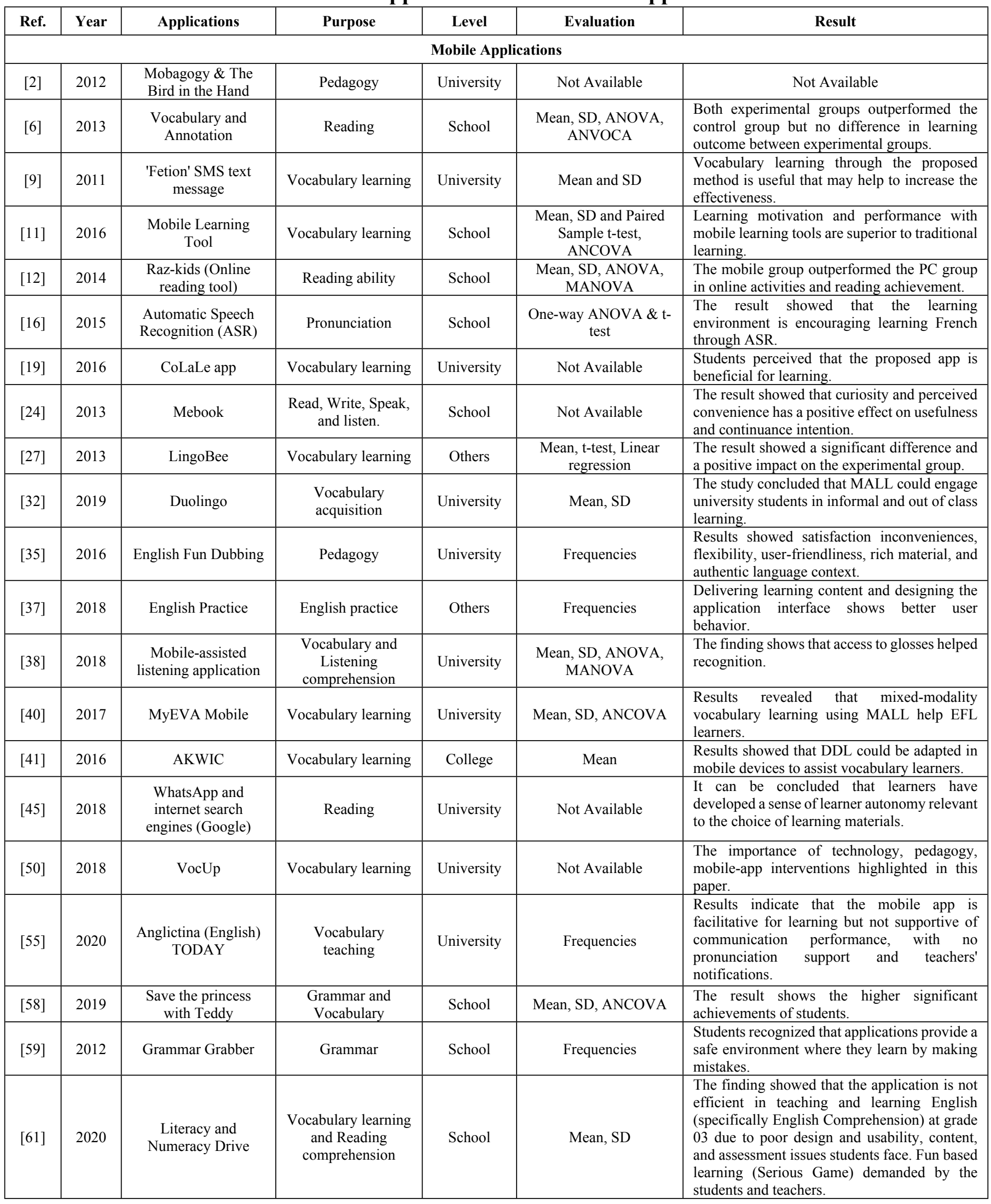




\begin{tabular}{|c|c|c|c|c|c|c|}
\hline \multicolumn{7}{|c|}{ Gamified Apps (Serious Game) } \\
\hline [5] & 2011 & MEL Application & Vocabulary learning & School & Paired T-Test & $\begin{array}{l}\text { The results revealed that students are motivated } \\
\text { to use the application in their spare time. }\end{array}$ \\
\hline [10] & 2014 & $\begin{array}{l}\text { Mobile English } \\
\text { Learning2 (MEL2) } \\
\text { (Game features } \\
\text { added) }\end{array}$ & Vocabulary learning & School & $\begin{array}{l}\text { MANOVA, ANCOVA, } \\
\text { and Correlation }\end{array}$ & $\begin{array}{l}\text { The results presented indicate that the students } \\
\text { who worked with MEL-enhanced outperform } \\
\text { the children who used MEL-original. }\end{array}$ \\
\hline [20] & 2018 & $\begin{array}{l}\text { English Vocabulary } \\
\text { Practice System } \\
\text { Game }\end{array}$ & Vocabulary learning & University & Mean, SD, t-test & $\begin{array}{l}\text { The game-based vocabulary practice system } \\
\text { had higher learning effectiveness for students } \\
\text { with positive feedback. }\end{array}$ \\
\hline [26] & 2014 & $\begin{array}{l}\text { Idiomobile (Game for } \\
\text { idioms) }\end{array}$ & Idioms & University & Mean, Correlation & $\begin{array}{l}\text { Results showed that participants have positive } \\
\text { attitudes toward the use of mobile technology } \\
\text { in language learning. }\end{array}$ \\
\hline [28] & 2017 & $\begin{array}{l}\text { Game-based Happy } \\
\text { English Learning } \\
\text { System }\end{array}$ & $\begin{array}{l}\text { Vocabulary, } \\
\text { Grammar, Sentence } \\
\text { Structure }\end{array}$ & School & $\begin{array}{l}\text { Mean, SD, Paired- } \\
\text { sample t-test, and } \\
\text { multiple linear } \\
\text { regression }\end{array}$ & $\begin{array}{l}\text { The results confirmed the positive effects of } \\
\text { encouraging students' achievement and } \\
\text { motivation for learning English. }\end{array}$ \\
\hline [46] & 2019 & $\begin{array}{l}\text { Excel@EnglishPolyU } \\
\text { (Alphabet vs. Aliens } \\
\text { and Books vs. } \\
\text { Brains@PolyU) }\end{array}$ & Vocabulary learning & University & Frequencies & $\begin{array}{l}\text { The study demonstrates that mobile gamified } \\
\text { educational programs are a productive avenue } \\
\text { for students to expand their business } \\
\text { vocabulary. }\end{array}$ \\
\hline [47] & 2019 & PHONE Words & Vocabulary learning & University & ANOVA, Frequencies & $\begin{array}{l}\text { The results showed that the performance in } \\
\text { vocabulary acquisition and retaining by the } \\
\text { experimental group was significantly higher. }\end{array}$ \\
\hline$[52]$ & 2013 & Word Score & Vocabulary learning & School & Mean, SD, t-test & $\begin{array}{l}\text { The results revealed teachers' and students' } \\
\text { positive experiences and significant } \\
\text { performance noted who played outside the } \\
\text { class time. }\end{array}$ \\
\hline$[56]$ & 2019 & SOS Table & $\begin{array}{l}\text { Tenses, Words, } \\
\text { Sentences }\end{array}$ & University & t-test, thematic analysis & $\begin{array}{l}\text { Results concluded that SOS Table is effective } \\
\text { and efficient. }\end{array}$ \\
\hline
\end{tabular}

